\title{
WestVirginiaUniversity
}

THE RESEARCH REPOSITORY @ WVU

Graduate Theses, Dissertations, and Problem Reports

2017

\section{A Delphi on Drowning Prevention Education Research}

Adam Bradley Katchmarchi

Follow this and additional works at: https://researchrepository.wvu.edu/etd

\section{Recommended Citation}

Katchmarchi, Adam Bradley, "A Delphi on Drowning Prevention Education Research" (2017). Graduate Theses, Dissertations, and Problem Reports. 5941.

https://researchrepository.wvu.edu/etd/5941

This Dissertation is protected by copyright and/or related rights. It has been brought to you by the The Research Repository @ WVU with permission from the rights-holder(s). You are free to use this Dissertation in any way that is permitted by the copyright and related rights legislation that applies to your use. For other uses you must obtain permission from the rights-holder(s) directly, unless additional rights are indicated by a Creative Commons license in the record and/ or on the work itself. This Dissertation has been accepted for inclusion in WVU Graduate Theses, Dissertations, and Problem Reports collection by an authorized administrator of The Research Repository @ WVU.

For more information, please contact researchrepository@mail.wvu.edu. 


\title{
A Delphi on Drowning Prevention Education Research
}

\author{
Adam Bradley Katchmarchi
}

\author{
Dissertation submitted to the \\ College of Physical Activity and Sport Sciences \\ at West Virginia University
}

in partial fulfillment of the requirements for the degree of

Doctor of Philosophy in Coaching and Teaching Studies

\author{
Andrea R. Taliaferro, Ph.D., Chair \\ Sean M. Bulger, Ed.D. \\ Emily M. Jones, Ph.D. \\ Gary J. Lhotsky, Ed.D.
}

Department of Coaching and Teaching Studies

\author{
Morgantown, West Virginia \\ 2017
}

Keywords: Delphi Technique, Drowning Prevention, Water Safety, Aquatics

Copyright 2017 Adam B. Katchmarchi 


\section{ABSTRACT \\ A Delphi on Drowning Prevention Education Research}

\section{Adam Bradley Katchmarchi}

Background: The World Health Organization's Global Drowning Report (2014) listed action steps to reduce drowning globally, with the last action step highlighting the need to address priority research with well-designed studies. While drowning injury and fatality rates remain largely unchanged in recent years in the United States, existing research has not developed a supportive foundation to identify priority research questions.

Purpose: The purpose of this study was to conduct a 3-round Delphi procedure to determine and prioritize future research questions associated with drowning prevention education in the United States.

Design \& Methodology: This research employed a 3-round Delphi procedure to (1) survey experts to brainstorm research questions needing to be addressed in the US and (2) seek a consensus on the rating of importance of each research question. Following consensus building, a qualitative cluster analysis was completed to highlight related themes among research questions.

Results: The results of the Delphi brainstorming resulted in 251 responses from 74 participants. After a qualitative content analysis, 101 research questioned emerged. Each research question was then rated by participants on a 7-point Likert scale of importance. Results of the Delphi reveled 9 priority $(\mu \geq 6)$ research questions and 75 moderately important $(\mu \geq 5)$ research questions. A qualitative cluster analysis revealed six distinct categories: (1) Education and Programming Effectiveness, (2) Lifeguard Protocols and Victim Recognition, (3) Aquatic Policy and Safety, (4) Surveillance Data, (5) Communication and Public Awareness, and (6) SocioCultural and Demographic Factors.

Conclusion: Results of this study give an in-depth analysis of priority research questions while providing framework for impactful future research studies and educational programming endeavors. 


\section{Dedication}

This work is dedicated to the family members, friends, and loved ones of all fatal and non-fatal drowning victims. I am lucky enough to have come into this work because of my love for aquatics and not because of a personal loss. When I first joined the National Drowning Prevention Alliance in 2010, I had no clue how many innocent people drowning effects. Having met countless families who have lost a child, mother, father, brother, sister, or friend to drowning has changed my perspective and my life's work. Your stories drive me every day to make a difference. NOT ONE MORE! 


\section{Acknowledgements}

Thank you to every single person who has allowed me the opportunity to be successful and meet all my educational goals. Your support, guidance, advice, expertise, and kindness does not go unnoticed.

First and foremost, I would like to thank the amazing team of academics, educators, professionals, and researchers that have taken the time and energy to guide me throughout my academic career. I would like to especially thank my committee chair, Dr. Andrea Taliaferro, for taking me under her wing and supporting my research line and career goals. The time, dedication, patience, and long hours Dr. Taliaferro committed to me over the past four years was truly a blessing and a gift. Dr. Taliaferro, thank you for never giving up on me, being a friend and a mentor, and not letting me jump off the WVU Coliseum! I have learned so much from you and I cannot thank you enough. I would also like to thank Dr. Emily Jones, Dr. Sean Bulger, and Dr. Robert Wiegand for their support, guidance, and commitment to me during my academic career in CPASS. Additionally, I would like to thank Dr. Gary Lhotsky and Dr. Luisa Velez for serving on my committee at various stages and supporting my secondary academic area of sport management. Lastly, I would also like to thank Dr. Valerie Wayda, Dr. Ryan Flett, and Dr. James Hannon for their special support and mentorship during my time in CPASS.

Secondly, I would like to give special thanks to Mr. Robert Ogoreuc for sparking my interest in aquatics and drowning prevention as a freshman at Slippery Rock University. Coach, without you none of this would have been possible! I am proud to not only have had the awesome experience of having you as a professor, but also now to work with you as a professional. Most of all, I am most glad to call you a true friend! Thank you!

Next, I would like to recognize an amazing team of professionals that I have been blessed to work with, be mentored by, and been supported by including the faculties at Slippery Rock University and Indiana University of Pennsylvania, the National Drowning Prevention Alliance's Board of Directors and so many more! Thank you for giving me the opportunities you have and believing in me at a young age! Also, a special thanks to my fellow doctoral students Hannah Kipfer, Tyler Goad, Lindsay Hammond, Jun Baek, Jamie Gilbert, Phil Liversedge, Karl Zang, Cory Brieoff, Brooke Towner, Adam Keath, Te Allar, Luciana Braga and so many more. You all helped me stay sane through this insane process. I can never thank you enough for your friendship! "From the outside looking in, you could never understand it; from the inside looking out, you could never explain it."

Lastly, I am so eternally thankful for my close friends and family! I don't even know where to begin. If it wasn't for you I would have never even dreamed of making it this far. Thank you for your unwavering support, lifelong guidance, unconditional love, and just always being there! Mom, Dad, Anne, Nanny, Danielle, Rachel, Abby, Kristen, John, Mr. Boone, and so many more. I could not have ever made it without you! 


\section{Table of Contents}

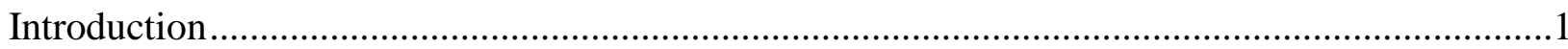

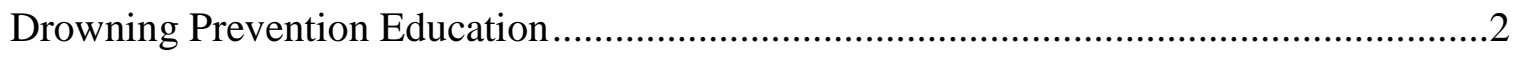

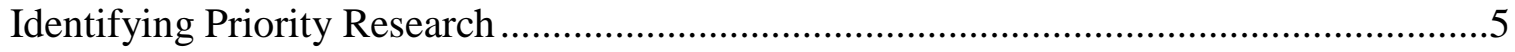

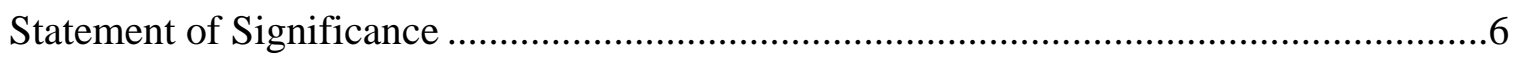

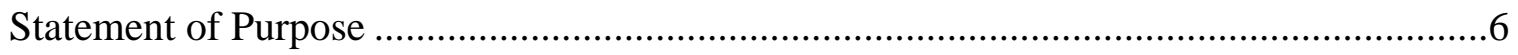

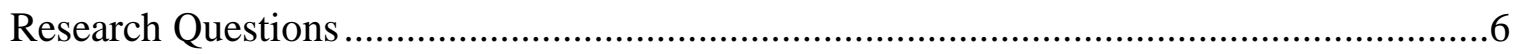

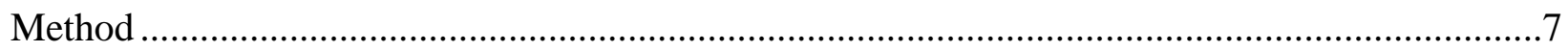

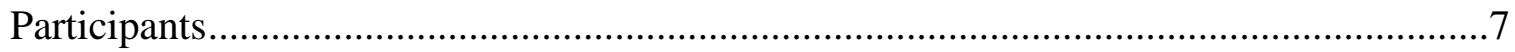

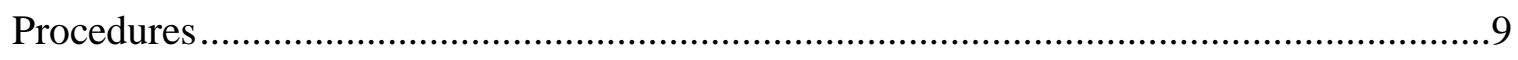

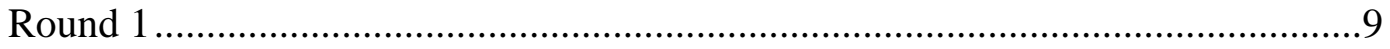

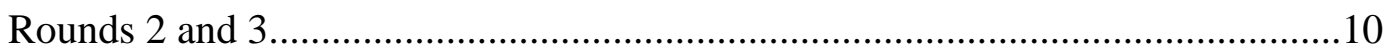

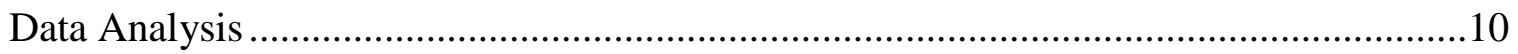

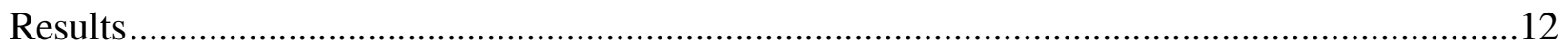

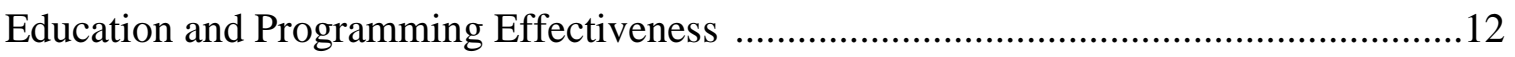

Lifeguard Protocols and Victim Recognition .....................................................13

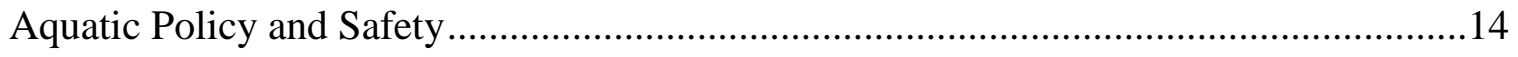

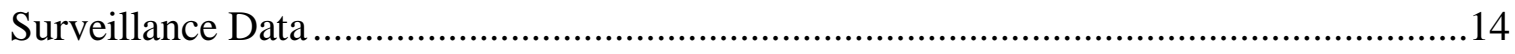

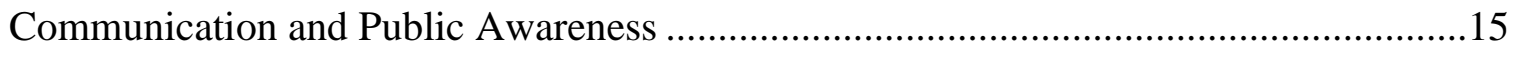

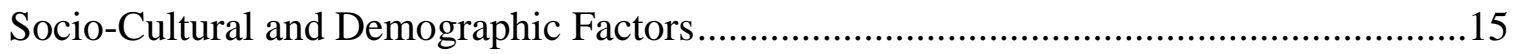

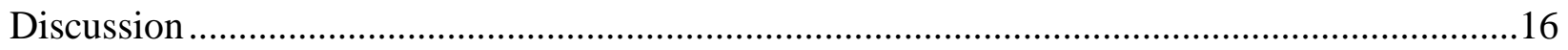

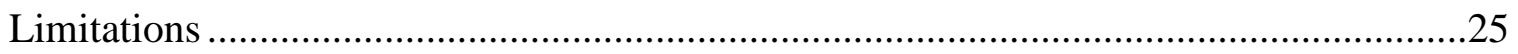

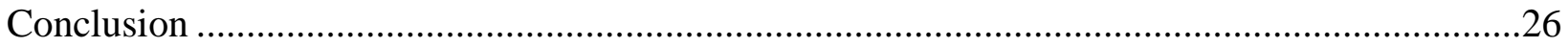




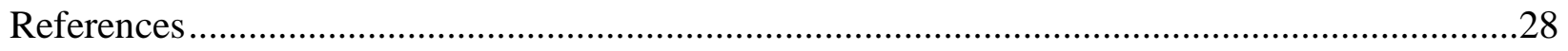

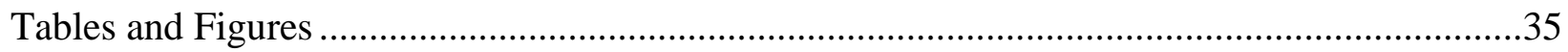

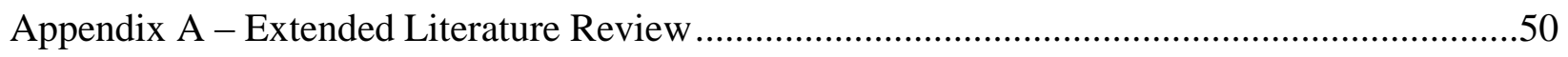

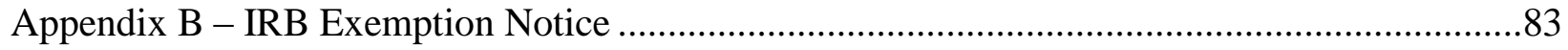

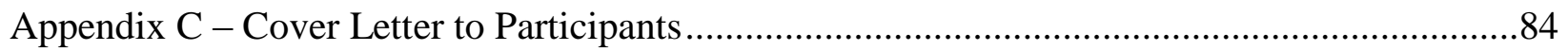

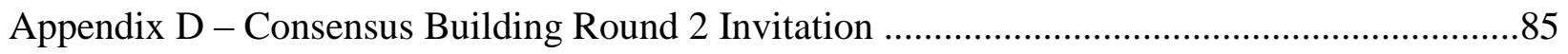

Appendix E - Consensus Building Round 3 Invitation ....................................................86

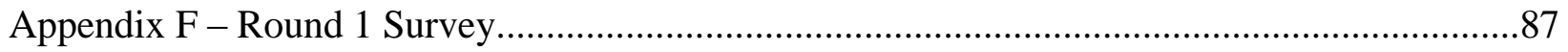

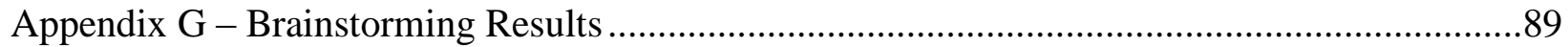

Appendix H - Consensus Building Round 2 Survey .....................................................99

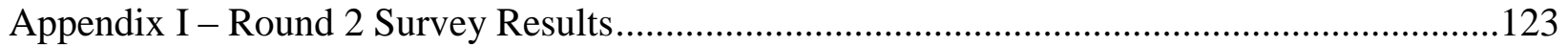

Appendix J - Consensus Building Round 3 Survey .........................................................137 


\section{List of Figures}

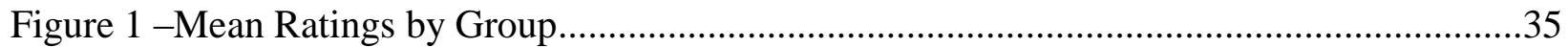

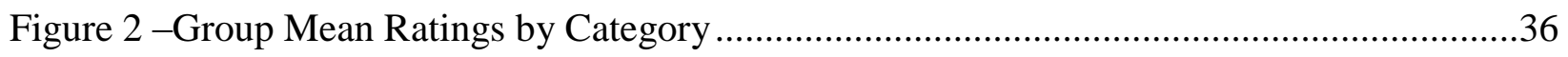

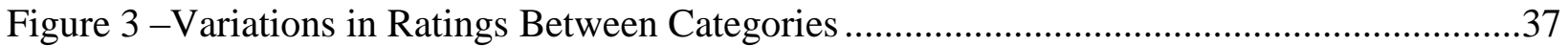




\section{List of Tables}

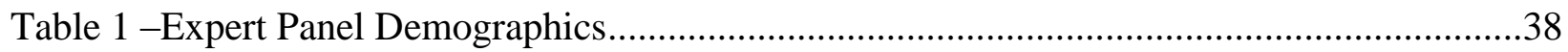

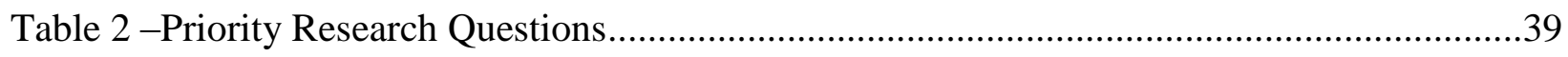

Table 3 -Education and Programming Effectiveness ......................................................40

Table 4 -Lifeguard Protocols and Victim Recognition .....................................................42

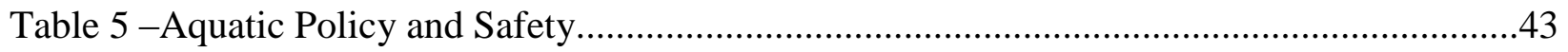

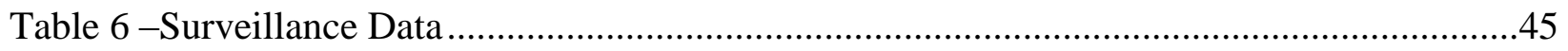

Table 7 -Communication and Public Awareness ................................................................4 47

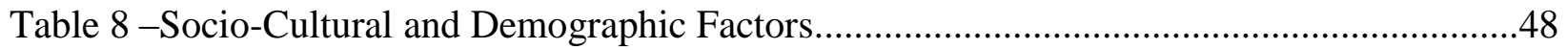

Table 9 -Literature Review - Potential Important Research Questions in Drowning .................82 


\section{Introduction}

Globally, drowning is one of the leading causes of unintentional injury-related death among all age ranges. According to the World Health Organization (WHO), drowning is estimated to claim the lives of 372,000 people each year, with over ninety percent (92\%) of these deaths occurring in low- and middle-income countries (WHO, 2014). Even though the United States (US), a high-income country, experiences a relatively lower number of drowning fatalities on an annual basis in comparison to low- and middle-income countries, drowning remains a significant public health issue. The WHO's 2014 Global Drowning Report (GDR) indicated that high-income countries have made significant progress on reducing the number of drownings. Similarly, Langendorfer (2011) noted that the number of drowning fatalities in high-income countries has steadily declined over the past 30-50 years. However, when evaluating injury surveillance data, the US did not show a dramatic decrease in drowning fatalities or drowningrelated non-fatal injuries when comparing data from the year 2000 to the year 2010. Per the Centers for Disease Control and Prevention (CDC; 2013), the US experienced 3,482 drowning deaths $(1.24$ per 100,000$)$ in the year 2000, and a decade later in 2010 there were 3,782 drowning deaths (1.22 per 100,000). In 2000 there were 7,840 reported non-fatal drowning injuries 95\% CI $[3,655,12,025](2.80$ per 100,000$)$ and in 2010 there were 7,306 reported non-fatal drowning injuries 95\% CI [4,383, 10,229] (2.48 per 100,000) (CDC, 2013).

Certain population sub-groups, including minorities and individuals with disabilities, have been reported to have higher than average drowning rates (CDC, 2014). For example, children who are African American in the 5-19 age range drown in swimming pools at rates 5.5 times that of children who are Caucasian (CDC, 2014). In a study by Irwin, Irwin, Ryan, and Drayer (2009a, 2009b) that examined the risk factors associated with race, it was found that 
approximately fifty-eight percent (57.5\%) of African American and fifty-six percent (56.2\%) of Hispanic and Latino respondents self-reported having a high risk around water by not being comfortable in deep water and being unable to swim, as compared to only $30.9 \%$ of Caucasians respondents perceiving high risks. Additionally, Grosse (2014) explored aquatic safety issues related to individuals with autism spectrum disorders (ASD), who are at a much higher risk of drowning and other unintentional injury-related deaths. As drowning continues to be a major unintentional injury/fatality, education and research are looked upon as prevention methods to reduce drowning rates.

\section{Drowning Prevention Education}

In 2009, National Drowning Prevention Alliance (NDPA) released a position paper discussing layers of protection around water. The paper called for (a) active parent supervision when water is present, even if no water activities are taking place, and (b) the need for constant and responsible supervision among parents, caregivers, and other adults in addition to the presence of lifeguards. Adults being within arm's reach of infants and toddlers in or around water (touch supervision), use of water-watcher tags, and choosing proper floatation devices were all recommendations for parents. In addition, learning to swim has also been cited as an additional layer of protection for children and adults (NDPA, 2009).

Developing competent swimming skills has been the focus of several research studies aimed at further reducing an individual's drowning risk. Brenner et al. (2009) used a case-control study to determine the association between swimming lessons and drowning risk among children ages 1 to 19 years in the US. Results showed a statistically significant association between previous participation in formal swimming lessons and drowning risk for children ages 1-4. A reduction in drowning risk of $88 \%$ [CI 3\%, 99\%] was found for this age range, providing strong 
support for participation in swimming lesson for children ages 1-4. However, the authors pointed to limitations including a small sample size, possible bias, and wide confidence intervals (Brenner et al., 2009). Yang et al. (2007) completed a similar case-control study in China to determine risk factors for childhood drowning in rural regions of a developing country, and found that providing an educational program on drowning reduced childhood drowning by as much as 40\%; however, for similar reasons as Brenner et al. (2009), the results could contain potential bias. Though both the Brenner et al. (2009) and Yang et al. (2007) studies had inherent methodological limitations as case-control research, both suggested a potential reduction in drowning risk with a proper or formal educational program on drowning prevention/swimming. In addition to gaining competent swimming skills, parents and caregivers have been cited as a key layer of protection to prevent drowning (NDPA, 2009). Parents and caregivers are not only the first line of defense against drowning, they are also responsible for implementing protective barriers prevent drowning. Moran and Stanley (2006) conducted a study in New Zealand to gauge parents' reasoning for enrolling their child in swimming lessons and their understanding of the purpose of these lessons. Learning to swim was ranked as the highest reason on both pre- and post-lesson questionnaires (pre- 43.4\%, post- 41.9\%). While safety (pre$34.9 \%$, post- $25.7 \%$ ) ranked much lower on the post-lesson questionnaire, confidence in swimming (pre- $16.0 \%$, post- $23.8 \%$ ) ranked higher in the post-lesson questionnaire, indicating that parents saw value in increasing their child's confidence in the water after reviewing the resources provided (Moran \& Stanley, 2006).

Blitvich, Moran, Petrass, McElroy, and Stanley (2012) completed research in Australia to determine swim instructor beliefs surrounding the topics of swimming and water safety $(n=133)$. Eighty-four percent of the instructors felt that parental supervision was the most important 
element for safety around the water. The study provided insight into the parental belief that a child is "drown-proof" after swimming lessons, even when that is not the case (Blitvich et al., 2012). Morrongiello, Sandomierski, and Spence (2013) completed a longitudinal study ( $n=301)$ to determine how involvement in swimming lessons affects parent understanding of a child's drowning risk. Results showed that parents' perceptions of their child's swimming ability had significantly increased $(p<.001)$ after taking swim lessons. Additionally, it was found that parents perceived that a child's swimming ability was enough to keep their child safe around the water $(p<.001)$. The study also found that parents are poor judges of their child's actual swimming abilities and ability to keep themselves safe around the water, which is a problem since parents and caregivers are responsible for implementing protective barriers to keep children safe (Morrongiello et al., 2013).

In addition to the role of parents and instructors, educating children on proper water safety behavior is also an important step. Moran (2009a, 2009b) conducted studies among year 11 students $(n=2,202)$ from 41 high schools in New Zealand with the purpose of understanding how children learn about water safety. Results of the study indicated that there was a significant difference $(p<.001)$ regarding who influenced male and female students' knowledge of water safety. It was found that male students are 10 times as likely as female students to gain their beliefs towards water safety from their friends. This finding is problematic since males are more likely to partake in high-risk activities/behaviors and have poor knowledge of water safety (Moran, 2008a, 2008b). Females, however, were more likely to gain their beliefs towards water safety from their families and schools (Moran, 2009a, 2009b). Moran (2009a) also revealed that socio-economic status was not identified as a factor associated with how children learn about water safety. These findings help in understanding how children and young adults formulate their 
water safety knowledge and will help in identifying solutions to revise current water safety and drowning prevention education programming.

\section{Identifying Priority Research}

In the WHO's 2014 GDR, 10 action steps were described to help reduce drowning on a global scale. The last of these action steps related to future research, and highlighted the need to “address priority research questions with well-designed studies" (p. 48). Though research has been conducted surrounding the incidence of drowning, future research must identify and answer priority questions with the goal of better understanding drowning, enhancing drowning prevention education, and enhancing rescue/response abilities to help reduce drowning on a global scale. Unanswered questions remain in areas such as the correlation of swimming ability and drowning risk (Stallman, Junge, \& Blixt, 2008), best practices of presenting drowning prevention and water safety education (Moran \& Stanley, 2006), and racial/cultural relations to drowning risk (Irwin et al., 2009a).

The CDC has highlighted that data collection methods for injury surveillance contain potential flaws. A 2012 report from the CDC explained several barriers that limit the collection and analysis of surveillance data regarding injuries. Addressing gaps in data collection, improving access to data, and improving analysis, interpretation, and dissemination were addressed as goals for the future (CDC, 2012). Additionally, estimates of fatal to non-fatal drowning comparisons vary and have been reported as 2-4 times higher than fatal drowning rates by Suominen and Vahatalo (2012), and 1 death per 13 survivors of drowning by Layon and Modell (2009; as cited in Clemens, 2013). Many nationally affiliated organizations such as the Australian Water Safety Council (AWSC), the NDPA, and the American Red Cross (ARC) have all emphasized goals focused on a reduction in drowning rates. 
When an academic field experiences numerous challenges, such as drowning prevention education, it is reasonable for scholars to look to existing literature for suggestions and guidance on how to move forward with future research. For example, Pate et al. (2013) and Chen (2013) published papers outlining a list of the top 10 important research questions related to children's physical activity and children physical activity motivation respectively, both based on an extensive review of relevant literature. Reviews of literature and synthesis of important research questions are appropriate approaches in certain fields of study with substantial supporting literature. Yet, two flaws exist in this practice: (a) being able to bracket the researcher's own opinions and (b) little to no validation that these important research questions are truly top priorities in the field. Since drowning prevention education can be comparatively considered an under-researched area of scholarship, an extensive review of the literature would not likely yield strong research questions such as in Pate et al. (2013) and Chen's (2013) work, nor would this method result in assigning a priority level of importance to these questions. Thus, the use of research-based approach to analyze the opinions of the current experts in the field is needed.

\section{Statement of Significance}

While drowning injury and fatality rates in the US remain largely unchanged in recent years, existing research has not developed a supportive foundation to identify and promote priority outstanding research questions.

\section{Statement of Purpose}

The purpose of this research was to develop consensus among discipline experts on future research endeavors surrounding drowning prevention education initiatives in the US.

\section{Research Questions}

This study addresses the following research questions: 
RQ1. What do experts in drowning prevention education in the United States identify as research questions needing to be addressed in future research?

RQ2. What priority can be assigned to each research question on drowning prevention education in the United States?

Sub-RQ2A: What differences in priority exist between experts in practice and experts in scholarship?

RQ3. What themes are present across the identified priority research questions?

\section{Method}

This research employed a 3-round Delphi procedure to (1) survey experts to brainstorm research questions needing to be addressed in the US and (2) seek consensus on the rating of importance of each research question. Following consensus building, a qualitative cluster analysis was completed to highlight related themes among research questions. The Delphi method is a consensus building and forecasting technique that has been used across many different fields such as nursing research (de Mello Perieira \& Titonelli Alvim, 2015), construction management research (Sourani \& Sohail, 2015), health science research (Wong et al., 2014), and across many other areas of study. The Delphi method allows for (1) complete anonymity of the participants, (2) the opportunity for participants to change their views and opinions, (3) a more in-depth analysis of the results of the study, and (4) for follow-up and validation studies to be completed (Skulmoski, Hartman, \& Krahn, 2007).

\section{Participants}

Participants included an expert panel of researchers, educational decisions makers, and highly qualified practitioners in drowning prevention and water safety education. Replicating an existing or previously implemented inclusion criteria was not possible. Thus, US-based, experts 
were invited to participate based on meeting a minimum of 3 of the following criteria: (1) cited as a contributing author on a minimum of two research products; (2) published or presented a minimum of two peer reviewed/refereed articles or presentations; (3) developed or co-developed a drowning prevention or water safety education program or curriculum; (4) published a minimum of two issues or practitioner-based articles; (5) compiled a minimum of five years teaching drowning prevention or other aquatic education; (6) held employment in the field of drowning prevention/water safety education or other aquatic education for a minimum of five years; (7) worked with or directly for a national drowning prevention or water safety-related organization for at least three years; (8) completion of an instructor or trainer certification in water safety or drowning prevention from a recognized organization. Table 1 details the participant demographics for each round of surveying.

Expert participants were identified through several different processes including reviews of relevant literature, reviews of conference proceedings related to drowning prevention, and authorship in curricula, training materials, and educational content related to drowning prevention. While the sample sizes for expert panels in a Delphi study vary widely, this study invited 119 experts to participate. Participation by round included Round 1 ( $n=70)$, Round 2 $(n=42)$, and Round 3 ( $n=42)$. All participants completed the same surveys as one group; participants were divided into two different sub-groups for the purposes of a post-hoc analysis. Participants were placed into the experts in "scholarship" sub-group if 2 or more of their qualifications are from categories 1-4 in the inclusion criteria. Scholarship group participation by round included the following: Round 1 ( $n=43)$, Round 2 ( $n=26)$, and Round 3 ( $n=24)$. Participants were placed into the experts in "practice" sub-group if they meet the qualifications for participation, yet do not qualify for the "scholarship" group. Practice group participation by 
round included the following: Round $1(n=27)$, Round $2(n=16)$, and Round $3(n=18)$. All qualified participants were invited to participate in Round 3 regardless of if they participated in Round 2. Thirty-two ( $n=32)$ participants participated in all rounds of surveying: scholarship group ( $n=19)$, and practice group $(n=13)$. Twenty $(n=20)$ participants participated in either Round 2 or 3: scholarship group $(n=12)$, and practice group $(n=8$; see Table 1$)$.

\section{Procedures}

Data collection procedures used in this research were informed by the work of Blackwood, Albarren, and Latour (2011); Bulger and Housner (2007); Falzarano and Genevieve (2013); Katcher et al. (2006); and Plüddemann et al. (2010).

Round 1. After IRB approval was granted, the first round of surveying began. Participants $(n=119)$ were invited to Round 1 of surveying by an email which included a cover letter, consent information, and a link to the survey. An online survey tool, Qualtrics®, was used by participants to complete 2 web-based surveys during the multiple rounds of surveying. During Round 1, participants completed a brief questionnaire on their demographical information work experience and job title/responsibilities. Participants were then presented with an initial prompt which read as follows:

In the following text boxes, please submit up to 5 questions you feel need to be addressed through research in drowning prevention and water safety education, with the goal of reducing drowning deaths in the United States. You are encouraged to write these in question form, however, if you are unable to form a question, simply write the topic or issues you feel needs addressed through research.

This round of surveying was open to participants for three weeks. After two weeks, the participants were sent a follow-up email as a reminder. Only those who participated in Round 1 
were invited to participate in Rounds 2 and 3. Directly after all Round 1 surveys were completed, results were downloaded into an electronic database. A qualitative content analysis procedure was used to synthesize results into the survey for Rounds 2 and 3.

Rounds 2 and 3. Procedures for Rounds 2 and 3 of data collection adhered to the same administrative procedures described above. Based on the 249 responses submitted in Round 1, 101 research questions were synthesized using a qualitative content analysis to be included in the survey in to be rated in Rounds 2 and 3 using a 7-point Likert scale. The importance scale the utilized for this study was developed by Vagias (2006) and read as follows: (1) Not at all Important, (2) Low Importance, (3) Slightly Important, (4) Neutral, (5) Moderately Important, (6) Very Important, and (7) Extremely Important. Both surveys were pilot-tested for face validity, clarity, and functionality using a small sample not included in the study. Only limited wording changes to the directions were recommended by the pilot test group.

For the purposes of this study, the consensus level was defined as the mean of a survey item being rated at 5.00 (Moderately Important) or above. Additionally, any item with a mean score rated at 6.00 (Very Important) or above during Round 2 was considered to have met consensus as a priority research question and was not included in Round 3. To enhance consensus building among participants, a detailed report including the mean ratings of each question from Round 2 was disseminated to participants before Round 3. Panel members were instructed to review the results from Round 2 and reconsider their ratings for Round 3. Results were downloaded into an electronic database for analysis.

\section{Data Analysis}

After Round 1 was complete, a qualitative content analysis was conducted (Keeney, Hasson, \& McKenna, 2011, p. 65). The first step of this process involved reading the data 
multiple times to gain an understanding of all responses $(n=249)$ and establish a coding system. The second step was to identify similar questions and group them together using the established coding system. The researcher also identified responses that were not in question form and attempted to reformat these responses as appropriate. During this time the researcher attempted to bracket his own opinions and beliefs to limit bias. Two research assistants with extensive qualitative data analysis experience assisted in this process to assure that any bias was limited. Additionally, the researcher kept a log to keep track of data analysis and interpretations and documented where potential bias may occur. The result of this process was a complete list of research questions $(n=101)$ to be included in the survey for ratings in Rounds 2 and 3.

At the conclusion of Round 3, the mean rating of each research question was calculated and analyzed. In addition to mean score calculations, a Mann-Whitney $U$-test was also completed to analyze for differences in ratings between the two groups. The procedures for the post-hoc qualitative analysis of the results from the Delphi were informed by Ross, Metcalf, Bulger, and Housner (2014) and by the recommendations of Kennedy (2004). This process involved clustering related research questions together and structuring them based on their mean rating of importance. Given the lack of an existing template, structure, or theory surrounding this research area, a grounded theory approach (Glaser \& Strauss, 1967) was utilized. An inductive coding process (Saldana, 2013) was used to analyze the data for emerging related topics. After initial inductive codes were developed independently, researchers met and discussed their results. During this meeting, the researchers agreed on related topics appearing in the data and formed categories using a content analysis approach (Vaismoradi, Turunen, \& Bondas, 2013). Researchers met a minimum of a 90\% inter-coder reliability level (range $=95-100 \%$ ) before the titles and content of each developed category was firmly agreed upon (Miles, Huberman, \& 
Saldana, 2014). Once major categories were identified, researchers coded each research question independently and placed it under one of the overarching categories. Research questions relating to each categories' topic were organized numerically based on each question's mean rating of importance.

\section{Results}

Two-hundred forty-nine ( $n=249)$ responses were submitted by 70 participants during Round 1 of data collection. The qualitative content analysis conducted between Rounds 1 and 2 revealed 101 research questions related to drowning prevention and water safety education within the US. Of these 101 research questions, 84 questions met the consensus level $(\mu \geq 5)$ as being rated as moderately important after all rounds were completed and were included in the final analysis; 17 questions failed to meet the consensus level $(\mu<5)$ and were dropped from consideration. Nine of the 84 research questions meeting consensus were rated with an overall mean score of 6 or higher and were classified as priority research questions (see Figure $1 \&$ Table 2). A Mann-Whitney $U$-test was completed, and no significant differences in question ratings were found between the two sample sub-groups ( $p>.05)$. A qualitative cluster analysis on the 84 questions meeting consensus revealed six research topic areas: Educational Programming Effectiveness, Lifeguard Protocols and Victim Recognition, Aquatic Policy and Safety, Surveillance Data, Communication, and Socio-Cultural and Demographic Factors. Results, including overall mean ratings and ratings by group, are displayed in Tables 3-8 and discussed below.

\section{Education and Programming Effectiveness}

Twenty-four research questions relating to the design, delivery, and evaluation of swimming and water safety education were clustered in this category. This category represented 
$28.6 \%$ of the total research questions meeting consensus and had an overall mean score of 5.37 out of $7.00\left(\mu_{\text {scholarship }}=5.42 ; \mu_{\text {practice }}=5.33\right)$. Two research questions were rated as priority while the remaining 22 were rated as moderately important. The priority research questions were item \#3; "What impact does parent education of water safety have on child drowning prevention?" and item \#9; "What, if any, effect does including water safety in a K-12 school's curriculum have on the reduction of drowning risk?" When comparing the differences between groups, five research questions were rated above the consensus level by the scholarship group and not by the practice group, and one research question rated above the consensus level by the practice group and not the scholarship group. The most substantial variability between groups ratings existed in the following questions; item \#63, item \#68, item \#9, and item \#71. Results from this category are represented in Table 3.

\section{Lifeguard Protocols and Victim Recognition}

Nine research questions relating to the training, practice, and effectiveness of lifeguards were included in the category. This category represented $10.7 \%$ of the total research questions meeting consensus and had a total mean score of 5.71 out of $7.00\left(\mu_{\text {scholarship }}=5.66 ; \mu_{\text {practice }}=5.78\right)$. Two research questions were rated as priority research questions while the remaining seven were rated as moderately important. The priority research questions were item \#5; "Are lifeguards and parents effective at recognizing a drowning victim and what can be done to increase victim recognition?" and item \#8; "Is there a significant difference between drowning rates when lifeguards are present?" When comparing the differences between groups, there was only one research question that was rated below the consensus level by the scholarship group and not by the practice group. The practice group rated all questions in this category above the consensus 
level. The most substantial variability between groups ratings existed in the following questions; item \#12, item \#78, and item \#5. Results from this category are represented in Table 4.

\section{Aquatic Policy and Safety}

Thirteen research questions involving policy, regulation, and guidance related to aquatic safety were included in this category. This category represented $15.5 \%$ of the total research questions meeting consensus and had a total mean score of 5.49 out of $7.00\left(\mu_{\text {scholarship }}=5.42\right.$; $\left.\mu_{\text {practice }}=5.58\right)$. Three research questions were rated as priority research questions while the remaining ten were rated as moderately important. The priority research questions were item \#1; "What strategies are most effective in increasing parental supervision of children around bodies of water?" item \#4; "What can be done to increase parental supervision when lifeguards are present?" and item \#6; "What do parents/caregivers believe their role is in an aquatic environment?" When comparing the differences between groups, there was one research question that was rated above the consensus level by the scholarship group and not by the practice group, and one research question rated above the consensus level by the practice group and not the scholarship group. The most substantial variability between groups ratings existed in the following questions; item \#69, item \#52, item \#3, item \#51, item \#82, and item \#36. Results from this category are represented in Table 5.

\section{Surveillance Data}

Fifteen research questions relating to continuous, systematic collection, analysis, and interpretation of drowning and aquatic injury data were included in this category. This category represented $17.9 \%$ of the total research questions meeting consensus and had a total mean score of 5.34 out of $7.00\left(\mu_{\text {scholarship }}=5.42 ; \mu_{\text {practice }}=5.33\right)$. No priority research questions were identified in this category. When comparing the differences between groups, there were no research 
questions that the scholarship group rated below the consensus level, but there were four research questions that the practice group rated below the consensus level. The most substantial variability between groups ratings existed in the following questions; item \#83, item \#22, item $\# 73$, and item \#24. Results from this category are represented in Table 6.

\section{Communication and Public Awareness}

Nine research questions relating to unifying a public message for Americans related to drowning prevention were included in this category. This category represented $10.7 \%$ of the total research questions meeting consensus and had a total mean score of 5.37 out of 7.00 $\left(\mu_{\text {scholarship }}=5.41 ; \mu_{\text {practice }}=5.31\right)$. One research question was rated as priority while the remaining eight research questions were rated as moderately important. The priority research question was item \#2; "What can be done to increase public recognition of drowning as a public health issue?" When comparing the differences between groups, there was one research question that was rated above the consensus level by the scholarship group and not by the practice group. Only one question in this category, item \#2, had a substantial variability between group ratings. The scholarship group rated all questions in this category above the consensus level. Results from this category are represented in Table 7.

\section{Socio-Cultural and Demographic Factors}

Fourteen research questions relating to the examination of individuals/group characteristics including race, gender, culture, socio-economic status, age, and disability were included in this category. This category represented $16.7 \%$ of the total research questions meeting consensus and had a total mean score of 5.31 out of $7.00\left(\mu_{\text {scholarship }}=5.31 ; \mu_{\text {practice }}=5.32\right)$. One research question was rated as priority while the remaining thirteen research questions were rated as moderately important. The priority research question was item \#7; "What role do 
different levels of water competence (a.k.a., swimming skill level) play in preventing fatal and non-fatal drownings?" When comparing the differences between groups, there were two research questions that were rated above the consensus level by the scholarship group and not the practice group, and there were two research questions that were rated above the consensus level by the practice group and not the scholarship group. Only one question in this category, item \#70, had a substantial variability between group ratings. Results from this category are represented in Table 8 .

\section{Discussion}

Six categories of related research questions related to the field of drowning education prevention emerged in this study: (1) Education and Programming Effectiveness, (2) Lifeguard Protocols and Victim Recognition, (3) Aquatic Policy and Safety, (4) Surveillance Data, (5) Communication and Public Awareness, and (6) Socio-Cultural and Demographic Factors. These categories were formed from the 84 research questions meeting the consensus level from the expert panel's ratings. Nine of the 84 questions were rated as very important and were thus classified as priority research questions needing to be addressed in drowning prevention education research in the US.

The foundation of the current study is rooted in the WHO's (2014) GDR's 10 action steps to prevent drowning, where the last action step addressed future research needs. The description of the action step listed under the "Future Research," category was to "address priority research questions with well-designed studies" (pg. 39). The Future Research action step listed five key areas identified as future research needs including; (1) improving data, (2) improving understanding of swim skills training as a public health approach, (3) improving understanding of the contextual features that impact drowning program effectiveness, (4) improved 
understanding of effectiveness for a number of potential interventions, and (5) demonstrating scalability and sustainability for effective drowning prevention measures (WHO, 2014). While the GDR is written from a global perspective, the current study is a first step towards identifying important research questions in the US.

Several similarities can be identified between the six categories of research questions that emerged in this study and the five key areas related to future research reflected in the GDR. Even though the GDR is written from a global perspective and many of the recommendations apply to low- and middle-income countries, connections to the current study's results are still evident. Key area one discussed improving drowning data, which was addressed by expert panel members in the Surveillance Data category. Even though no research questions relating to surveillance data were rated as priority research questions, 15 research questions met the consensus level as moderately important research questions. The second key area in the GDR report discussed improving swim skill training as a public health approach, which expert participants addressed in the Education and Programming Effectiveness category of the current study. Research questions meeting consensus discussed the importance in gaining an increased understanding of how best to approach swim skill training for all ages, and in different environments. Key areas three and four discussed improving the understanding of the contextual features of drowning programs and the effectiveness of interventions for drowning. Future research was identified throughout all six categories in the current study relating to key areas three and four. Topics in key areas three and four of the GDR discussed included increasing supervision of children, legislative efforts, alcohol and drugs usage around water, CPR and response training, and how best to teach drowning prevention and water safety education. Similarly, key area five of the GDR discussed the scalability and sustainability for effective 
drowning prevention measures. This last key area strongly relates to the Surveillance Data and Aquatic Policy and Safety categories, where important research questions related to increasing knowledge of the cost of drowning, identifying high risk locations, and prioritizing drowning preventions strategies.

The current study not only identified key research areas needing to be addressed, but further (1) ascertained what specific research questions exist and (2) assigned each one with a rating of importance. Immediacy is warranted to answer the nine priority research questions, as future research will improve and strengthen drowning prevention education in the US. Each of the priority research questions will be discussed (Items \#1 - \#9; see Table 2), followed by a summary of all research questions meeting consensus. Many of the identified priority research questions have limited evidence in the existing body of knowledge surrounding water safety and drowning prevention, which further supports their ratings.

Three priority research questions (Items \#1, \#4, \& \#6) related to increasing parent supervision around water. Item \#1 was the highest rated question in the Aquatic Policy and Safety category, as well as the highest rated question of the entire study by both experts in scholarship and experts in practice. All three research questions centered around increasing parental supervision around water (Items \#1 \& \#4) and what parents perceive their role is an aquatic environment (Item \#6). Ramos et al. (2015) highlighted constant attention to the children being supervised in water as a key component of the drowning intervention process. Blitvich et al. (2012) discussed that many parents believe that their child is drown-proof after swimming lessons, which is not the case and may lead to decreased parental supervision. This is supported by Morrongiello et al. (2013), who found some parents believe that swimming skills alone are enough to prevent drowning. In addition, Morrongiello et al. found that in some cases parents are 
poor judges of their child's swimming ability and poor judges of their child's ability to stay safe around water.

Gaining an understanding of the perception of parents/caregivers regarding their role in an aquatic environment, and formulating how to increase supervision of parents/caregivers, are both important steps to increasing safety around water. It seems most appropriate that future research follow a mixed method design by integrating exploratory, survey, and case study designs. Based on the research questions (Items \#1, \#3, \& \#6), future research should focus on what parents perceive their role to be while their children are in or around water. A future research study might be structured around (1) surveying parents to determine what parents believe their role is in an aquatic environment and on their supervision practice, (2) interviewing parents to determine their behaviors when supervising their children around water, and (3) providing different types of parent education to determine the most effective cognitive and affective behavior change approach. Future research must focus on the parent perspective with the goal of creating more effective parental educational programming.

Similar to the parent's role in an aquatic environment, the two priority research questions related to educational and programming endeavors (Items \#3 \& \#9). These questions centered around determining effective approaches towards swimming and water safety education curriculum development, learner retention of information, and behavior change. Item \#3 related to parent education regarding water safety and drowning prevention. This is an interesting finding considering that limited research exists surrounding the relationship between parent education and increased safety for children around water. National organizations such as the NDPA (2009) have called for constant parental/caregiver supervision, the use of water-watcher tags, proper rescue training, and proper flotation devices; yet limited evidence exists suggesting 
parental education is effective. Further, researchers such as Morrongiello at al. (2013) have shown that parents can be poor judges of their child's swimming abilities and have misconceptions that swimming skills alone are enough to keep children safe around water. Future research studies surrounding the broader topic of parent water safety knowledge and its effect on children may look towards case study research. While not likely generalizable to the entire population, case study designs would allow for a better initial understanding of how parent knowledge may affect a child's risk of drowning or the child's own water safety practices. To determine this, a longitudinal design seems most appropriate in gaining an initial understanding of how water safety education effects parents and their children. Based on these results, followup research efforts can then be based around gaining an understanding of the population at large and how best to introduce water safety information to parents.

Also, related to education was Item \#9, which discussed effectiveness of drowning prevention and water safety education in K-12 curricula. While limited research exists surrounding actual effectiveness of drowning prevention education in K-12 schools, recent research has evaluated instructor beliefs. Beale and Lynn (2011) found agreement among K-12 physical education instructors that water safety and drowning prevention is an important part of an aquatic physical activity curriculum and research. Blitvich et al. (2012) found that pre-school aquatic instructors felt safety was the most important element of toddler swimming lessons. While research has shown that swimming instructors perceive safety is important, limited research is available to show that a $\mathrm{K}-12$ water safety curriculum is effective at reducing drowning risk. Future research addressing a relationship between teaching water safety in K-12 and a reduction in drowning risk will likely require mixed-methods approach. This can be accomplished by integrating qualitative or exploratory research due to limited supporting 
research, following a longitudinal design to track if there is any lasting effect between what is learned and a reduction in risk, and a causal design to strengthen the research body to show that learning water safety in K-12 would lead to a reduction in drowning risk.

While parent roles and water safety education are important components towards safer water, the topics of training, development, and practices of lifeguards were also rated as a priority by participants. The category related to lifeguard training, practices, and effectiveness was not the largest category by the number of important research questions; however, the questions in this category received the highest collective mean ratings among both experts in scholarship and experts in practice. Item \#5 was the highest rated priority question relating to Lifeguard Protocols and Victim Recognition. Item \#5 related to parent and lifeguard abilities to recognize a drowning victim. While this question was not rated as highly by the experts in practice, both groups saw the topic as an important focal area in both lifeguard and parent supervision around water. Limited research has been conducted on victim recognition since Pia's (1974) original research on the "IDR". Further, Pia's (1982) R.I.D. Factor model as to why victims drown when a lifeguard is on-duty has seen little to no revisions since first published. Because of the limited supporting foundation, future exploratory-based research is recommended to better identify what drowning victim's behavior and characteristics are and how that knowledge can be applied the recognition of drowning by parents and lifeguards.

Also related to victim recognition was Item $\# 8$, which discussed the differences in drowning rates when parents versus lifeguards are responsible for surveillance. Lifeguard training programs address surveillance; however, current literature suggests that lifeguard training does not effectively train lifeguards to recognize drowning victims. Pelletier and Gilchrist (2011) reviewed 106 cases and found that lifeguards only successfully recognized a 
drowning victim $22 \%$ of the time. In the remaining $78 \%$ of cases, a bystander recognized the drowning and alerted a lifeguard (Pelletier \& Gilchrist, 2011). Additional research by LanganLeitzel and Moore (2010) revealed initial findings that lifeguard recognition of events that could lead to a drowning was no different than an untrained bystander. Future research is not only needed to address lifeguard victim recognition and scanning techniques, but also to determine what outside variables affect a lifeguard while attempting to perform surveillance duties. To best address this problem, a focus on the environmental factors effecting lifeguards and how they are best overcome is needed.

In regards to public messaging, Item \#2 discussed increasing public recognition of drowning as a public health issue. This question also had a wide variation in mean ratings between groups. This is a broad research question and would likely need more narrow focus in order to guide a research study. However, there was consensus among the expert panel that drowning does not receive the public recognition needed. This is an important finding since there are several national campaigns that focus on drowning prevention and water safety (i.e. Pool Safely Campaign and Wear It Campaign). While there is limited existing research on drowning's current recognition level with the public-at-large, other questions in the Aquatic Policy and Safety category also encompassed the effectiveness of public campaigns by organizations such as the Consumer Product Safety Commission (CPSC), the CDC, and various state and local health departments in the US. Research should be conducted to analyze the effectiveness of national campaigns and messaging to address why drowning does not receive the public recognition study participants feel it deserves.

As the final priority research question, Item \#7 discussed differing levels of water competency and their relation to preventing drowning. Even though Brenner et al. (2009) and 
Yang et al. (2007) both completed case control research to identify if learning how to swim had any reduction on drowning risk, neither study yielded strong statistically significant results. As case control research, Brenner et al. and Yang et al. did provide a first step in the process of identifying if swimming skills or competencies have a relation to drowning risk. However, even with existing research, expert panelists still rated this research as having priority status. It is likely that expert participants felt that further research beyond Brenner et al. and Yang et al.'s findings must be completed to provide stronger support for learning to swim in order to reduce drowning risk. It is recommended that future research replicate existing case control research protocols to gain a deeper understanding of water competencies and their relation to drowning risk.

The 75 moderately important research questions meeting consensus should also be considered in future research. While not every category or question was rated as highly as the ones discussed in detail above, there are two additional findings worth noting. The category involving drowning and aquatic injury surveillance data was surprisingly one of the lowest rated among all categories and had no research questions rated as very important. With the wellknown issues, barriers, and limitations surrounding fatal and non-fatal injuries in the US (CDC, 2012) it is surprising that questions related to this topic were not rated highly by participants. While the known limitations on collecting surveillance data related to drowning were included on the list of important research questions, the highest rated question in the Surveillance Data category reflected gaining more information on what type of accidents are taking place and where they are occurring rather than addressing systematic improvements needed to address overall data collection barriers. It was also interesting that research surrounding the economic impact of both fatal and non-fatal drowning was not rated as more important by participants 
given annual estimates that put the cost at over $\$ 6$ billion per year. (CDC, 2013). Additionally, as noted by Clemens (2013), wide variations in fatal to non-fatal drowning ratios exist, so it is noteworthy that this was not thoroughly addressed by study participants.

It was surprising that the Socio-Cultural and Demographic Factors category had the lowest overall mean rating considering that research on minority populations and disability is one of the topic areas with the most depth in drowning prevention research, with recent work published by the CDC (2014); Fralick, Gallinger, and Hwang (2013); Golob, Giles and Rich (2013); Irwin et al. (2009a, 2009b); the Lifesaving Society of Canada (2010); and Martin and Witman (2010). It is possible that the higher levels of focus this specific topic area has received over the past decade may have resulted in an oversaturation in the literature, and participants did not see a need for much further study in this area. This category also experienced the least variability between group ratings, which supports the notion that both experts in scholarship and experts in practice agree that this specific research topic area has received considerable attention. While there were no statistically significant differences between sub-group ratings of each question based on the Mann-Whitney $U$-test, it was interesting to note some obvious variability between sub-group ratings in the Lifeguard Protocols and Victim Recognition, Aquatic Policy and Safety, and Surveillance Data categories (see Figures $2 \& 3$ ). Little to no variability was observed in the Education and Programming Effectiveness, Communication and Public Awareness, and Socio-Cultural and Demographic Factors categories. Yet, experts in practice rated both the Lifeguard Protocols and Victim Recognition and Aquatic Policy and Safety categories higher than experts in practice. The largest variability among group ratings occurred in the Surveillance Data category, which was rated as the overall lowest category by the experts in practice but rated much higher by experts in scholarship. This was possibly due to a 
reliance or higher familiarity by the experts in scholarship on drowning injury and fatality data in contrast to experts in practice, who likely do not rely as heavily on this type of data.

\section{Limitations}

While the current study provides insight into important research questions surrounding drowning prevention and water safety in the US, it does have inherent limitations and should be considered in context. This research was grounded in a thorough review of the literature body; however, the research questions rated in this study were developed only by the research participants and no questions were added or omitted by the researcher based on the review of literature. Developed questions that were rated may have already been addressed, in whole or in part, in past research studies. Additionally, the research participants were screened using specific and targeted inclusion criteria that was developed by the researcher. This could have limited participation by excluding an expert, or allowed individuals who would have not otherwise been considered as experts to participate in this research. This risk is minimal given the small number of experts available for this research area and that it was limited to only the US. Grouping participants together into scholarship and practice groups for a post-hoc analysis of the results may have also proven problematic given the researcher-developed inclusion criteria. There is a potential that participants might have been grouped incorrectly if they did not complete the demographics portion of the study accurately. Additionally, there is potential that higher level statistical analyses could have been conducted with a larger pool of participants.

The results of this study may not be generalizable outside of the US due to the inclusion criteria of participants. It may be worthwhile to replicate this same methodological approach in other countries based categorically on income, or collectively as an international approach to drowning prevention and water safety. Lastly, given the large amount of research questions 
developed after the brainstorming round of data collection, the resulting survey was long and did take considerable time to complete. This may have limited participation and potentially skewed results, or may have led to an increased mortality rate. This limitation was potentially minimized by the Delphi methods' use of multiple rounds of surveying.

\section{Conclusion}

The results of this study provide guidance for future research endeavors in the field of drowning prevention and water safety education in the US. Nine very important research questions, along with an additional 75 moderately important research questions, were developed and rated by experts in both scholarship and practice from within the US. The results of the qualitative cluster analysis provide insight into 6 distinct research categories that exist within drowning prevention education research. Further, the group mean ratings of each question show dissension and agreement on certain important research areas. Dissension between groups may point to areas in which experts in scholarship and experts in practice have differing understandings on the existing literature body and/or have differing professional experiences which may have influenced their ratings. It may prove worthwhile to further investigate these particular research questions to determine why these two groups viewed them differently.

While the WHO's GDR made recommendations on how to reduce drowning from a global perspective, the $10^{\text {th }}$ action step of addressing priority research questions with welldesigned studies is of limited use unless priority research questions have been identified. Within drowning prevention and water safety, this is inherently difficult due to; (1) a limited body of existing and relevant literature and; (2) the different drowning risks, resources, and supporting infrastructure available in each different country. Therefore, this study provides a useful and relevant resource for future research studies in the US relating to drowning prevention. The 
WHO’s GDR (2014) brings up the need for a “...mechanism that facilitates sharing of key findings and ideas among researchers, and prioritization of research studies will do much to ensure that resources are used effectively," (pg. 39). This current study serves as an essential first step in addressing the WHO's GDR's recommendations by identifying nine priority research questions that should be of the utmost importance to answer to further advance of the field of drowning prevention education. 


\section{References}

Beale, A., \& Lynn, S. (2011). Swimming in new waters: Profiling K-12 aquatic physical activity in Florida as a viable lifesaving force in physical education. International Journal of Aquatic Research and Education, 5(4), 402-420.

Blackwood, B., Albarran, J. W., \& Latour, J. M. (2011). Research priorities of adult intensive care nurses in 20 European countries: a Delphi study. Journal of Advanced Nursing, 67(3), 550-562. doi:10.1111/j.1365-2648.2010.05512.x

Blitivich, J. D., Moran, K., Petrass, L. A., McElroy, G. K., \& Stanley, T. (2012). Swim instructor beliefs about toddler and preschool swimming and water safety education. International Journal of Aquatic Research and Education, 6(2), 110-121.

Brenner, R. A., Taneja, G. S., Haynie, D. L., Trumble, A. C., Qian, C., Kliner, R. M., \& Klebanoff, M. A. (2009). Association between swimming lessons and drowning in childhood. Archives of Pediatric \& Adolescent Medicine, 163(3), 203-210. doi: 10.1001/archpediatrics.2008.563.

Bulger, S. M. \& Housner, L. D. (2007). Modified Delphi investigation of exercise science in physical education teacher education. Journal of Teaching in Physical Education, 26, 5780. doi: http://dx.doi.org/10.1123/jtpe.26.1.57

Centers for Disease Control and Prevention. (2012). National Action Plan for child injury prevention. Retrieved from http://www.cdc.gov/safechild/pdf/National_Action_Plan_for_Child_Injury_Prevention.p df

Centers for Disease Control and Prevention. Web-based Injury Statistics Query and Reporting System (WISQARS) [Online]. (2013). National Center for Injury Prevention and Control, 
Centers for Disease Control and Prevention (producer). Available from: URL: www.cdc.gov/ncipc/wisqars. [2015/3/30].

Centers for Disease Control and Prevention. (2014). Unintentional drowning: Get the facts.

Retrieved from: http://www.cdc.gov/HomeandRecreationalSafety/WaterSafety/waterinjuries-factsheet.html

Chen, A. (2013). Top 10 research questions related to children physical activity motivation. Research Quarterly for Sport and Exercise, 84(4), 441-447. doi:

$10.1080 / 02701367.2013 .844030$

Clemens, T. (2013). Proceedings from the World Conference on Drowning: Non-fatal drowning: A review of epidemiology, pathophysiology, treatment and prevention. Potsdam, Germany.

de Mello Pereira, R. D., \& Titonelli Alvim, N. A. (2015). Delphi technique in dialogue with nurses on acupuncture as a proposed nursing intervention. Anna Nery School Journal Of Nursing / Escola Anna Nery Revista De Enfermagem, 19(1), 174-180. doi:10.5935/14148145.20150024

Falzarano, M., \& Genevieve, P. Z., (2013). Seeking consensus through the use of the Delphi technique in health science research. Journal of Allied Health, 42(2), 99-105.

Fralick, M., Gallinger, Z. R., \& Hwang, S. W., (2013). Differences in drowning rates between rural and non-rural residents of Ontario, Canada. International Journal of Aquatic Research and Education, 7(4), 332-343.

Glaser, B.G. \& Strauss, A.L. (1967). The discovery of grounded theory: Stratagies for qualitative research. Chicago: Aldine Pub. Co. 
Golob, M. I., Giles, A. R., \& Rich, K. M. (2013). Enhancing the relevance and effectiveness of water safety education for ethnic and racial minorities. International Journal of Aquatic Research and Education, 7(1), 39-55.

Grosse, S. J. (2014). Aquatic safety for individuals with autism spectrum disorders. International Journal of Aquatic Research and Education, 8, 295-301. doi: 10.1123/ijare.2014-0043

H. Res. 1721, 110th Cong., 154 Cong. Rec. H11346 (2007) (enacted).

Irwin, C. C., Irwin, R. L., Ryan, T. D., \& Drayer, J. (2009a). The mythology of swimming: Are myths impacting minority youth participation? International Journal of Aquatic Research and Education, 3(1), 10-23.

Irwin, C. C., Irwin, R. L., Ryan, T. D., \& Drayer, J. (2009b). Urban minority youth swimming (in)ability in the United States and associated demographic characteristics: Towards and drowning prevention plan. Injury Prevention, 15(4), 234-239.

Katcher, M. L., Meister, A. N., Sorkness, C. A., Staresinic, A. G., Pierce, S. E., Goodman, B. M., \& ... Schirmer, J. A. (2006). Use of the modified Delphi technique to identify and rate home injury hazard risks and prevention methods for young children. Injury Prevention, 12(3), 189-194. doi:10.1136/ip.2005.010504

Keeney, S., Hasson, F., \& McKenna, H. (2011). The Delphi technique in nursing and health research. West Sussex, U.K.: Blackwell.

Kennedy, H. (2004). Enhancing Delphi research: methods and results. Journal Of Advanced Nursing, 45(5), 504-511. doi:10.1046/j.1365-2648.2003.02933.x

Langan-Leitzel, L. K., \& Moore, C. (2010). Do lifeguards monitor the events they should? International Journal of Aquatic Research and Education. 4(4), 241-256. 
Langendorfer, S. J. (2011). Considering drowning, drowning prevention, and learn to swim, International Journal of Aquatic Research and Education, 5, 236-243.

Lifesaving Society of Canada. (2010). Study reveals new Canadians at higher risk for drowning [Press release]. Retrieved from http://www.lifesaving.ca/index.php/study-reveals-newcanadians-higher-risk-drowning/

Martin, N. T., \& Witman, D., (2010). Factors affection minority drowning. International Journal of Aquatic Research and Education, 4(1), 9-18.

Miles, M. B., Huberman, A. M., \& Saldana, J. (2014). Qualitative data analysis. (3rd ed., p. 277). Thousand Oaks, CA: SAGE.

Moran, K. (2008a). Will they sink or swim? New Zealand youth water safety knowledge and skills. International Journal of Aquatic Research and Education, 2(2), 114-127.

Moran, K. (2008b). Youth aquatic recreation: The pleasures and pitfalls of an aquatic lifestyle in New Zealand. In N.P. Beaulieu (Ed.), Physical activity and children: New research (pp. 35-63). Hauppauge, NY: Nova Science Publishers.

Moran, K. (2009a). Parent/caregiver perception and practice of child water safety at the beach. International Journal of Injury Control and Safety Promotion, 16(4), 215-221. doi: $10.1080 / 17457300903307045$

Moran, K. (2009b). Parents, pals, or pedagogues? How youth learn about water safety. International Journal of Aquatic Research and Education, 3(2), 121-134.

Moran, K., \& Stanley T. (2006). Toddler drowning prevention: Teaching parents about water safety in conjunction with their child's in-water lessons. International Journal of Injury Control and Safety Promotion, 13(4), 254-256. 
Morrongiello, B.A, Sandomierski, M., \& Spence, J. R. (2013). Changes over swim lessons in parents' perceptions of children's supervision needs in drowning risk situations: "His swimming has improved so now he can keep himself safe.” Health Psychology 32(9), 18. doi: $10.1037 / \mathrm{a} 0033881$

National Drowning Prevention Alliance, Education Committee. (2009). Layers of protection around aquatic environments to prevent child drowning. Retrieved from http://www.floridahealth.gov/programs-and-services/prevention/drowningprevention/_documents/ndpa-position-paper.pdf

National Safe Boating Council (2014). Wear It! Campaign Awareness Survey. Retrieved from http://www.safeboatingcampaign.com/Wear-ItResearch-2014_9-5-2014-FINAL.pdf

Pate, R. R., O’Neill, J. R., Brown, W. H., McIver, K. L., Howie, E. K., \& Dowda, M. (2013). Top 10 research questions related to physical activity in preschool children. Research Quarterly for Sport and Exercise, 84(4), 448-455. doi: 10.1080/02701367.2013.844038

Pelletier, A.R., \& Gilchirst, J. (2011). Fatalities in swimming pools with lifeguards: USA, 20002008. Injury Prevention, 17(4), 250-254.

Pia, F. (1974). Observations on the drowning of non-swimmers. The Journal of Physical Education, 71(6), 164-167.

Pia, F. (1984). The RID factor as a cause of drowning. Parks and Recreation.

Plüddemann, A., Heneghan, C., Thompson, M., Roberts, N., Summerton, N., Linden-Phillips, L., ... Price, C.P. (2010). Prioritisation criteria for the selection of new diagnostic technologies for evaluation. BCM Health Services Research, (5). doi: 10.1186/14726963-10-109 
Ramos, W., Beale, A., Chamber, P., Dalke, S., Fielding, R., Kublick, L, ... Wernicki, P. (2015). Primary and secondary drowning interventions: The American Red Cross circle of drowning prevention and chain of drowning survival, International Journal of Aquatic Research and Education, 9, 89-101. doi: 10.1123/ijare.2014-0045

Ross, S., Metcalf, A., Bulger, S. B., \& Housner L. D. (2014). Modified Delphi investigation of motor development and learning in physical education teacher education. Research Quarterly in Exercise and Sport, 85(3), 316-329. doi: 10.1080/02701367.2014.930087

Saldana, J. (2013). The coding manual for qualitative researchers (2nd ed.). Los Angeles [i.e. Thousand Oaks, Calif: SAGE Publications.

Skulmoski, G. J., Hartman, F. T., \& Krahn, J. (2007). The Delphi method for graduate research. Journal of Information Technology Education, 6, 1-21.

Sourani, A., \& Sohail, M. (2015). The Delphi method: review and use in construction management research. International Journal of Construction Education \& Research, 11(1), 54-76. doi:10.1080/15578771.2014.917132

Stallman, R. K., Junge, M., \& Blixt, T., (2008). The teaching of swimming based on a model derived from the cause of drowning. International Journal of Aquatic Research and Education, 2(4), 372-382.

Vagias, W.M. (2006). Likert-type scale response anchors. Clemson International Institute for Tourism \& Research Development, Department of Parks, Recreation and Tourism Management. Clemson University.

Vaismoradi, M., Turunen, H., \& Bondas, T. (2013). Content analysis and thematic analysis: Implications for conducting a qualitative descriptive study. Nursing and Health Sciences, 15(3), 398-504. doi: 10.1111/nhs.12048 
Water Safety USA. (2016). Retrieved February 01, 2017, from http://www.watersafetyusa.org/

Wong, S. T., Browne, A. J., Varcoe, C., Lavoie, J., Fridkin, A., Smye, V., \& ... Tu, D. (2014). Development of health equity indicators in primary health care organizations using a modified Delphi. Plos ONE, 9(12), 1-15. doi:10.1371/journal.pone.0114563

World Congress on Drowning. (2002). Violence and injury prevention: Drowning. Retrieved from http://www.who.int/violence_injury_prevention/other_injury/drowning/en/

World Health Organization. (2014). Global Drowning Report. Retrieved from http://apps.who.int/iris/bitstream/10665/143893/1/9789241564786_eng.pdf?ua=1\&ua=1

Yang, L., Nong, Q.M., Li, C., Feng, Q.M., Lo, \& S.K. (2007). Risk factors for childhood drowning in rural regions of a developing country; A case-control study. Injury Prevention, 13(3), 178-182. doi: 10.1136/ip.2006.013409 


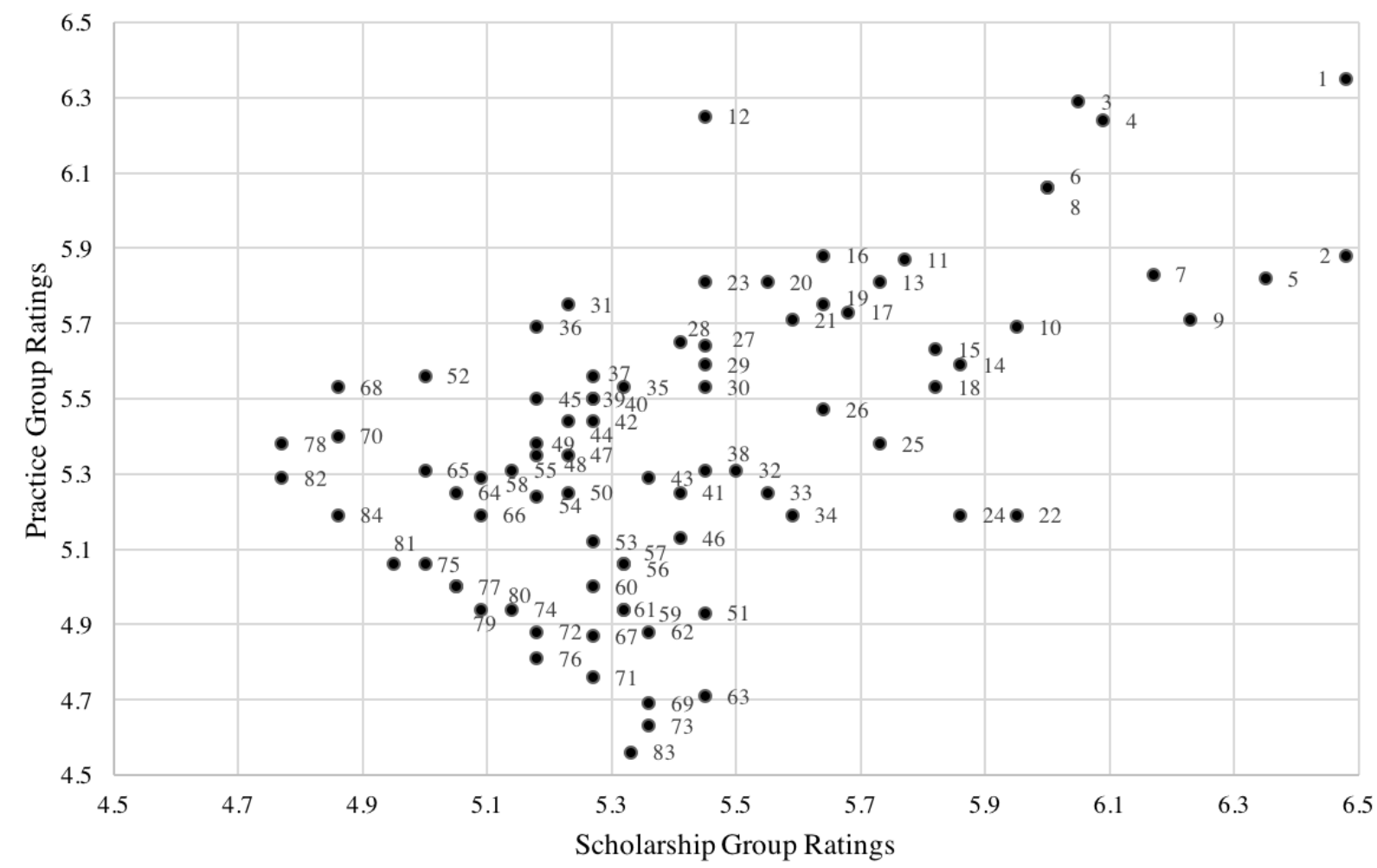

Figure 1. Mean ratings by sub-groups. This figure illustrates the mean rating of each item between sample sub-groups. 


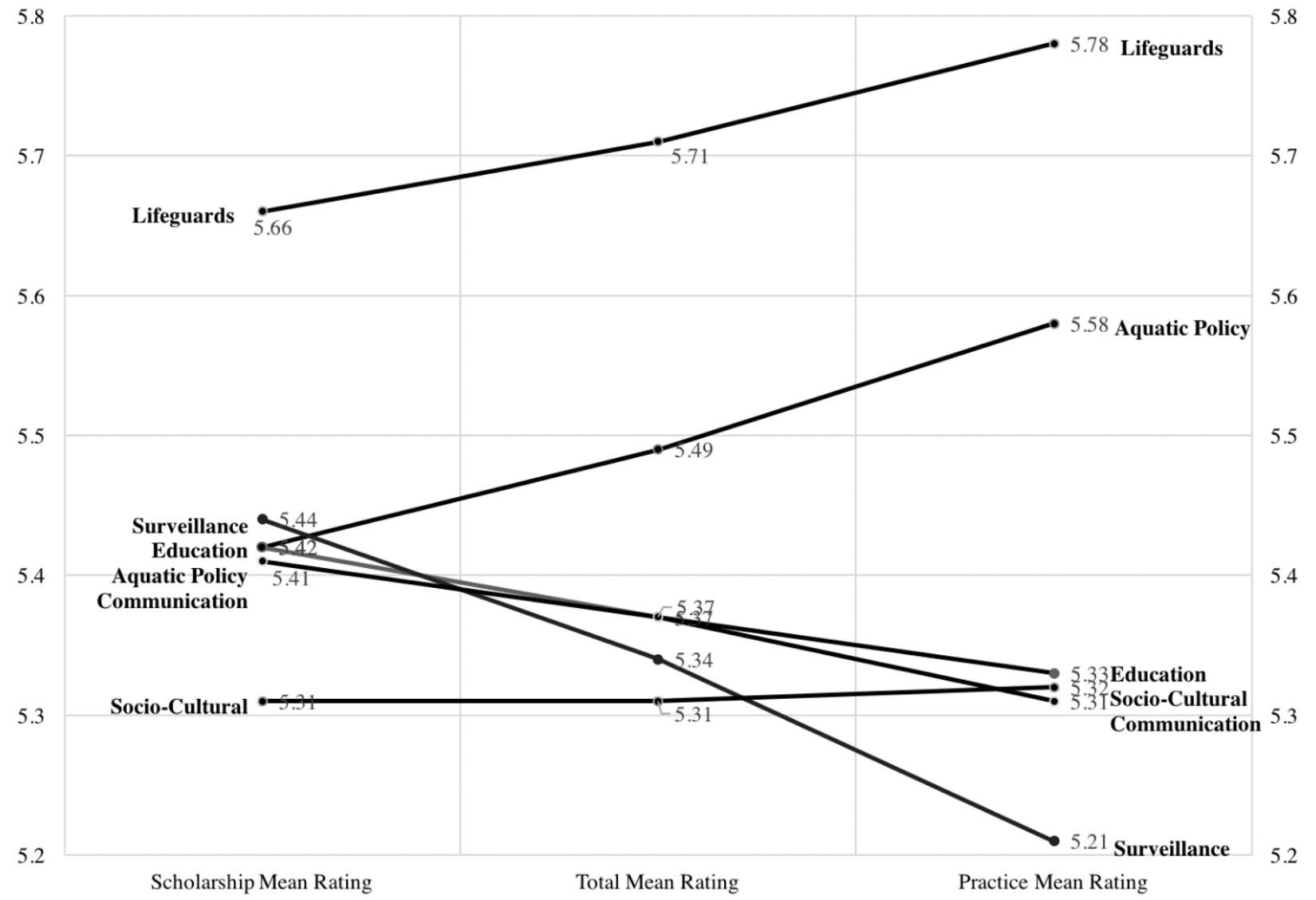

Figure 2. Group mean ratings by category. This figure illustrates the variability in ratings for each category between sample sub-groups (Education= Education and Programming Effectiveness; Lifeguards = Lifeguard Protocols and Victim Recognition; Aquatic Policy = Aquatic Policy and Safety; Surveillance $=$ Surveillance Data; Communication $=$ Communication and Public Awareness; Socio-Cultural = Socio-Cultural and Demographic Factors). 


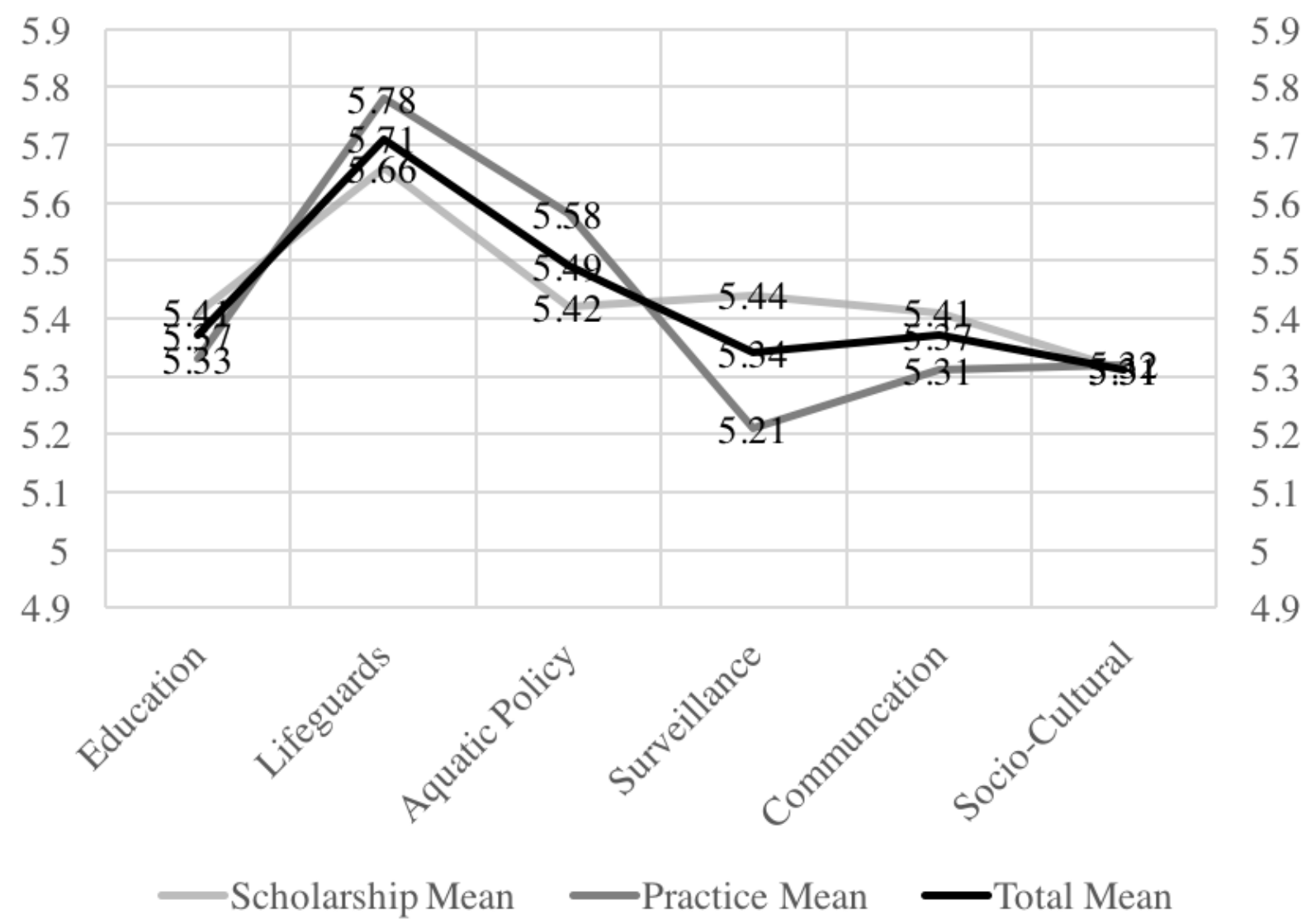

Figure 3. Variations in ratings between categories. This figure illustrates the variability in ratings for each category between sample sub-groups (Education= Education and Programming Effectiveness; Lifeguards = Lifeguard Protocols and Victim Recognition; Aquatic Policy = Aquatic Policy and Safety; Surveillance $=$ Surveillance Data; Communication $=$ Communication and Public Awareness; Socio-Cultural = Socio-Cultural and Demographic Factors). 
Table 1

Expert Panel Demographics

\begin{tabular}{ccccccc}
\hline & \multicolumn{2}{c}{ Round 1 } & \multicolumn{2}{c}{ Round 2 } & \multicolumn{2}{c}{ Round 3 } \\
\hline Age & Scholarship & Practice & Scholarship & Practice & Scholarship & Practice \\
Range & Group & Group & Group & Group & Group & Group \\
& N(\%) & N(\%) & N(\%) & N(\%) & N(\%) & N(\%) \\
\hline $18-25$ & $0(0 \%)$ & $0(0 \%)$ & $0(0 \%)$ & $0(0 \%)$ & $0(0 \%)$ & $0(0 \%)$ \\
\hline $26-35$ & $3(7 \%)$ & $7(26 \%)$ & $2(8 \%)$ & $3(19 \%)$ & $1(4 \%)$ & $3(17 \%)$ \\
\hline $36-45$ & $7(16 \%)$ & $3(11 \%)$ & $5(19 \%)$ & $3(19 \%)$ & $4(17 \%)$ & $3(17 \%)$ \\
\hline $46-55$ & $9(21 \%)$ & $10(37 \%)$ & $3(12 \%)$ & $8(50 \%)$ & $4(17 \%)$ & $8(44 \%)$ \\
\hline $55-65$ & $12(28 \%)$ & $3(11 \%)$ & $8(31 \%)$ & $1(6 \%)$ & $8(33 \%)$ & $2(11 \%)$ \\
\hline $66+$ & $12(28 \%)$ & $4(15 \%)$ & $8(31 \%)$ & $1(6 \%)$ & $7(29 \%)$ & $2(11 \%)$ \\
\hline Total & $43(100 \%)$ & $27(100 \%)$ & $26(100 \%)$ & $16(100 \%)$ & $24(100 \%)$ & $18(100 \%)$ \\
\hline Gender & & & & & \\
\hline Male & $27(63 \%)$ & $15(55 \%)$ & $16(62 \%)$ & $7(44 \%)$ & $17(71 \%)$ & $9(50 \%)$ \\
\hline Female & $16(37 \%)$ & $12(45 \%)$ & $10(38 \%)$ & $9(56 \%)$ & $7(29 \%)$ & $9(50 \%)$ \\
\hline Total & $43(100 \%)$ & $27(100 \%)$ & $26(100 \%)$ & $16(100 \%)$ & $24(100 \%)$ & $18(100 \%)$ \\
\hline
\end{tabular}


Table 2.

Priority Research Questions

\begin{tabular}{|c|c|c|c|c|c|}
\hline \# & Question & $\frac{\text { Total }}{\text { Mean }}$ & $\frac{\text { Scholarship }}{\underline{\text { Mean }}}$ & $\frac{\text { Practice }}{\underline{\text { Mean }}}$ & $\frac{\text { Difference }}{\underline{\text { Between }}}$ \\
\hline 1 & $\begin{array}{l}\text { What strategies are most effective in } \\
\text { increasing parental supervision of } \\
\text { children around bodies of water? }\end{array}$ & 6.42 & 6.48 & 6.35 & 0.13 \\
\hline 2 & $\begin{array}{l}\text { What can be done to increase public } \\
\text { recognition of drowning as a public } \\
\text { health issue? }\end{array}$ & 6.24 & 6.48 & 5.88 & 0.60 \\
\hline 3 & $\begin{array}{l}\text { What impact does parent education of } \\
\text { water safety have on child drowning } \\
\text { prevention? }\end{array}$ & 6.15 & 6.05 & 6.29 & 0.24 \\
\hline 4 & $\begin{array}{l}\text { What can be done to increase parental } \\
\text { supervision when lifeguards are } \\
\text { present? }\end{array}$ & 6.15 & 6.09 & 6.24 & 0.15 \\
\hline 5 & $\begin{array}{l}\text { Are lifeguards and parents effective at } \\
\text { recognizing a drowning victim and } \\
\text { what can be done to increase victim } \\
\text { recognition? }\end{array}$ & 6.12 & 6.35 & 5.82 & 0.53 \\
\hline 6 & $\begin{array}{l}\text { What do parents/caregivers believe } \\
\text { their role is in an aquatic environment? }\end{array}$ & 6.03 & 6.00 & 6.06 & 0.06 \\
\hline 7 & $\begin{array}{l}\text { What role do different levels of water } \\
\text { competence (a.k.a., swimming skill } \\
\text { level) play in preventing fatal and non- } \\
\text { fatal drownings? }\end{array}$ & 6.02 & 6.17 & 5.83 & 0.34 \\
\hline 8 & $\begin{array}{l}\text { Is there a significant difference } \\
\text { between drowning rates when } \\
\text { lifeguards are present? }\end{array}$ & 6.02 & 6.00 & 6.06 & 0.06 \\
\hline 9 & $\begin{array}{l}\text { What, if any, effect does including } \\
\text { water safety in a K- } 12 \text { school's } \\
\text { curriculum have on the reduction of } \\
\text { drowning risk? }\end{array}$ & 6.00 & 6.23 & 5.71 & 0.52 \\
\hline
\end{tabular}


Table 3.

Education and Programming Effectiveness

\begin{tabular}{|c|c|c|c|c|c|}
\hline \# & Question & $\frac{\text { Total }}{\text { Mean }}$ & $\frac{\text { Scholarship }}{\text { Mean }}$ & $\frac{\text { Practice }}{\underline{\text { Mean }}}$ & $\frac{\underline{\text { Difference }}}{\underline{\text { Between }}}$ \\
\hline 3 & $\begin{array}{l}\text { What impact does parent education of } \\
\text { water safety have on child drowning } \\
\text { prevention? }\end{array}$ & 6.15 & 6.05 & 6.29 & 0.24 \\
\hline 9 & $\begin{array}{l}\text { What, if any, effect does including } \\
\text { water safety in a K-12 school's } \\
\text { curriculum have on the reduction of } \\
\text { drowning risk? }\end{array}$ & 6 & 6.23 & 5.71 & 0.52 \\
\hline 14 & $\begin{array}{l}\text { What water safety information needs to } \\
\text { be included in learn to swim programs? }\end{array}$ & 5.74 & 5.86 & 5.59 & 0.27 \\
\hline 18 & $\begin{array}{l}\text { What are critical skills are needed for } \\
\text { self-rescue? }\end{array}$ & 5.69 & 5.82 & 5.53 & 0.29 \\
\hline 21 & $\begin{array}{l}\text { How can the effectiveness of drowning } \\
\text { prevention education programs be } \\
\text { measured? }\end{array}$ & 5.64 & 5.59 & 5.71 & 0.12 \\
\hline 26 & $\begin{array}{l}\text { What effective approaches to teaching } \\
\text { drowning prevention and water safety } \\
\text { education in K-12 schools across the } \\
\text { U.S.? }\end{array}$ & 5.57 & 5.64 & 5.47 & 0.17 \\
\hline 29 & $\begin{array}{l}\text { When and where is the most effective } \\
\text { time and place to provide drowning } \\
\text { prevention/water safety education to all } \\
\text { ages? }\end{array}$ & 5.51 & 5.45 & 5.59 & 0.14 \\
\hline 30 & $\begin{array}{l}\text { What is the best age to begin children's } \\
\text { swim lessons? }\end{array}$ & 5.49 & 5.45 & 5.53 & 0.08 \\
\hline 32 & $\begin{array}{l}\text { What barriers exist for drowning } \\
\text { prevention and water safety education } \\
\text { in K-12 schools across the U.S.? }\end{array}$ & 5.42 & 5.50 & 5.31 & 0.19 \\
\hline 35 & $\begin{array}{l}\text { What are the components for effective } \\
\text { learn to swim and water safety } \\
\text { programming for adolescents and } \\
\text { adults? }\end{array}$ & 5.41 & 5.32 & 5.53 & 0.21 \\
\hline 41 & $\begin{array}{l}\text { What programs/initiatives, besides } \\
\text { mandatory requirements and federal } \\
\text { regulations, can be enacted to reduce } \\
\text { drowning deaths in the U.S.? }\end{array}$ & 5.34 & 5.41 & 5.25 & 0.16 \\
\hline 43 & $\begin{array}{l}\text { At what age group (i.e. children, or } \\
\text { parents, or grandparents) should } \\
\text { drowning prevention education be }\end{array}$ & 5.33 & 5.36 & 5.29 & 0.07 \\
\hline
\end{tabular}




\begin{tabular}{|c|c|c|c|c|c|}
\hline & $\begin{array}{l}\text { focused on or is there a best way to } \\
\text { educate all ages simultaneously? }\end{array}$ & & & & \\
\hline 47 & $\begin{array}{l}\text { How often do water safety skills and } \\
\text { information need to be refreshed to } \\
\text { retain the knowledge and skills in an } \\
\text { emergency situation by lay responders? }\end{array}$ & 5.28 & 5.23 & 5.35 & 0.12 \\
\hline 48 & $\begin{array}{l}\text { What current resources exist to educate } \\
\text { the public on drowning prevention and } \\
\text { are those resources effective? }\end{array}$ & 5.26 & 5.18 & 5.35 & 0.17 \\
\hline 50 & $\begin{array}{l}\text { In what ways can drowning } \\
\text { prevention/water safety information be } \\
\text { effectively delivered as part of a } \\
\text { parenting course? }\end{array}$ & 5.24 & 5.23 & 5.25 & 0.02 \\
\hline 53 & $\begin{array}{l}\text { Are swim lessons or alternative } \\
\text { educational approaches the best way to } \\
\text { provide water safety education? }\end{array}$ & 5.21 & 5.27 & 5.12 & 0.15 \\
\hline 58 & $\begin{array}{l}\text { What is the reach and scope of current } \\
\text { drowning prevention/water safety } \\
\text { education programs in the U.S.? }\end{array}$ & 5.18 & 5.09 & 5.29 & 0.20 \\
\hline 62 & $\begin{array}{l}\text { What are the perceived barriers and } \\
\text { facilitators to learning to swim in the } \\
\text { U.S.? }\end{array}$ & 5.15 & 5.36 & 4.88 & 0.48 \\
\hline 63 & $\begin{array}{l}\text { What are the positive and negative } \\
\text { effects of infant based water survival } \\
\text { training? }\end{array}$ & 5.13 & 5.45 & 4.71 & 0.74 \\
\hline 67 & $\begin{array}{l}\text { What are parent perceptions of and } \\
\text { motivations for enrolling a child in } \\
\text { swim lessons? }\end{array}$ & 5.11 & 5.27 & 4.87 & 0.40 \\
\hline 68 & $\begin{array}{l}\text { What protective effects (if any) against } \\
\text { drowning exist after swim } \\
\text { lessons/learning to swim remain across } \\
\text { the lifespan? }\end{array}$ & 5.08 & 4.86 & 5.53 & 0.67 \\
\hline 71 & $\begin{array}{l}\text { What are the positive and negative } \\
\text { effects of short duration swimming } \\
\text { lessons on drowning prevention } \\
\text { knowledge and water safety skills? }\end{array}$ & 5.05 & 5.27 & 4.76 & 0.30 \\
\hline 72 & $\begin{array}{l}\text { What is the prevalence and impact of } \\
\text { "water-watcher" programs in the U.S.? }\end{array}$ & 5.05 & 5.18 & 4.88 & 0.51 \\
\hline 81 & $\begin{array}{l}\text { How does one address the panic } \\
\text { component of non-intentional } \\
\text { immersion in structured learned to swim } \\
\text { lessons? }\end{array}$ & 5.00 & 4.95 & 5.06 & 0.11 \\
\hline
\end{tabular}


Table 4.

Lifeguard Protocols and Victim Recognition

\begin{tabular}{|c|c|c|c|c|c|}
\hline \# & Question & $\frac{\text { Total }}{\text { Mean }}$ & $\frac{\text { Scholarship }}{\underline{\text { Mean }}}$ & $\frac{\text { Practice }}{\text { Mean }}$ & $\frac{\text { Difference }}{\underline{\text { Between }}}$ \\
\hline 5 & $\begin{array}{l}\text { Are lifeguards and parents effective at } \\
\text { recognizing a drowning victim and } \\
\text { what can be done to increase victim } \\
\text { recognition? }\end{array}$ & 6.12 & 6.35 & 5.82 & 0.53 \\
\hline 8 & $\begin{array}{l}\text { Is there a significant difference } \\
\text { between drowning rates when } \\
\text { lifeguards are present? }\end{array}$ & 6.02 & 6.00 & 6.06 & 0.06 \\
\hline 10 & $\begin{array}{l}\text { What evidence-based training } \\
\text { methods, techniques, protocols, and } \\
\text { practices exist for lifeguards in the } \\
\text { U.S.? }\end{array}$ & 5.84 & 5.95 & 5.69 & 0.26 \\
\hline 11 & $\begin{array}{l}\text { How effective are lifeguard audits at } \\
\text { increasing lifeguard vigilance? }\end{array}$ & 5.81 & 5.77 & 5.87 & 0.10 \\
\hline 12 & $\begin{array}{l}\text { What is a safe time duration of time } \\
\text { for lifeguards to be on-duty? }\end{array}$ & 5.79 & 5.45 & 6.25 & 0.80 \\
\hline 15 & $\begin{array}{l}\text { Is there a correlation between the age } \\
\text { of a lifeguard and their scanning } \\
\text { effectiveness? }\end{array}$ & 5.74 & 5.64 & 5.88 & 0.19 \\
\hline 16 & $\begin{array}{l}\text { How many drownings occur each } \\
\text { year at locations where lifeguards are } \\
\text { present? }\end{array}$ & 5.74 & 5.82 & 5.63 & 0.24 \\
\hline 44 & $\begin{array}{l}\text { What protocols exist for having } \\
\text { lifeguards on duty during educational } \\
\text { courses and events? }\end{array}$ & 5.32 & 5.23 & 5.44 & 0.21 \\
\hline 78 & $\begin{array}{l}\text { How can the study of brain } \\
\text { development be used to improve the } \\
\text { effectiveness of young lifeguard's } \\
\text { decision making and surveillance } \\
\text { duties? }\end{array}$ & 5.03 & 4.77 & 5.38 & 0.61 \\
\hline
\end{tabular}


Table 5.

Aquatic Policy and Safety

\begin{tabular}{|c|c|c|c|c|c|}
\hline \# & Question & $\frac{\text { Total }}{\text { Mean }}$ & $\frac{\text { Scholarship }}{\underline{\text { Mean }}}$ & $\frac{\text { Practice }}{\underline{\text { Mean }}}$ & $\frac{\underline{\text { Difference }}}{\underline{\text { Between }}}$ \\
\hline 1 & $\begin{array}{l}\text { What strategies are most effective in } \\
\text { increasing parental supervision of } \\
\text { children around bodies of water? }\end{array}$ & 6.42 & 6.48 & 6.35 & 0.13 \\
\hline 4 & $\begin{array}{l}\text { What can be done to increase parental } \\
\text { supervision when lifeguards are present? }\end{array}$ & 6.15 & 6.09 & 6.24 & 0.15 \\
\hline 6 & $\begin{array}{l}\text { What do parents/caregivers believe their } \\
\text { role is in an aquatic environment? }\end{array}$ & 6.03 & 6.00 & 6.06 & 0.06 \\
\hline 23 & $\begin{array}{l}\text { What strategies can increase usage of } \\
\text { personal flotation devices (PFDs) among } \\
\text { boaters and swimmers? }\end{array}$ & 5.61 & 5.45 & 5.81 & 0.36 \\
\hline 31 & $\begin{array}{l}\text { How can the use of drowning prevention } \\
\text { and water safety technology increase? }\end{array}$ & 5.45 & 5.23 & 5.75 & 0.52 \\
\hline 36 & $\begin{array}{l}\text { To what extent are specific variables } \\
\text { (i.e. supervision, drug and alcohol use, } \\
\text { prior convictions, conditions of water, } \\
\text { prevention and rescue training, time } \\
\text { child was missing) associated with } \\
\text { drowning? }\end{array}$ & 5.39 & 5.18 & 5.69 & 0.29 \\
\hline 37 & $\begin{array}{l}\text { What are layers of protection around } \\
\text { swimming pools and which layers are } \\
\text { most effective at reducing or preventing } \\
\text { drowning? }\end{array}$ & 5.39 & 5.27 & 5.56 & 0.51 \\
\hline 51 & $\begin{array}{l}\text { To what extent is underwater breath } \\
\text { holding dangerous? }\end{array}$ & 5.24 & 5.45 & 4.93 & 0.56 \\
\hline 52 & $\begin{array}{l}\text { Are current regulations surrounding } \\
\text { entrapment prevention, fencing } \\
\text { requirements, and other similar barriers } \\
\text { effective at reducing drowning and } \\
\text { aquatic injuries/fatalities? }\end{array}$ & 5.24 & 5.00 & 5.56 & 0.52 \\
\hline 55 & $\begin{array}{l}\text { What requirements exist by state health } \\
\text { and physical education } \\
\text { standards/objectives regarding water } \\
\text { safety/drowning prevention education? }\end{array}$ & 5.21 & 5.14 & 5.31 & 0.17 \\
\hline 64 & $\begin{array}{l}\text { Have environmental, behavioral, and } \\
\text { legislative or regulatory interventions } \\
\text { reduced fatal/non-fatal drownings? }\end{array}$ & 5.13 & 5.05 & 5.25 & 0.20 \\
\hline 69 & $\begin{array}{l}\text { In regards to lightning what is a } \\
\text { reasonable policy in both an outdoor and } \\
\text { indoor environment? }\end{array}$ & 5.08 & 5.36 & 4.69 & 0.67 \\
\hline
\end{tabular}




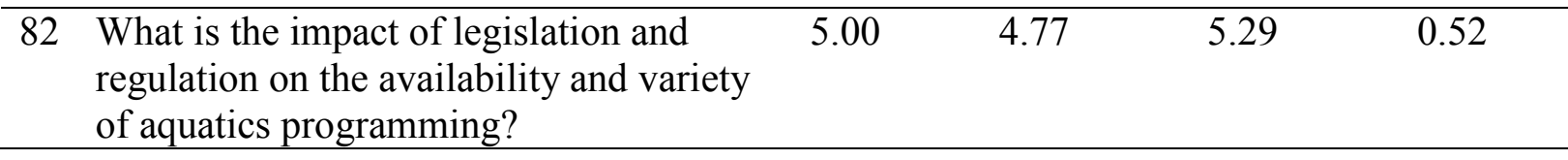


Table 6.

Surveillance Data

\begin{tabular}{|c|c|c|c|c|c|}
\hline \# & Question & $\underline{\text { Total }}$ & $\frac{\text { Scholarship }}{\underline{\text { Mean }}}$ & $\frac{\text { Practice }}{\text { Mean }}$ & $\frac{\text { Difference }}{\underline{\text { Between }}}$ \\
\hline 13 & $\begin{array}{l}\text { What are the most common } \\
\text { drowning/accidents in aquatic } \\
\text { environments? }\end{array}$ & 5.76 & 5.73 & 5.81 & 0.08 \\
\hline 17 & $\begin{array}{l}\text { What aquatic environments (i.e., pool, } \\
\text { spa, lake, river, ocean) have the greatest } \\
\text { number of aquatic injuries/fatalities? }\end{array}$ & 5.70 & 5.68 & 5.73 & 0.05 \\
\hline 20 & $\begin{array}{l}\text { How effective are PFDs at reducing the } \\
\text { risk of drowning for low ability and non- } \\
\text { swimmers? }\end{array}$ & 5.66 & 5.55 & 5.81 & 0.26 \\
\hline 22 & $\begin{array}{l}\text { What are the potential barriers and } \\
\text { benefits to the implementation of a } \\
\text { universal data collection system at the } \\
\text { national level, or inclusion of drownings } \\
\text { into existing trauma databases at the } \\
\text { state and national level? }\end{array}$ & 5.63 & 5.95 & 5.19 & 0.76 \\
\hline 24 & $\begin{array}{l}\text { How can more robust surveillance data } \\
\text { be collected from first responders who } \\
\text { respond to a drowning victim? }\end{array}$ & 5.58 & 5.73 & 5.38 & 0.35 \\
\hline 25 & $\begin{array}{l}\text { How can the accuracy of current } \\
\text { statistics on fatal and non-fatal } \\
\text { drownings in the U.S. be improved? }\end{array}$ & 5.58 & 5.86 & 5.19 & 0.67 \\
\hline 45 & $\begin{array}{l}\text { How are different levels of water } \\
\text { competency associated with drowning } \\
\text { risk in different aquatic environments } \\
\text { and water conditions? }\end{array}$ & 5.32 & 5.18 & 5.50 & 0.32 \\
\hline 46 & $\begin{array}{l}\text { Are there specific regions or local areas } \\
\text { where drowning rates have decreased } \\
\text { significantly, and if so why? }\end{array}$ & 5.29 & 5.41 & 5.13 & 0.28 \\
\hline 54 & $\begin{array}{l}\text { What is the impact of local } \\
\text { coalitions/task forces on the reduction of } \\
\text { water-related injuries/fatalities? }\end{array}$ & 5.21 & 5.18 & 5.24 & 0.06 \\
\hline 59 & $\begin{array}{l}\text { What is the economic and societal } \\
\text { impact of nonfatal drowning? }\end{array}$ & 5.16 & 5.32 & 4.94 & 0.38 \\
\hline 66 & $\begin{array}{l}\text { What, if any, correlation exists between } \\
\text { swimming ability and boating-related } \\
\text { fatal and/or non-fatal drowning } \\
\text { incidents? }\end{array}$ & 5.13 & 5.09 & 5.19 & 0.10 \\
\hline 73 & $\begin{array}{l}\text { How robust is the research infrastructure } \\
\text { that supports inquiry and data-driven }\end{array}$ & 5.05 & 5.36 & 4.63 & 0.73 \\
\hline
\end{tabular}


decision-making within the field of drowning prevention?

76 What is the historical trend aquatic injuries and fatalities?

77 What are the economical and societal impact of fatal and non-fatal drownings and aquatic injuries that occur inside of designated swimming areas?

83 Is there a relationship between the trends

$\begin{array}{llll}5.03 & 5.05 & 5.00 & 0.37\end{array}$
of non-fatal drowning injuries (surviving

$\begin{array}{llll}5.03 & 5.18 & 4.81 & 0.05\end{array}$
a drowning) and fatal drownings in specific geographical regions of the U.S.? 
Table 7.

Communication and Public Awareness

\begin{tabular}{|c|c|c|c|c|c|}
\hline \# & Question & $\frac{\text { Total }}{\text { Mean }}$ & $\frac{\text { Scholarship }}{\text { Mean }}$ & $\frac{\text { Practice }}{\underline{\text { Mean }}}$ & $\frac{\text { Difference }}{\underline{\text { Between }}}$ \\
\hline 2 & $\begin{array}{l}\text { What can be done to increase public } \\
\text { recognition of drowning as a public } \\
\text { health issue? }\end{array}$ & 6.24 & 6.48 & 5.88 & 0.60 \\
\hline 19 & $\begin{array}{l}\text { What content/messaging would have } \\
\text { the greatest impact on the public at- } \\
\text { large regarding water safety and } \\
\text { reducing the incidence of drowning? }\end{array}$ & 5.68 & 5.64 & 5.75 & 0.11 \\
\hline 39 & $\begin{array}{l}\text { How effective is educating the general } \\
\text { public on drowning prevention and } \\
\text { water safety through government } \\
\text { agencies (i.e. CPSC, CDC, State Health } \\
\text { Departments, ect.)? }\end{array}$ & 5.37 & 5.27 & 5.5 & 0.23 \\
\hline 40 & $\begin{array}{l}\text { How can similar successful safety and } \\
\text { prevention campaigns (i.e. fire } \\
\text { prevention, seatbelt safety, ect.) be } \\
\text { replicated for the purpose of drowning } \\
\text { prevention? }\end{array}$ & 5.37 & 5.27 & 5.5 & 0.23 \\
\hline 56 & $\begin{array}{l}\text { Can a national message surrounding } \\
\text { water safety and drowning prevention } \\
\text { education be developed? }\end{array}$ & 5.21 & 5.32 & 5.06 & 0.26 \\
\hline 57 & $\begin{array}{l}\text { What is a practical definition of } \\
\text { supervision around water? }\end{array}$ & 5.21 & 5.32 & 5.06 & 0.26 \\
\hline 61 & $\begin{array}{l}\text { How effective are visual sign (i.e. } \\
\text { safety signage, flags, ect.) at preventing } \\
\text { drowning and aquatic injury? }\end{array}$ & 5.16 & 5.32 & 4.94 & 0.38 \\
\hline 75 & $\begin{array}{l}\text { What strategies can increase public } \\
\text { awareness around the risk of bathtub } \\
\text { drownings? }\end{array}$ & 5.03 & 5.00 & 5.06 & 0.05 \\
\hline 79 & $\begin{array}{l}\text { What is the best definition of drowning } \\
\text { in relation to physiology, public health, } \\
\text { injury prevention, and other related } \\
\text { fields? }\end{array}$ & 5.03 & 5.05 & 5.00 & 0.06 \\
\hline
\end{tabular}


Table 8.

Socio-Cultural and Demographic Factors

\begin{tabular}{|c|c|c|c|c|c|}
\hline \# & Question & $\frac{\text { Total }}{\text { Mean }}$ & $\frac{\text { Scholarship }}{\underline{\text { Mean }}}$ & $\frac{\text { Practice }}{\underline{\text { Mean }}}$ & $\frac{\underline{\text { Difference }}}{\underline{\text { Between }}}$ \\
\hline 7 & $\begin{array}{l}\text { What role do different levels of water } \\
\text { competence (a.k.a., swimming skill } \\
\text { level) play in preventing fatal and non- } \\
\text { fatal drownings? }\end{array}$ & 6.02 & 6.17 & 5.83 & 0.34 \\
\hline 27 & $\begin{array}{l}\text { What are the most effective methods to } \\
\text { teach self-rescue at various ages and } \\
\text { stages of ability? }\end{array}$ & 5.54 & 5.45 & 5.64 & 0.19 \\
\hline 28 & $\begin{array}{l}\text { What is the specific age (range) when } \\
\text { swim lessons have the most protective } \\
\text { effect against drowning for children? }\end{array}$ & 5.51 & 5.41 & 5.65 & 0.24 \\
\hline 33 & $\begin{array}{l}\text { What are the most effective } \\
\text { communication strategies at reaching } \\
\text { specific target groups (i.e. gender, race, } \\
\text { cultural background, special } \\
\text { populations)? }\end{array}$ & 5.42 & 5.59 & 5.19 & 0.40 \\
\hline 34 & $\begin{array}{l}\text { What drowning prevention education } \\
\text { initiatives/strategies can effectively } \\
\text { focus on diverse populations? }\end{array}$ & 5.42 & 5.55 & 5.25 & 0.30 \\
\hline 38 & $\begin{array}{l}\text { How can universal learn to swim } \\
\text { initiatives among preschool age children } \\
\text { be encouraged and taught especially in } \\
\text { minority communities? }\end{array}$ & 5.39 & 5.45 & 5.31 & 0.14 \\
\hline 42 & $\begin{array}{l}\text { What drowning prevention education } \\
\text { initiatives/strategies can effectively } \\
\text { focus on adults? }\end{array}$ & 5.34 & 5.27 & 5.44 & 0.17 \\
\hline 49 & $\begin{array}{l}\text { How does the lack of an American } \\
\text { College of Surgeons trauma } \\
\text { classification for drowning limit the } \\
\text { understanding of data and the } \\
\text { implementation of evidence-based injury } \\
\text { prevention programs? }\end{array}$ & 5.26 & 5.18 & 5.38 & 0.20 \\
\hline 60 & $\begin{array}{l}\text { What additional information and } \\
\text { training is required for current water } \\
\text { safety instructors/programs to be } \\
\text { effective in teaching water } \\
\text { safety/swimming to children with } \\
\text { special needs? }\end{array}$ & 5.16 & 5.27 & 5.00 & 0.27 \\
\hline 65 & $\begin{array}{l}\text { How effective is drowning prevention } \\
\text { education programming with special }\end{array}$ & 5.13 & 5.00 & 5.31 & 0.31 \\
\hline
\end{tabular}


populations (i.e. autism, intellectual

disabilities, and specific

racial/ethnic/cultural backgrounds)?

$\begin{array}{llllll}70 & \text { What demographic group (age, } & 5.08 & 4.86 & 5.40 & 0.54\end{array}$ socioeconomic, gender, race, cultural) is at the greatest risk of drowning?

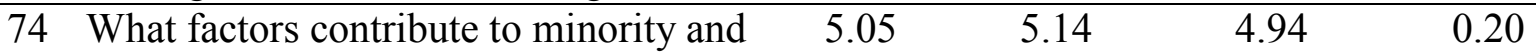
low income children drowning rates compared to same aged peers?

\begin{tabular}{llllll}
\hline 80 & $\begin{array}{l}\text { To what extent do specific cultural } \\
\text { issues impact the effectiveness of } \\
\text { drowning prevention education and the } \\
\text { use of safe practices? }\end{array}$ & 5.03 & 5.09 & 4.94 & 0.15 \\
\hline 84 & $\begin{array}{l}\text { What percentage of the U.S. population, } \\
\text { by age group, has a basic understanding } \\
\text { of water safety AND water safety skills? }\end{array}$ & & & & \\
\hline
\end{tabular}




\section{Appendix A}

\section{Extended Literature Review}

\section{Review of Literature: Injury Surveillance on Drowning}

Drowning is a worldwide epidemic; globally, drowning is one of the leading causes of unintentional injury-related death among all age ranges, and is the leading cause of unintentional injury-related death for children. According to the World Health Organization (WHO) drowning is estimated to claim the lives of an estimated 372,000 people each year, with over ninety percent (92\%) of these deaths occurring in low- and middle-income countries (WHO, 2014). The United States is classified as a high-income country and experiences a relatively lower number of drowning fatalities on an annual basis in comparison to low- and middle-income countries; however, drowning remains a significant public health issue. Education on injury prevention has been and remains a key public health strategy. Research on the design, application, and effectiveness of drowning prevention education is minimal within the United States. The purpose of this intended study is to develop consensus among experts on future research endeavors are needed to strengthen educational initiatives. Through consensus, a plan can be formulated to strengthen drowning prevention education within the United States to create a better-informed public.

Foundational, seminal, and recent research on drowning and prevention education does exist worldwide and has been reviewed for this intended study. First by reviewing injury surveillance of drowning including a) the drowning process, b) drowning statistics, and c) an examination of high risk populations, an understanding of drowning as a public health issue becomes clear. Next a review of drowning prevention education research including a) water safety instruction, b) children and water safety, c) parents and water safety, and d) current 
instructional recommendation, the current state of drowning prevention education in highincome countries is formed. Lastly, research surrounding issues in drowning surveillance and drowning prevention education research is examined including a) data collection and statistical analysis challenges and b) a comparison to the chaos in the brick yard theory. Through consensus building among experts using a Delphi method, a clear research agenda will be developed to reduce the number of unintentional drowning injuries and fatalities through education.

\section{The Drowning Process}

The World Congress on Drowning (2002) defined drowning as "the process of experiencing respiratory impairment from submersion/immersion in liquid.” Additionally, Golden, Tipton, and Scott (1997) define drowning as "suffocation by submersion, especially in water." The drowning process is also described by Vittone and Pia (2006) and Pia (1974) as the "instinctive drowning response" (IDR). The IDR is broken down into five distinct parts; (1) unable to call out for help; (2) person's mouth will sink below and reappear above the water surface; (3) drowning person cannot wave for help; (4) involuntary control of arm action; (5) person remains upright in the water with no supporting kick and can only maintain this struggle for 20-60 seconds before submerging (Vittone \& Pia, 2006; Pia, 1974). Pia (1982) also developed the "R.I.D. Factor, which stands for recognition, intrusion, and distraction, which he states are the reasons why someone would drown when a lifeguard is on duty. This concept is also relatable to anyone who is charged with watching the water. If someone is drowning and it goes unnoticed, the person who should have been watching failed to recognize the drowning, let another duty intrude on their responsibility to watch the water, and/or was distracted from watching the water (Pia, 1982). 
The American Red Cross Scientific Advisory Council Aquatic Sub-group has broken drowning down into two separate processes that represent drowning prevention (drowning intervention) and drowning response (secondary prevention) (Ramos et al., 2015). The primary drowning intervention includes safety steps to prevent drowning from occurring including swimming near a lifeguard, providing constant attention to children you are supervising, fencing the pool, requiring inexperienced swimmers to wear a lifejacket, and learning to swim. The secondary prevention covers the emergency response steps once a drowning occurs. This includes recognition of the drowning victim, rescue and removal of the person from the water, calling emergency services personnel, beginning cardiopulmonary resuscitation (CPR), and using an automated external defibrillator (AED; Ramos et al., 2015).

Moran (2010) associated drowning risk with the "iceberg phenomena." Though at the surface, drowning statistics in regards to mortality and morbidity (fatal drowning) seem to be relatively small in comparison to other categories, what lurks below the surface shows that drowning is a much larger problem. Below the surface, three different categories emerge; nomorbidity drowning (non-fatal hospital care), self-reported life-threatening experiences, and exposure to risk through aquatic recreation (Moran, 2010). Though fatal drowning statistics are usually spotlighted, understanding that all persons have an inherent drowning risk is important to fully comprehend the risk that drowning poses and the importance of drowning prevention. Education on the prevention of drowning must reflect this.

\section{Drowning Statistics}

In the United States, drowning is classified by the Centers for Disease Control and Prevention (CDC) as an injury related death. Drowning is the leading cause of unintentional injury related death for children ages 1-4, and is in the top 5 causes of injury related death for 
children 1-14 in the United States. In the year 2010, there were a reported 3,782 drowning deaths between all age ranges in the United States (Murphy, Xu, \& Kochanek, 2013), a rate of 1.22 per 100,000 (CDC, 2013). From 2005-2009, an average of 3,880 persons in the U.S. were victims of fatal drowning, and an estimated 5,789 persons received hospital care for a non-fatal drowning every year (Drowning, 2012). It was also found that males $(2.07$ per 100,000) had almost four times greater drowning risk than females (0.54 per 100,000) (Drowning, 2012).

The World Health Organization's (WHO) 2014 Global Drowning Report (GDR) indicates that high-income countries have made a significant impact on reducing the number of drownings. Topographically, this seems to hold true. In an editorial, Langendorfer (2011) points out that the number of drowning fatalities in high-income countries has steadily declined over the past 30-50 years. The United States did not show a dramatic decrease in drowning fatalities or drowning related non-fatal injuries when comparing data from the year 2000 to the year 2010. In the year 2000 the United States saw 3,482 drowning deaths (1.24 per 100,000) and a decade later in 2010 there were 3,782 drowning deaths (1.22 per 100,000). In 2000 there were 7,840 reported non-fatal drowning injuries 95\% CI [3,655, 12,025] (2.80 per 100,000) and in 2010 there were 7,306 reported non-fatal drowning injuries 95\% CI [4,383, 10,229] $(2.48$ per 100,000). Taking into account that a non-fatal drowning injury could leave the victim severely impaired, it is important to take these statistics into consideration. When population increases are taken into account, a small decline is noted; however it is not reported as significant or dramatic (CCD, 2013).

Cost of injuries and fatalities over a lifetime is another figure used to represent the severity of the problem. For 2010 in the United States, the estimated combined cost (Medical and Work Loss) of fatal drownings was $\$ 4,748,065,000$; the estimated combined cost non-fatal 
drowning injuries with hospitalizations was $\$ 1,267,717,000$; and the estimated cost of non-fatal drowning injuries only receiving emergency department care was $\$ 5,942,000$. This means that the total costs of all reported drownings (fatalities, hospitalized non-fatal drownings, and only emergency department care non-fatal drownings) was \$6,021,726,000 for 2010 (CDC, 2013).

Questions still remain on what high-income countries, such as the United States, need to accomplish to see a dramatic or significant reduction in their drowning rate again. Much like a marathon runner "hitting the wall," high income countries seem to have a hit a wall to significantly reducing the number of unintentional drowning deaths. Linking to the WHO's GDR's recommendation of future research addressing the outstanding questions to reduce drowning; this study sets out to form expert consensus on outstanding research questions in the area of drowning prevention education. These research questions will need to be addressed to make a significant impact reducing number of unintentional drowning related deaths and injuries in the United States.

\section{Higher Risk Populations}

High risk populations in relation to drowning have been identified by the CDC and through extensive research surrounding localized drowning rates including minority communities, immigrant populations and individuals with disabilities. The CDC reports that minorities have a significantly higher fatal drowning rate. African Americans in the 5-19 age range drown in swimming pools at rates 5.5 times that of Caucasian children (CDC, 2014). Irwin, Irwin, Ryan, and Drayer (2009a, 2009b) conducted a study ( $n=1680)$ to examine the risk factors associated with race. Fifty-eight percent (57.5\%) of African American and fifty six percent $(56.2 \%)$ of Hispanic and Latino respondents self-reported having a high risk around 
water by not being comfortable in deep water and being unable to swim as compared to only $30.9 \%$ of Caucasians perceiving high risks.

Research across North America (Lifesaving Society of Canada, 2010) has found that in some localized areas, certain sub-sets of the populations have a higher drowning rate. Lack of swimming skills have been found to be related to low socio- economic conditions, cultural differences, and a high immigrant population (Fralick, Gallinger, \& Hwang, 2013; Golob, Giles \& Rich, 2013; Martin \& Witman, 2010). The Lifesaving Society of Canada (2010) released preliminary research findings that showed that $31 \%$ of "new Canadians" (immigrants) are nervous around the water and $50 \%$ of new Canadian parents fear their child could drown. A disproportionate racial trend/pattern has shown that some minority populations are likely to have lower swimming abilities and a higher likelihood of drowning. Since research points to both a perceived and literal risk for minority communities and high immigrant populations, identification of solutions in regards to high risk populations is critical.

Sbarbaro and Enyeart Smith (2011) looked at the experience middle school children have towards water safety. Using a water safety survey administered to seventh, eighth, and ninth grade students $(n=122)$, which included children of migrant families as well as economically disadvantaged students the researchers analyzed how middle school students assess their own water safety risk. Researchers found that Hispanic children were less likely to wear a lifejacket or another personal floatation device (PFD) $(\mathrm{p}<.001)$ when compared to white children or other races. The researchers also found a signification relationship $(\mathrm{p}<.05)$ between ethnicity and improving swimming skills as a barrier to swimming. (Sbarbaro \& Enyeart Smith, 2011). These results are important since minority communities are often attributed with having a much higher drowning risk that their Caucasian counterparts. 
In addition to minority and immigrant populations, individuals with disabilities also have been found to be at a higher of drowning. Grosse (2014) explored aquatic safety issues with individuals with autism syndrome disorders (ASD) who are at a much higher risk of drowning and other unintentional injury related deaths (Grosse, 2014). Several studies have been completed to determine a standardized mortality ratio (SMR) for children with autism and their risk of drowning. SMR is calculated using the observed number of deaths to the expected number of deaths, resulting in any number higher than 1.0 shows that the observed death rate for a specific population exceeded expectations. Studies have shown that for individuals with ASD and mild to no intellectual disability the SMR for drowning was 3.9 and for moderate, severe, or profound intellectual disability the SMR for drowning was 13.71 (Myers, n.d., para 4).

\section{Review of Literature: Drowning Prevention Education}

This current studies focuses is solely on the United States; however significant amounts of research surrounding water safety and drowning prevention have been conducted outside of the United States. These studies are included in this review of literature for the purpose of further understanding what type of research have been completed and what relation their results have to the United States. Education is a key prevention strategy when it comes to the prevention of injuries and fatalities in relation to drowning (Center for Disease Control and Prevention, 2014). Research surrounding: a) best practices in water safety instruction, b) children and water safety, c) parents and water safety, and d) the current recommendations on instruction are vital bodies of knowledge to fully gain a perspective of the current state of drowning prevention education.

\section{Water Safety Instruction}

Ramos et al (2015) describes drowning in two stages, prevention and response.

Therefore, this paper focuses on the future research needed to enhance prevention and response 
from an educational standpoint. Understanding response and the statistics are vital information for making informed decisions on appropriate prevention educational content, strategies, and methodology. Inherently, the goal of prevention is to limit the risk of exposure by creating a well-informed public surrounding the risk of drowning. Drowning prevention education is, in many ways a multifaceted approach which includes effective water safety instruction, parent and caregiver knowledge, aquatic and swimming education, and effective response (Ramos et al, 2015).

Effective water safety education is an important component of creating a well-informed public. Blitvich, Moran, Petrass, McElroy, and Stanley (2012) completed a study in Australia to determine swim instructor beliefs surrounding swimming and water safety. Pre-school aquatic instructors $(n=133)$ were surveyed to explore compatibility of instructor messages with accepted drowning prevention beliefs. Over ninety percent (93\%) of instructors reported holding the Austswim TSWS Award for teaching swimming, and an additional $38 \%$ of the instructors held the preschool extension qualification. Eighty-four percent of the instructors surveyed felt that parent supervision was the most important element for safety around the water when a child is swimming. Additionally, $61.5 \%$ of instructors felt that the most important element of toddler swimming lessons was safety, while only $22.3 \%$ felt learning to swim or building confidence in the water were the most important elements. The author's points that these are concerning findings, since safety and learning to swim are not objectives of toddler swimming programs. The cited objectives are only to provide water familiarization and water awareness (Blitvich et al., 2012). These results point to an instructor belief that toddler swimming lessons increase a child safety and additionally teach them to swim. Recommendations from this study included development of a clearer message from instructors and their governing organizations 
surrounding the purpose and objectives of toddler swimming education, in addition to emphasizing parent/adult supervision.

Lynch (2012) discussed that even though the country of Australia has developed strong swimming and water safety educational programs; the country's fatal drowning numbers have plateaued or are on a slight increase every year. Lynch takes the stance that implementing drowning prevention and water safety education into school curriculum would have the most success at making children more aware of swimming safety and drowning prevention. Lynch (2012) further suggests that a lack of qualified instructors may exist and teacher training should consider revisions to include further education for teaching drowning prevention and water safety education

Physical activity is an important aspect in health and physical education in schools, and teaching drowning prevention and water safety could possibly be construed as taking away from this valuable activity time. Cardon, Verstraete, and De Clercq (2004) conducted a study to evaluate the physical activity levels of children in an elementary physical education class. The study compared the levels of physical activity between children in a physical education class that did not involve swimming and a physical education class that did involve swimming $(n=6)$. Results indicated that students were involved in a higher Moderate to Vigorous Physical Activity (MVPA) during a swimming class (52\%) than a non-swimming physical education class (40\%). The swimming portion of the study met the Healthy People 2000 goal of $50 \%$ MVPA being achieved in a physical education lesson (Cardon at al., 2004).

Beale \& Lynn (2011) surveyed Florida physical education instructors $(n=671)$ to determine levels of aquatic physical activity. Results showed that survey respondents had a positive attitude towards aquatic physical activity as part of a physical education curriculum. In 
addition, it was found that $50.9 \%$ of respondents strongly agreed and $41.2 \%$ agreed that promoting drowning prevention was a goal of an aquatic physical activity curriculum.

Physical education and health education teachers are looked upon as a means of teaching both swimming education and drowning prevention education in schools. Sato and Hodge (2012) used a qualitative approach to determine how college-aged African American physical education students $(n=4)$ felt about their aquatic readiness to teach others swimming and water safety. Findings pointed to the participant realizing as minorities, swimming education and the risk of drowning are underappreciated topics. Increased emphasis should be placed on areas such as drowning prevention and need for swimming education in minority populations (Sato \& Hodge, 2012). In other countries (especially in the Pacific) studies have yielded different results when examining college student swimming perceptions and abilities (Moran et al., 2012). Collegiate physical education students $(n=373)$ from New Zealand, Japan and Australia were surveyed on their swimming competencies. This research analyzed what participants cognitively perceived their swimming ability to be using a 20-question researcher designed survey. The survey used self-estimation in six aspects of swimming and survival skills (distance swimming, floatation, swimming on back, dive entries, surface diving, and underwater swim). The results of the survey were compared to the participant's actual swimming abilities. No significant differences were reported between perceived and actual competencies in the water. It was found that females perceived their drowning risk to be significantly higher $(\mathrm{p}=0.016)$ risk of drowning associated with a number of different scenarios presented to them. (Moran et al., 2012).

\section{Children and Water Safety}

Moran (2009a, 2009b) conducted studies with the purpose of starting to understand how children learn about water safety. Moran identifies that there are an abundance of water safety 
and drowning education programs, yet little to no evaluation had been completed to determine if these programs are effective at teaching children water safety. A nationwide survey was conducted among year 11 students $(n=2,202)$ from 41 high schools in New Zealand. Results of the study indicated that there was a significant difference $(\mathrm{p}<.001)$ regarding who influenced male and female students to help them construct their water safety knowledge. It was found that ten times the amount of males compared to female students gain their beliefs towards water safety from peers. The author reflected that males building their water safety knowledge from peers is problematic since males are more likely to take part in high risk activities/behaviors (Moran, 2008b) and have poor knowledge of water safety (Moran, 2008a). Females however, were more likely to gain their beliefs towards water safety from their families and schools (Moran, 2009a, 2009b) who are likely to be stronger resources for safety practices and knowledge. Moran (2009a) also shows that socio-economic status was not observed as a factor in how children learn about water safety. These findings help in understanding how children and young adults formulate their understanding of water safety, and will help in identifying solutions to revise current water safety and drowning prevention education programming.

Stallman, Junge, and Blixt (2008) conducted a study to begin the development process of a model for teaching swimming, based on the causes of drowning. Researchers surveyed drowning reports, interviewed drowning survivors, and observed simulated episodes to determine common characteristics associated with drowning. The analysis showed four emerging themes among the simulated episodes and the survivor interviews: the victim didn't realize the danger; the victim suffered and unexpected occurrence such as their entry into the water; the victim suffered an expected result such as difficulty surfacing; and the victim's skills were inadequate for survival. Additionally, analyzed literature from 25 aquatic organizations' 
programming found that children taking swimming lessons or other forms of swim training are not adequately prepared in drowning prevention. Children also are not trained in how to cope with an unexpected submersion event. A "great variation" in content among the 25 aquatic programs analyzed was also noted by Stallman et al. (2008). This disconnection in content indicates that the goal of combating drowning by swimming education has not been achieved. Future recommendations call for using the known causes of drowning and translating this knowledge into what children should learn in swimming education (Stallman et al., 2008). This research points to both a lack of understanding associated to victim's risk, consistency issues in swimming education for the purpose of reducing drowning risks, and a lack of consensus on how to move forward. By developing the foundation in recognizing that the current structure and method for teaching children to swim does not correlate to a reduction in drowning risk is an important step.

\section{Parents and Water Safety}

Parents and caregivers are an important component of any drowning prevention and water safety solution. Constant supervision of children is an important safety procedure needed for safe enjoyment of recreational aquatics. The National Drowning Prevention Alliance (2009) released a position paper discussing layers of protection around water. The paper calls for (a) active parent supervision when water is present, even if no water activities are taking place, and (b) the need for constant and responsible supervision among parents, caregivers, and other adults in addition to the presence of lifeguards. Adults being within arm's reach of infants and toddlers in or around water (touch supervision), use of water-watcher tags, and choosing proper floatation devices were all recommended for parents. 
Moran and Stanley (2006) conducted a study in New Zealand to gage parents' reasoning for enrolling their child in swim lessons and their understanding of the purpose of swim lesson after the lessons program had ended using open ended questionnaires. During the child lessons, parents $(n=106)$ involved in the study were provided with resources on child water safety. Learning to swim was ranked highest both pre- and post-lessons (pre- 43.4\%, post- 41.9\%). While safety (pre- $34.9 \%$, post- $25.7 \%$ ) as a reason ranked much lower on the post lesson questionnaire, confidence in swimming (pre- $16.0 \%$, post- $23.8 \%$ ) ranked higher in the post lesson questionnaire, indicating that parents saw value in increasing their child's confidence in the water after reviewing the resources provided. Moran and Stanley (2006) suggest that water safety concepts be taught to parents at the same time as the children are in swimming lessons. The authors suggest that while their children are actively engaged in swimming lessons, a separate instructor discusses the importance of water safety and the different methods of infusing these concepts into what their children are learning in swimming lessons (Moran \& Stanley, 2006).

Morrongiello, Sandomierski, and Spence (2013) conducted a longitudinal study that gaged parent perceptions of a child's drowning risk after taking swim lessons. Parents who attended their child's swimming lessons and who identified themselves as being familiar with their child's swimming abilities $(n=387)$ completed researcher developed questionnaires. The study used an ANOVA to compare parent perceptions over the course of the study. Results showed that parents perception of their child's swimming ability had significantly increased $(\mathrm{p}<.001)$ after taking swim lessons. Additionally, it was found that parent's perceived swimming ability was enough to keep their child safe around the water $(\mathrm{p}<.001)$. The study also showed significant findings $(\mathrm{p}<.001)$ that parents have poor judgment of their child's actual swimming 
abilities and their ability to keep themselves safe around the water (Morrongiello et al., 2013).

This is a concept that swimming ability is enough to prevent drowning must be thoroughly disproven, so that parents, educators, and school administrators fully understand that understanding how swim is just one step towards drowning prevention.

\section{Current Recommendations in Instruction}

Limited reviews have taken place of current literature in the field of drowning prevention education. Yarger and Dalcher (2008) commented on the extent to which aquatic training agencies and programs are relying more on a video-driven approach to get information to students enrolled in programs, which in many ways reduces the role of the instructor to a facilitator. Yarger and Dalcher concluded that weakened aquatic educator preparation has resulted in the need for highly skilled educators and quality programming across all areas of the aquatics field (Yarger \& Dalcher, 2008). Yarger and Ogoreuc (2009) further stated that there are disparities in aquatic professional development and training among different aquatic related organizations. These training disparities result from a lack of consensus and training standards in the aquatic and drowning prevention fields.

Australia is looked upon as a leading country in water safety and drowning prevention by many countries around the world. Lynch (2012) discussed that in spite of the advanced programming and emphasis that has been placed on safer waters and safer swimming in the country of Australia in the past few decades, the drowning rate is on a plateau or on a slight increase every year. Despite developed education programs and what appears to be a welleducated public, drowning death levels are unchanged (Lynch, 2012). Researchers have identify that aquatic and drowning prevention researchers need to work together to form solutions (Stallman \& Kjendlie, 2013). Though there is limited literature in drowning prevention and 
aquatic education, relevant topics among future collaborations surface, which show the need for consensus building among experts.

In the WHO' 2014 GDR, 10 action steps were described to help reduce drowning on a global scale. The last of these action steps was related to future research, and highlighted the need to "address priority research questions with well-designed studies (World Health Organization, 2014).” Though research has been conducted surrounding the incidence of drowning, future research must address the outstanding questions to reduce the number of drownings on a global scale. Questions surrounding the correlation of swimming ability and drowning risk (Stallman et al., 2008), best practices of presenting drowning prevention education (Moran \& Stanley, 2006), and racial relations to drowning risk (Irwin et al., 2009a) still remain.

\section{Review of Literature: Issues in Drowning Prevention Education Research}

Issues exist in the United States (CDC, 2012) and across the world (WHO, 2014) in regards to well solidified methods of data collection and statistical analysis on drowning. On a wider spectrum, research surrounding: a) surveillance of drowning injuries and fatalities (WHO, 2014; CDC, 2012), b) child and parent comprehension of drowning risk (Morrongiello et al., 2013; Moran \& Stanley; 2006), and c) solid educational approaches to the instruction of drowning prevention (Stallman et al., 2008; Yager \& Dalcher, 2008) currently lacks a foundational bases on which future research can form theoretical solutions and improve drowning prevention education. Data collection and statistical analysis challenges are synthesized while the current state of drowning prevention is compared to the famous "chaos in the brick yard" analogy (Forscher, 1963) to depict the current state of challenges in drowning and drowning prevention education. Lastly, the Delphi method as a consensus building solution is analyzed for use in this current research. 


\section{Data Collection and Statistical Analysis Challenges}

In a 2012 report, the CDC investigated the current limits surrounding data collection for injury prevention. The report explained that there are a number of barriers that limit the collection and analysis of surveillance data in regard to injuries. The report looked specifically at childhood injury prevention as a whole. Addressing gaps in data collection, improving access to data, and improving analysis, interpretation and dissemination were addressed as goals for the future. The CDC has stated there are limits on their data collection abilities and access to this data presents a significant challenge to be overcome (CDC, 2012). Since surviving a drowning event can leave the injured person with a number of neurological and physical disabilities, understanding the true scope of the drowning problem is a fundamental component to forming a solution. There are a known number of fatal drowning deaths on an annual basis; however solid data surrounding the number of non-fatal drownings that received hospital related care is still unknown, even though some studies have attempted to quantify this data. For example, a CDC study reported by the National Center for Injury Prevention and Control reported that 4,174 persons on average were treated in United States Emergency Departments for nonfatal drownings, in addition to the 3,372 deaths in 2001 (Gilchrist, Gotsch, \& Ryan, 2004). More recently, a 2012 report from the state of Florida revealed that while 440 deaths were reported an additional 343 hospitalizations for non-fatal drownings were reported (Florida, 2012).

Estimates of fatal to non-fatal drowning comparisons vary, and have been reported as 2-4 times higher than fatal drowning rates by Suominen and Vahatalo (2012), 1 death per 13 survivors of a drowning death by Layon and Modell (2009), near drowning 20-50 times the rate of fatal drowning Onyekwelu (2009), 1-4 hospitalization for non-fatal drowning for every fatal drowning (Brenner, 2003), and for every child that fatally drowns 4 are hospitalized and 16 
receive emergency department care Moon and Long (2002) (as cited in Clemens, 2014). While each of these studies attempts to quantify this comparison, few actually reported fatal drowning rates for the sample's data collection area, gave definitions of terms, and lacked long term follow up or post analysis to verify the results (Clemens, 2014). While all of these reports show a much larger drowning problem in comparison to only considering fatality numbers, there is a wide disparity among these reports and solidified numbers of non-fatal drownings each year are rarely reported.

Since there are wide disparities in the studies being reported, the results can easily be misinterpreted and misrepresented in a number of ways. An example of this is a case-control research study conducted by Brenner et al. (2009) which suggests that formal swimming lessons can reduce the risk of drowning by $88 \%$ in children ages $1-4$. Data was collected through medical examiner reports and through interviews with family members of drowning victims. Out of 264 identified cases, 61 in the 1-4 age categories were interviewed or surveyed, and 27 in the 5-19 age group were interviewed or surveyed. The same study found no significant association between formal swimming lessons and drowning risk of older age ranges, and between informal swimming lessons and drowning risk in any age range. Though this can be constructed as a solution for one age range (1-4 years old), the research had a small sample size and identified that bias cannot be ruled out in the interview segment of the data collection (Brenner et al., 2009). Even though this study points to significant reduction in drowning risk, it is only for one particular age group and clearly explains the likelihood of biased results, some organizations have used this statistic as a marketing tool for swim lessons for all age ranges.

\section{Chaos in the Brickyard}


Forscher (1963) wrote a letter to the editor of Science examining scientific research consensus in relation to brick makers and construction. In Forscher's letter he described "brick makers," and the goal of the "brick makers," was to build an "edifice," out of the "bricks," they constructed. The brick maker's (researcher's) goal is to bring together well made individual bricks (facts or research studies) and build a strong edifice (consensus/problem solving strategies) that are both helpful and useful to the users. While in contradiction to this goal, faulty bricks and poorly constructed edifices would be dangerous to all users. Forscher's concept of "chaos in the brick yard," is derived from the idea of by having faultily constructed bricks (research studies) or too many poorly made bricks, a strong edifice could never be constructed. Through the concept of "chaos," in Forcher's analogy, points to poorly constructed and executed research studies which do not build off of previous research. Theoretically, when too many poorly made bricks are constructed an edifice (solution) is never formed since a strong foundation cannot be achieved in which to build upon.

In relation to the research surrounding drowning prevention education, important relatable characteristics exist that allow a comparison of the current research body to the "chaos in the brickyard" analogy. Though research does exist in drowning prevention education, researcher cannot seem to find consensus to formulate solutions to bring drowning prevention education research towards a well-constructed "edifice." The research studies in drowning prevention (bricks) are well formed, but together; do not form an "edifice" to build solutions. However, a clear construction plan for constructing the "edifice," to solve the outstanding problems does not seem to exist. As the WHO's GDR recommendations point out there is a need to “...address priority research questions with well-designed studies (WHO, 2014)," researchers must determine, through consensus, what our "construction plan," is and build a strong 
foundation of well made "bricks." This research will support in constructing a plan to form a stronger foundation for future research. Through brainstorming and consensus building among drowning prevention education experts, a list of important and empirical research questions will emerge to lay the ground work for future research, in the hopes of building a strong foundation to construct a strong and sturdy edifice (solutions).

\section{Delphi Method in Consensus Building}

Attempts to formulate a high priority research agenda have taken many forms. As part of the research process, researchers are often making assertions to future research endeavors; more commonly known as the "next step." Chen (2013) and Pate et al. (2013) authored articles surrounding the next steps or top research questions in children's physical activity grounded in the literature to guide future practice. Both Chen (2013) and Pate et al. (2013) use a thorough literature review as the foundation to summarize outstanding research questions. However, two flaws exist in this practice: (a) being able to bracket the researcher's own opinions and (b) little to no validation if these outstanding research questions are truly top priorities in the field. The approach of only review literature as a means for this objective has a large amount of subjectivity and cannot be relied upon to provide a strong foundational base to provide future research directions in any field. Research-based methods for completing this process do exist. Round tables and focus groups, stake holder surveys and questionnaires, Delhi methods, and public input sessions have been used in previous research based attempts (Bryant, Sanson-Fisher, Walsh, \& Stewart, 2014). The Delphi method is unique in a number of ways when it comes to consensus building among research agendas that potentially impact a large field.

The Delphi method is a consensus building and forecasting technique that has been used across a number of different fields such as nursing research (de Mello Perieira \& Titonelli 
Alvim, 2015), construction management research (Sourani \& Sohail, 2015), health science research (Wong et al., 2014), and across many other fields of study for a variety of applications. A Delphi method uses the anonymous judgement and opinions of experts in a particular field to explore new concepts and build consensus in and out of information systems body of knowledge (Skulmoski, Hartman, \& Krahn, 2007). Delphi studies use multiple rounds of surveying experts to form decisions, consensus, and forecasts through feedback processes and idea sharing. A large amount of flexibility exists in the methodological planning and formation of a Delphi study. One of the largest strengths of a Delphi method is the anonymity of the experts which allows free expression of their opinions regardless of social and political pressures (Skulmoski et al., 2007). This allows for the decisions to be evaluated on their merit versus who proposed the initial idea. Additionally, participants are also able to change their views in each round to reflect on group consensus by agreeing or dissenting from the group (Skulmoski et al., 2007).

When attempting to determine future research agendas for a under researched and chaotic scholarly area such as drowning prevention education, a Delphi method appears reasonable fit for a number of reasons when compared to other methodological options. The Delphi study will (a) allow for complete anonymity of the participants, (b) provide the opportunity for participants to change their views and opinions during data collection, (c) allow for a more in-depth analysis of the results of the study, and (d) allow for follow up and validation studies to be completed (Skulmoski et al., 2007). While other research methodologies such as surveys can provide anonymity of the participants and follow up/validation, they rarely allow for participants to modify their views after reviewing others responses and do not allow for an analysis of the modification process in comparison to the final results. 
Yager et al. (2014) used a survey method to develop an understanding of expert opinion to aid in the development of future practice guidelines for the American Psychiatric Association. Though the report does not explicitly state weaknesses in the data collection process or the methodological choice, the goal of the study was to use expert opinion to inform future practice guidelines for an entire field. By extending on the survey used, it could be argued that a Delphi study would have been more appropriate to better form consensus among experts in Yager et al. (2014). The study was attempting to use a large number of experts found through a snowballing procedure $(n=784)$. Though there is no reported maximum size of a sample in a Delphi study, it could be argued that Yager et al. (2014) would be too large for a Delphi method. However, future research using the same goals should consider the increased benefits and usefulness of a Delphi method.

While a Delphi method does come with a number of strengths, there are also inherent weaknesses in the methodology. The root purpose of a Delphi method is often influenced by the personal opinions, beliefs, and bias of the principle researcher. The principle research in most cases will hold strong beliefs surrounding the purpose and outcome of the study. It is important that the researcher have the ability to bracket their beliefs and remain a neutral and facilitating role to ensure this doesn't affect the outcome of the study. Additionally, current literature surrounding the Delphi method remarks that this methodology be well planned and executed as a fault and flaw of many Delphi studies point to poor planning and sloppy execution (Skulmoski, Hartman, \& Krahn, 2007).

Similarly to this proposed study, Katcher et al. (2006) used experts in the field injury prevention to develop consensus to identify and rate home injury hazards for children. Experts were identified by a set list of criteria and verification of each expert's qualifications were 
verified prior to the invitation to participate in the study was sent out. Round one of Katcher et al. (2006) employed a brainstorming round in which experts gave their individual opinion and submitted 5-7 injury hazards they felt were present in the home. Round two consisted of the study asked the experts to rate these items on a five point Likert scale of importance (Katcher et al., 2006). This is the same Delphi methodology that this proposed study will follow, plus an additional validation component. In a review of the Delphi method's strengths and weaknesses Kennedy (2004) proposed that a weakness of most Delphi studies involved a lack of validation. Kennedy put forward recommendations that Delphi study results could be validated using qualitative methods such as ethnography or interviews to provide validity and reliability to the results of consensus building (Kennedy, 2004). This proposed study will also include follow up interviews with randomly selected participants to enhance the validity and reliability of the results.

\section{Conclusion}

"It became difficult to find a suitable plot for construction of an edifice because the ground was covered with loose bricks. It became difficult to complete a useful edifice because, as soon as the foundations were discernible, they were buried under an avalanche of random bricks. (Forscher 1963)"

Forscher's (1963) analogy of the bricks to research, brick makers to researchers, and edifices to blueprints/theories has strong relations to the current state of drowning prevention education research. In reviewing literature surrounding injury surveillance on drowning, drowning prevention education research, and the issues surrounding drowning/drowning prevention education research overarching themes appear: a) research in all three areas has been conducted; b) a foundational understanding that drowning is a problem exists; c) education is 
recognized as a key prevention strategy; and d) limited solutions or theories have surfaced. Ellen et al. (2014) completed a qualitative interview based study to determine what views exist surrounding the "next steps," in implementing supports for decision making in health systems. Ellen et al.'s purpose was to first determined the barriers present and then on a large scale $(n=57)$ analyze the views of the population. In relation to drowning prevention education, the barriers have been determined on a number of fronts: a) drowning fatalities and non-fatal injuries are still occurring despite current educational endeavors (CDC, 2013); b) high risk populations have been identified (Irwin et al., 2009a, 2009b; Myers, n.d., para 4); c) parents and children do not fully comprehend the risk of drowning (Morrongiello et al., 2013; Moran \& Stanley; 2006); d) variations exist in educational approaches (Stallman at al., 2008); e) educator preparation flaws exist (Yarger \& Dalcher, 2008); and f) lack of coordination among experts and researchers also is present (Lynch, 2012). These known barriers could be looked upon as what Forscher (1963) referred to as his famous "chaos in the brickyard" analogy, yet a "next step" must now be determined. Experts in both practice and scholarship can formulate a "blueprint" (consensus) to determine what outstanding research questions and topics must be addressed to form solutions on drowning prevention education. This "blueprint," will be a means to strengthen future research and educational endeavors. 


\section{References}

Beale, A., \& Lynn, S. (2011). Swimming in new waters: Profiling K-12 aquatic physical activity in Florida as a viable lifesaving force in physical education. International Journal of Aquatic Research and Education, 5(4), 402-420.

Blackwood, B., Albarran, J. W., \& Latour, J. M. (2011). Research priorities of adult intensive care nurses in 20 European countries: a Delphi study. Journal of Advanced Nursing, 67(3), 550-562. doi:10.1111/j.1365-2648.2010.05512.x

Blitivich, J. D., Moran, K., Petrass, L. A., McElroy, G. K., \& Stanley, T. (2012). Swim instructor beliefs about toddler and preschool swimming and water safety education. International Journal of Aquatic Research and Education, 6(2), 110-121.

Brenner, R. A., Taneja, G. S., Haynie, D. L., Trumble, A. C., Qian, C., Kliner, R. M., \& Klebanoff, M. A. (2009). Association between swimming lessons and drowning in childhood. Archives of Pediatric \& Adolescent Medicine, 163(3), 203-210. doi: 10.1001/archpediatrics.2008.563.

Bryant, J., Sanson-Fisher, R., Walsh, J., \& Stewart, J. (2014). Health research priority setting in selected high income countries: a narrative review of methods used and recommendations for future practice. Cost Effectiveness \& Resource Allocation, 12(1), 23-42. doi:10.1186/1478-7547-12-23

Bulger, S. M. \& Housner, L. D. (2007). Modified Delphi investigation of exercise science in physical education teacher education. Journal of Teaching in Physical Education, 26, 5780. 
Cardorn, G., Verstraete, S., \& De Clercq, D. (2004). Physical activity levels in elementaryschool physical education: A comparison of swimming and nonswimming classes. Journal of Teaching In Physical Education, 23(3), 252-263

Center for Disease Control and Prevention. (2012). National Action Plan for child injury prevention. Retrieved from http://www.cdc.gov/safechild/pdf/National_Action_Plan_for_Child_Injury_Prevention.p df

Centers for Disease Control and Prevention. Web-based Injury Statistics Query and Reporting System (WISQARS) [Online]. (2013). National Center for Injury Prevention and Control, Centers for Disease Control and Prevention (producer). Available from: URL: www.cdc.gov/ncipc/wisqars. [2015/3/30].

Centers for Disease Control and Prevention. (2014). Unintentional drowning: Get the facts. Retrieve from: http://www.cdc.gov/HomeandRecreationalSafety/WaterSafety/waterinjuries-factsheet.html

Chen, A. (2013). Top 10 research questions related to children physical activity motivation. Research Quarterly for Sport and Exercise, 84(4), 441-447. doi: $10.1080 / 02701367.2013 .844030$

Clemens, T. (2014). Proceedings from the World Conference on Drowning: Non-fatal drowning: A review of epidemiology, pathophysiology, treatment and prevention. Potsdam, Germany.

de Mello Pereira, R. D., \& Titonelli Alvim, N. A. (2015). Delphi technique in dialogue with nurses on acupuncture as a proposed nursing intervention. Anna Nery School Journal Of 
Nursing / Escola Anna Nery Revista De Enfermagem, 19(1), 174-180. doi:10.5935/14148145.20150024

Drowning--United States, 2005-2009. (2012). MMWR. Morbidity and Mortality Weekly Report, 61(19), 344-347.

Ellen, M. E., Léon, G., Bouchard, G., Ouimet, M., Grimshaw, J. M., \& Lavis, J. N. (2014). Barriers, facilitators and views about next steps to implementing supports for evidenceinformed decision-making in health systems: a qualitative study. Implementation Science, 9(1), 14-39. doi:10.1186/s13012-014-0179-8

Falzarano, M., \& Genevieve, P. Z. (2013). Seeking consensus through the use of the Delphi technique in health science research. Journal of Allied Health, 42(2), 99-105.

Fink, A., Kosecoff, J., Chassin, M., \& Brook, R. H. (1984). Consensus methods: Characteristics and guidelines for use. American Journal of Public Health, 74(9), 979-983.

Florida Department of Health. (2012). Flordia Injury Facts - Drowning Surveillance Data: 2012. Retrieved from http://www.floridahealth.gov/statistics-and-data/florida-injurysurveillance-system/_documents/data-fact-sheets/drowning-2012.pdf

Forscher, B. K. (1963). Chaos in the brickyard [Letter to the editor]. Science, 142, 339.

Fralick, M., Gallinger, Z. R., \& Hwang, S. W. (2013). Differences in drowning rates between rural and non-rural residents of Ontario, Canada. International Journal of Aquatic Research and Education, 7(4), 332-343.

Gilchrist, J., Gotsch, K., \& Ryan, G. (2004). Nonfatal and fatal drownings in recreational water settings: United States, 2001-2002. Morbidity and Mortality Weekly Report, 53(21), 447452. 
Golden, F. St C., Tipton, M. J., \& Scott, R. C. (1997). Immersion, near-drowning and drowning, British Journal of Anesthesia, 79, 214-225.

Golob, M. I., Giles, A. R., \& Rich, K. M. (2013). Enhancing the relevance and effectiveness of water safety education for ethnic and racial minorities. International Journal of Aquatic Research and Education, 7(1), 39-55.

Grosse, S. J. (2014). Aquatic safety for individuals with autism spectrum disorders. International Journal of Aquatic Research and Education, 8, 295-301. doi: 10.1123/ijare.2014-0043

Hsu, C. C., \& Sandford, B. A. (2007). The Delphi technique: Making sense of consensus. Practical Assessment, Research \& Evaluation, 12(10), 1-8.

International Life Saving Federation (ILSF). (2007). Position statement: Swimming and water safety education. International Journal of Aquatic Research and Education, 1(3), 373377.

Irwin, C. C., Irwin, R. L., Ryan, T. D., \& Drayer, J. (2009a). The mythology of swimming: Are myths impacting minority youth participation? International Journal of Aquatic Research and Education, 3(1), 10-23.

Irwin, C. C., Irwin, R. L., Ryan, T. D., \& Drayer, J. (2009b). Urban minority youth swimming (in)ability in the United States and associated demographic characteristics: Towards and drowning prevention plan. Injury Prevention, 15(4), 234-239.

Katcher, M. L., Meister, A. N., Sorkness, C. A., Staresinic, A. G., Pierce, S. E., Goodman, B. M., \& ... Schirmer, J. A. (2006). Use of the modified Delphi technique to identify and rate home injury hazard risks and prevention methods for young children. Injury Prevention, 12(3), 189-194. doi:10.1136/ip.2005.010504 
Keeney, S., Hasson, F., \& McKenna, H. (2011). The Delphi technique in nursing and health research. West Sussex, U.K.: Blackwell.

Kennedy, H. (2004). Enhancing Delphi research: methods and results. Journal Of Advanced Nursing, 45(5), 504-511. doi:10.1046/j.1365-2648.2003.02933.x

Langendorfer, S. J. (2011). Considering drowning, drowning prevention, and learn to swim, International Journal of Aquatic Research and Education, 5, 236-243.

Lifesaving Society of Canada. (2010). Study reveals new Canadians at higher risk for drowning [Press release]. Retrieved from http://www.lifesaving.ca/index.php/study-reveals-newcanadians-higher-risk-drowning/

Lynch, T. J. (2012). Swimming and water safety: Reaching all children in Australian primary schools. Can you swim? An exploration of measuring real and perceived water competency. International Journal of Aquatic Research and Education, 6(2), 267-278.

Martin, N. T., \& Witman, D. (2010). Factors affection minority drowning. International Journal of Aquatic Research and Education, 4(1), 9-18.

Mills, J., Bonner, A., \& Francis, K. (2006). The development of constructivist grounded theory. International Journal of Qualitative Methods, 5(1), 1-10.

Moran, K., Stallman, R. K., Kjendlie, P., Dahl, D., Blitvich, J. D., Petrass, L. A., McElroy, G. K., Goya, T., Teramoto, K., Matsui, A., \& Shimongata, S. (2012). Can you swim? An exploration of measuring real and perceived water competency. International Journal of Aquatic Research and Education, 6(2), 122-135.

Moran, K. (2008a). Will they sink or swim? New Zealand youth water safety knowledge and skills. International Journal of Aquatic Research and Education, 2(2), 114-127. 
Moran, K. (2008b). Youth aquatic recreation: The pleasures and pitfalls of an aquatic lifestyle in New Zealand. In N.P. Beaulieu (Ed.), Physical activity and children: New research (pp. 35-63). Hauppauge, NY: Nova Science Publishers.

Moran, K. (2009a). Parent/caregiver perception and practice of child water safety at the beach. International Journal of Injury Control and Safety Promotion, 16(4), 215-221. doi: $10.1080 / 17457300903307045$

Moran, K. (2009b). Parents, pals, or pedagogues? How youth learn about water safety. International Journal of Aquatic Research and Education, 3(2), 121-134.

Moran, K. (2010). Risk of drowning: The "iceberg phenomenon" revisited. International Journal of Aquatic Research and Education, 4(2), 115-126.

Moran, K., \& Stanley T. (2006). Toddler drowning prevention: Teaching parents about water safety in conjunction with their child's in-water lessons. International Journal of Injury Control and Safety Promotion, 13(4), 254-256.

Morrongiello, B.A, Sandomierski, M., \& Spence, J. R. (2013). Changes over swim lessons in parents' perceptions of children's supervision needs in drowning risk situations: "His swimming has improved so now he can keep himself safe.” Health Psychology 32(9), 18. doi: $10.1037 / \mathrm{a} 0033881$

Murphy, S. L., Xu, J., \& Kochanek, K. D. (2013). Deaths: Final data for 2010. National Vital Statistics Report, 61 (4), 1-118.

Myers, S. (n.d.). Review of mortality in autism drowning. Association for Science in Autism Treatment. Retrieved from http://www.asatonline.org/researchtreatment/resources/topical-articles/review-of-mortality-in-autism-drowning/ 
National Drowning Prevention Alliance, Education Committee. (2009). Layers of protection around aquatic environments to prevent child drowning. Retrieved from http://www.floridahealth.gov/programs-and-services/prevention/drowningprevention/_documents/ndpa-position-paper.pdf

Pate, R. R., O’Neill, J. R., Brown, W. H., McIver, K. L., Howie, E. K., \& Dowda, M. (2013). Top 10 research questions related to physical activity in preschool children. Research Quarterly for Sport and Exercise, 84(4), 448-455. doi: 10.1080/02701367.2013.844038

Pia, F. (1974). Observations on the drowning of non-swimmers. The Journal of Physical Education, 71(6), 164-167.

Pia, F. (1984). The RID factor as a cause of drowning. Parks and Recreation.

Plüddemann, A., Heneghan, C., Thompson, M., Roberts, N., Summerton, N., Linden-Phillips, L., ... Price, C.P. (2010). Prioritisation criteria for the selection of new diagnostic technologies for evaluation. BCM Health Services Research, (5). doi: 10.1186/14726963-10-109

Ramos, W., Beale, A., Chamber, P., Dalke, S., Fielding, R., Kublick, L, .. Wernicki, P. (2015). Primary and secondary drowning interventions: The American Red Cross circle of drowning prevention and chain of drowning survival, International Journal of Aquatic Research and Education, 9, 89-101. doi: 10.1123/ijare.2014-0045

Sandrey, M. A., \& Bulger, S. M. (2008). The Delphi method: An approach for facilitating evidence based practice in athletic training. Athletic Training Education Journal, 3(4), $135-142$. 
Sato, T., \& Hodge, S.R. (2012). Exploring the meaning African American PETE teacher candidates ascribe to their aquatic experiences. The Journal of Negro Education, 81(4), $379-391$.

Sbarbaro, V. S., \& Enyeart Smith, T. M. (2011). An analysis of water safety behaviors among migrant and economically/educationally disadvantage middle school students. The Health Educator, 43(1), 21-28.

Skulmoski, G. J., Hartman, F. T., \& Krahn, J. (2007). The Delphi method for graduate research. Journal of Information Technology Education, 6, 1-21.

Sourani, A., \& Sohail, M. (2015). The Delphi method: review and use in construction management research. International Journal of Construction Education \& Research, 11(1), 54-76. doi:10.1080/15578771.2014.917132

Stallman, R. K., \& Kjendlie, P. (2013). “We're in the same boat - brother!” Aquatic movement research and drowning prevention research. International Journal of Aquatic Research and Education, 7(1), 102-104.

Stallman, R. K., Junge, M., \& Blixt, T. (2008). The teaching of swimming based on a model derived from the cause of drowning. International Journal of Aquatic Research and Education, 2(4), 372-382.

Vagias, Wade M. (2006). Likert-type scale response anchors. Clemson International Institute for Tourism \& Research Development, Department of Parks, Recreation and Tourism Management. Clemson University.

Vittone, M. \& Pia, F. A. (2006). "It doesn't look like they're drowning” how to recognize the instinctive drowning response, On Scene, Fall 2006, 14. 
Wong, S. T., Browne, A. J., Varcoe, C., Lavoie, J., Fridkin, A., Smye, V., \& ... Tu, D. (2014). Development of health equity indicators in primary health care organizations using a modified Delphi. Plos ONE, 9(12), 1-15. doi:10.1371/journal.pone.0114563

World Congress on Drowning. (2002). Violence and injury prevention: Drowning. Retrieved from http://www.who.int/violence_injury_prevention/other_injury/drowning/en/

World Health Organization. (2014). Global Drowning Report. Retrieved from http://apps.who.int/iris/bitstream/10665/143893/1/9789241564786_eng.pdf?ua=1\&ua=1

Yager, J., Kunkle, R., Fochtmann, L., Reid, S., Plovnick, R., Nininger, J., \& ... Vergare, M. (2014). Who's Your Expert? Use of an Expert Opinion Survey to Inform Development of American Psychiatric Association Practice Guidelines. Academic Psychiatry: The Journal Of The American Association Of Directors Of Psychiatric Residency Training And The Association For Academic Psychiatry.

Yarger, L., \& Ogoreuc, R. E., (2009). Aquatic professional development. International Journal of Aquatic Research and Education, 3(1), 83-88.

Yarger, L., \& Dalcher S. P. (2008). The instructor's role in aquatic education: Some personal observations. International Journal of Aquatic Research and Education, 2(3), 266-269.

Yang, L., Nong, Q.M., Li, C., Feng, Q.M., Lo, \& S.K. (2007). Risk factors for childhood drowning in rural regions of a developing country; A case-control study. Injury Prevention, 13(3), 178-182. doi: 10.1136/ip.2006.013409 
Table 9

Extensive Literature Review - Potential Important Research Questions in Drowning

\begin{tabular}{|c|c|c|}
\hline Topic & Question & Supporting Literature \\
\hline Drowning Data & $\begin{array}{l}\text { What are the current flaws in US injury } \\
\text { surveillance data collection and what steps } \\
\text { can be taken to provide more accurate data? }\end{array}$ & $\begin{array}{l}\text { (Center for Disease } \\
\text { Control and } \\
\text { Prevention, 2012) }\end{array}$ \\
\hline Drowning Data & $\begin{array}{l}\text { Can a more accurate depiction of the fatal to } \\
\text { non-fatal injury ratio for drowning be } \\
\text { formed? }\end{array}$ & (Clemens, 2014). \\
\hline Drowning Data & $\begin{array}{l}\text { Can a more thorough understanding of the } \\
\text { relation to swimming skill and drowning risk } \\
\text { be determined? }\end{array}$ & (Brenner et al., 2009) \\
\hline High Risk & What education methods or approaches can & (Sbarbaro \&Enyeart \\
\hline Populations & $\begin{array}{l}\text { be used to lessen the drowning risk of } \\
\text { immigrant and minority communities? }\end{array}$ & $\begin{array}{l}\text { Smith, 2011; } \\
\text { Lifesaving Society of } \\
\text { Canada, 2010) }\end{array}$ \\
\hline $\begin{array}{l}\text { High Risk } \\
\text { Populations }\end{array}$ & $\begin{array}{l}\text { What education methods or approaches can } \\
\text { be used to lessen the drowning risk of } \\
\text { individuals with disabilities? }\end{array}$ & $\begin{array}{l}\text { (Grosse, 2014; Myers, } \\
\text { n.d., para 4). }\end{array}$ \\
\hline $\begin{array}{l}\text { Water Safety } \\
\text { Instruction }\end{array}$ & $\begin{array}{l}\text { What teacher education training } \\
\text { modifications must be made to place a higher } \\
\text { emphasis on drowning prevention education? }\end{array}$ & $\begin{array}{l}\text { (Blitvich, Moran, } \\
\text { Petrass, McElroy, and } \\
\text { Stanley, 2012; Lynch, } \\
\text { 2012) }\end{array}$ \\
\hline $\begin{array}{l}\text { Water Safety } \\
\text { Instruction }\end{array}$ & $\begin{array}{l}\text { What barriers exist for teaching drowning } \\
\text { prevention education in school curriculums? }\end{array}$ & (Beale \& Lynn, 2011) \\
\hline $\begin{array}{l}\text { Children and Water } \\
\text { Safety }\end{array}$ & $\begin{array}{l}\text { What educational methods or approaches can } \\
\text { be employed to reduce male risk taking } \\
\text { behavior in water? }\end{array}$ & $\begin{array}{l}\text { (Moran, 2008a } \\
\& 2008 \mathrm{~b})\end{array}$ \\
\hline $\begin{array}{l}\text { Parents and Water } \\
\text { Safety }\end{array}$ & $\begin{array}{l}\text { What steps can be taken to increase } \\
\text { parent/caregiver knowledge of risks and } \\
\text { prevention strategies? }\end{array}$ & $\begin{array}{l}\text { (Morrongiello, } \\
\text { Sandomierski, \& } \\
\text { Spence, 2013; Moran } \\
\text { \& Stanley, 2006). }\end{array}$ \\
\hline
\end{tabular}




\title{
Appendix B
}

\author{
IRB Exemption Notice
}

\section{W. WestVurginiaUniversity. \\ Office of Research Integrity and Compliance

\author{
886 CHESNUT RIDGE ROAD MORGANTOWN, WV 25606
} \\ Acknowledgement Letter Exempt Initial Protocol Review}

$\begin{array}{ll}\text { Action Date } & 01 / 08 / 2016 \\ \text { To } & \text { Andrea Taliaferro } \\ \text { From } & \text { WVU Office of Research Integrity and Compliance } \\ \text { Approval Date } & 01 / 08 / 2016 \\ \text { Expiration Date } & 01 / 07 / 2019 \\ \text { Subject } & \text { Acknowledgement Letter Exempt Initial Protocol Review } \\ \text { Protocol Number } & 1511924170 \\ \text { Title } & \text { A Delphi on Drowning Prevention Education Research }\end{array}$

The above-referenced study was reviewed by the West Virginia University Institutional Review Board IRB and was granted exemption in accordance with 45 CFR 46.101.

- This research study was granted an exemption because the Research involves educational tests, survey procedures, interview procedures or observation of public behavior and (i) information obtained is recorded in such a manner that human subjects cannot be identified, directly or through identifiers linked to the subjects; and (ii) any disclosure of the human subjects responses outside the research could not reasonably place the subjects at risk of criminal or civil liability or be damaging to the subjects financial standing, employability, or reputation [45 CFR 46.101(2)]. All exemptions are only good for three years. If this research extends more than three years beyond the approved date, then the researcher will have to request another exemption. The following documents have been acknowledged for use in this study and are available in the WVU+kc system:

Documents reviewed and/or approved as part of this submission:

Cover letter.1.5.docx: 2016-01-05-05:00

email round II.11.17.docx: 2015-11-29-05:00

email round III.11.17.docx: 2015-11-29-05:00

Final.Prop Survey.pdf: 2015-11-29-05:00 


\section{Appendix C}

\section{Cover Letter to Participants}

Dear Drowning Prevention Education Research Delphi Panel Member,

This letter is an invitation of your participation in a Delphi study to identify outstanding research questions related to drowning prevention education in the United States. The project is being conducted by Mr. Adam Katchmarchi (doctoral student) and Dr. Andrea Taliaferro (Assistant Professor) in the College of Physical Activity and Sport Sciences at West Virginia University. You were selected for participation in this study because you met three or more of the established criteria identifying you as an expert in this field: cited as a principle investigator or co-investigator on a minimum of 2 research studies; published at least 2 peer reviewed/refereed articles; developed or co-developed a drowning prevention or water safety education program or curriculum; published a minimum of 2 issues or practitioner based articles; compiled at least 10 years teaching drowning prevention or aquatic education; held employment in the field of drowning prevention and water safety education for a minimum of 5 years; worked with or directly for a national drowning prevention or water safety organization for at least three years; completion of an instructor or trainer certification in water safety or drowning prevention from a recognized organization. It is anticipated that up to 40 individuals will participate.

Participation in this project will involve three rounds of survey completion. Total participation should not exceed 1 hour. Responses from the exercise will be used to assist in the development of a comprehensive list of outstanding research questions relating to drowning prevention education in the United States. You may access the online survey by going to the following link: http://wvu.qualtrics.com/SE/?SID=SV_6RL2Gz8BHJaxwYB

Your involvement in this project will be kept as confidential as legally possible. All data will be reported in aggregate and no specific responses will be attributed to individual panel members so you can be assured of complete confidentiality regarding your personal opinions. There are no risks to being in this study other than minor discomfort from taking the time to participate. Your participation in this research study is completely voluntary. If at any time you wish to quit the survey, you may do so and you do not have to complete all the questions if you choose not to. There is no penalty for non-participation or early study withdrawal. West Virginia University IRB has acknowledged this protocol.

I sincerely hope that you take the time to complete this survey as your knowledge and feedback will significantly contribute to the creation of a comprehensive list of outstanding research questions related to drowning prevention education. Thank you very much for your time. Should you have any questions about this letter or the research project feel free to contact Andrea Taliaferro directly by phone at (304) 293-0852 or by email at andrea.taliaferro@ mail.wvu.edu. The West Virginia University Institutional Review Board (IRB) has acknowledgment of this study on file.

Again, thank you for your time and contribution to the completion of this project. Sincerely,

Adam Katchmarchi, M.S. Andrea Taliaferro, Ph.D. 


\section{Appendix D}

\section{Consensus Building Round 2 Invitation}

\section{Dear Participant,}

We recently contacted you about participating in a research study to identify outstanding research questions related to drowning prevention education in the United States. Thank you again for agreeing to serve as an expert panel member for that process. Your contribution and expertise are greatly appreciated!

We invite you to complete a second online survey where you will be prompted to rate a set of previously brainstormed outstanding research questions relating to drowning prevention education. Your participation in this phase of the research project will take approximately 20 minutes. West Virginia University IRB has acknowledged this protocol.

You do not have to answer all of the questions, and you can quit at any time. Participation in the study is voluntary and your responses will be kept confidential. There is no penalty if you choose not to participate in the research study. Your contact information will not be shared for any purpose outside of this study.

The survey will be available for 2 weeks after today; we ask that you please complete it no later than You need not complete the survey in one sitting. In order to complete the survey, please click on the following link:

Click here to take the Delphi Study Round 2 survey

Or copy and paste the following link into your browser:

I hope that you will participate in this research project, as it could be beneficial in identifying the importance of outstanding research questions relating to drowning prevention education. Thank you very much for your time. Should you have any questions about this letter or the research project, please feel free to contact Andrea Taliaferro at (304) 293-0852 or by e-mail at andrea.taliaferro@mail.wvu.edu.

Sincerely, Adam Katchmarchi, M.S. Andrea Taliaferro, Ph.D. West Virginia University College of Physical Activity and Sport Sciences 


\section{Appendix E}

\section{Consensus Building Round 3 Invitation}

\section{Dear Participant,}

Thank you again for your participation in a research study to identify outstanding research questions related to drowning prevention education in the United States. Your contribution and expertise are greatly appreciated!

A summary of the previously sorted results is attached here for your review. We invite you to complete the final (third) round of an online survey where you will be prompted to rate a final set of competencies related to outstanding research questions related to drowning prevention education. Your participation in this phase of the research project will take approximately 20 minutes. West Virginia University IRB has acknowledged this protocol.

You do not have to answer all of the questions, and you can quit at any time. Participation in the study is voluntary and your responses will be kept confidential. There is no penalty if you choose not to participate in the research study. Your contact information will not be shared for any purpose outside of this study.

The survey will be available for 2 weeks after today; we ask that you please complete it no later than You need not complete the survey in one sitting. In order to complete the survey, please click on the following link:

I hope that you will participate in this research project, as it could be beneficial in identifying the importance of outstanding research questions relating to drowning prevention education. Thank you very much for your time. Should you have any questions about this letter or the research project, please feel free to contact Andrea Taliaferro at (304) 293-0852 or by e-mail at andrea.taliaferro@mail.wvu.edu.

Sincerely, Adam Katchmarchi, M.S. Andrea Taliaferro, Ph.D. West Virginia University College of Physical Activity and Sport Sciences 


\section{Appendix F}

\section{Round 1 Survey}

Demographic Questionnaire

Please enter your email address:

What is your age range:
18-25 years old
26-35 years old
( $36-45$ years old
46-55 years old
56-65 years old
66 year old or older

What is your gender:
Male
Female
No response

Please select all of the following that describe your experience in drowning prevention education:

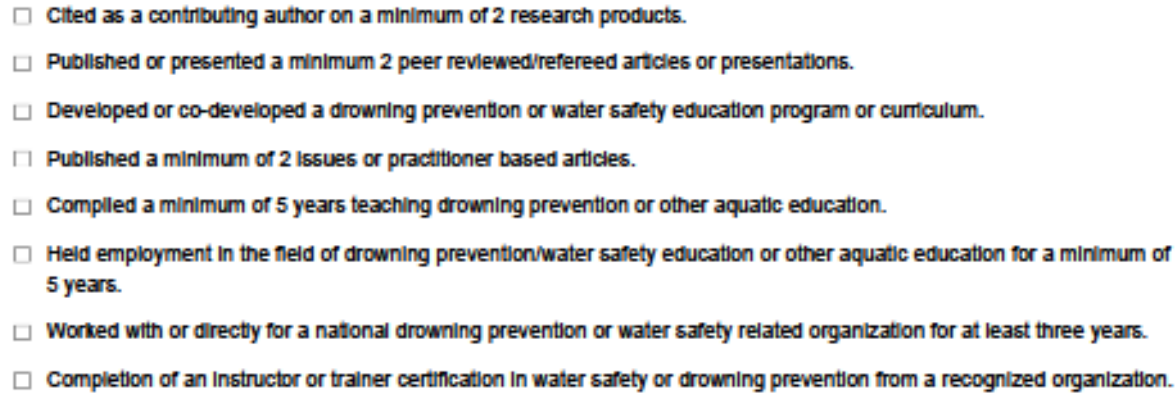




\section{Research Question Brainstorm}

In the following text boxes, please submit up to 5 questions you feel need to be addressed through research in drowning prevention and water safety education, with the goal of reducing drowning deaths in the United States. You are encouraged to write these in question form, however if you are unable to form a question, simply write the topic or issues you feel needs addressed through research.

Question 1

Question 2

Question 3

Question 4

Question 5 


\section{Appendix G}

\section{Brainstorming Results}

1. Why do we spend so much time talking about children drowning when over $60 \%$ of drowninga are adults?

2. What is the best way to reach the parents and community with a message

3. How can drowning prevention education go beyond children to an age range of teen through 35 ?

4. What evidence shows drowning incidents are reduced through swim lessons?

5. root cause of the incident

6. Parent education on water safey for preschool children

7. Should swimmers be allowedto swim without lifeguards

8. Are signs effective at drowning prevention? If so, what are the most effective?

9. Why is drowning a "silent epidemic" that gets very little attention and funding?

10. What strategies are most effective in changing parental behavior surrounding supervision of children around water bodies?

11. What can water safety professionals do to enhance drowning prevention? (i.e., what are the most effective instructional methods?)

12. What resources are available to assist with reducing drowning deaths?

13. What is the parental role at an aquatic environment?

14. What critical skills are needed for self rescue?

15. Why do many people refuse to acknowledge potential drowning hazards?

16. Open water areas for swmming that are safer from hazards

17. What are others doing in terms of patron communication about drowning?

18. Would like to see a better research study done on the effect of formal swim lessons on the reduction of drowning deaths

19. What is the minimal skill requirement for swim instruction as a tool for preventing drowning. (survival swimming)

20. How to we get everyone on the same track, understanding the importance of reporting drownings, as drownings. For example, someone is rescued at the beach, and is taken to the hospital, where they later passed due to complications from drowning, but it is not reported as a drowning.

21. What is the best method to attempt to restore respiration to a drowning victim?

22. Why isn't there a national, comprehensive water safety message. Something like the

Safer 3 model that can address the global problem of drowning on several levels from national to individual families.

23. Measure effectiveness of various prevention strategies

24. How can more of the population be taught to swim?

25. How many individuals are drowning in lifeguarded aquatic facilities a year?

26. How does the lack of ACS classification of drowning as a trauma affect available data to understand drownings and to implement evidence-based injury prevention programs? What are the potential barriers and benefits to creating a parallel data collection set at the national level, or inclusion of drownings into trauma databases at the state and national level?

27. What evidence is there to support the effectiveness of scanning techniques in identifying patrons in need of assistance? 
28. Why aren't U.S. Coast Guard grant funds awarded to drowning prevention organizations that don't promote boating education?

29. How robust is the research infrastructure that supports systematic inquiry and data-driven decision-making within the field of drowning prevention

30. How does income inequality impact learning how to swim and/or drowning?

31. What is the effect of dry land eduction?

32. Compile data on reduction of drownings after first pool law passed in Contra Costa

County, California in 1984. Being the first in the world the study would show us how the law reduced drownings almost $100 \%$

33. Why is drowning prevention not taught in elementary schools?

34. Besides mandatory requirements and federal regulations, what programs/initiatives can be enacted to reduce drowning details in the United States?

35. How can drowning prevention and water safety education become an established curriculum in the public schools

36. why is underwater breath holding so dangerous? To include games, training activities such a bobs, distance underwater swims, walking on the bottom of the pool with or without weights, underwater tying activities, pushing weighted items along the bottom of the pool and such.

37. Why Technology in Aquatics is not well seen?

38. What positive outcomes are realized by participants in a Jr. Lifeguard program relative to fitness, decision making and self esteem?

39. Topic areas: Parent education, child/infant age group research, adolescent age group research, adult age group research

40. What is the compliance success as a result of the Virginia Graeme Baker Pool \& Spa Safety Act?

41. How can risk taking behavior in the neurological development of 13 - 21 age group be addressed in drowning education programming?

42. Age and sex of Victim

43. Effectivensss of curerent drowning prevention programs.

44. Do swim lessons have a protective effect against drowning for school-aged children?

45. How do we effect behavior change in parents/caregivers?

46. shallow water blackout

47. How accurate (i.e., valid and reliable) are current statistics on fatal and non-fatal drownings in the U.S. and other high income countries?

48. Why are there not more accurate statistics on fatal and non fatal drowinings

49. Do parents/caregivers know the top reasons why children drown?

50. School protocol for lifeguards on deck

51. learn to swim school education programs for public schools

52. Are signs currently being used for outdoor facilities easily interpreted, especially by hispanic and asian populations?

53. Cultural issues and how they impact drowning prevention education and practices

54. Effectiveness of swim lessons on drowning prevention

55. What is the effectiveness of current National Drowning Prevention and Water Safety Education programs and resources in increasing water safety awareness and reducing drowning rates for the general public across the Unite States in all aquatic environments. 
56. Why has the federal government not mandated water safety education and drowning prevention funding for elementary schools to teach every child in the United States how to swim or to achieve water competency?

57. Sex of victim

58. Why have we not backed Safer 3 more in schools - a pool is not needed?

59. What components are needed in a classroom water safety curriculum

60. How do we get the word out to a broad society where no water education now exists?

61. What skills must be achieved to qualify a person as a swimmer?

62. circumstances leading up to the drowning, who was home, drugs, priors, condition of the pool, did anone know CPR, how long was the child under water,

63. How long should a guard be allowed to work with out a break

64. Are regulations effective at drowning prevention? If so, what regulations are most effective?

65. Why does drowning continue to be "neglected public health issue" according to the World Health Organization?

66. What communication strategies are most effective at reaching specific target groups (e.g. males age 14 and older)

67. Historically, how has the cause of water accidents changed, and why?

68. What is the scope of water safety education in all areas of the country?

69. Are there any regulations that hold parents or guardians responsible in case of a preventable drowning at an aquatic facility?

70. What are the best methods to teach self rescue at various ages and stages of ability?

71. Is there a signifigant difference in drowning rates in areas/pools without lifeguards - how effective are lifeguards?

72. Clear and understandable warning signs where appropriate

73. What are effective methods for live staff testing/training, during operating hours?

74. Would like to see more current research done on baby swimming - specifically starting at birth or by two months

75. We currently have a research definition of drowning. What is the best definition of drowning for physiology, public health, prevention, etc...

76. How to easiest convince local goverments how important it is to create outreach programs about drowning prevention and water education?

77. Why do victims in the 1 to 3 year old range have a higher rate of losing spontaneous respiration than the rescue data would indicate?

78. Why isn't water safety education required in schools from pre-k through high school?

79. Learn to swim...> reduce drowning rates?

80. How do we get more boaters and swimmers to wear PFDs?

81. How many individuals are drowning in non-lifeguarded aquatic facilities a year?

82. How many ACES (Adverse Childhood Experiences) are present in parents who experience a fatal or nonfatal child or teen drowning? How many ACES are present in the victims? How do these ACES and a lack of stability contribute to drowning risk? What effect will it have upon education when injury prevention information is woven into programs and content to create stability in families?

83. How often do water safety skills and information need to be renewed to retain the knowledge and skills in an emergency situation? 
84. If the United States Government (USCG) is truely dedicated to reducing drowning deaths, why doesn't grant funds go only to the boating education organizations?

85. What strategies for increasing learners' willingness to participate in water safety training and education are most effective

86. Does water safety education inclusion into a child's overall education program help to decrease drowning?

87. Are urban Metro area parents less inclined to educate their children about water safety?

88. Compile data on reduction of child drownings in California after the Swimming Pool Safety Law was passed in 1996.

89. Who is at the greatest risk of fatal drowning?

90. What current drowning prevention programs are having a positive impact in reducing drowning deaths in the United States?

91. What water safety messages/themes motivates belief and behavior change?

92. What is the best way to educate all ages about ways to stay safe around the water

93. We have provided education outreach for years, and we havent made a dent in drownings.

94. Do facility's that have required lifejacket use rules achieve a lower incident rate of unconscious events involving children?

95. What are major contributing factor in drowning between child/infant, adolescent and adult age groups?

96. Are Water Watcher programs actually used and, if so, are they effective?

97. How does one address the panic component of non-intentional immersion in structured learned to swim lessons?

98. Type of water: pool, lake, ocean, river, etc.

99. Effectivenss of drwoning prevention programs in specific populations (ex. autism, ethnic/racial, etc.)

100. Does dry land/classroom based water safety education have a protective effect against drowning for school-aged children?

101. What is are the key factors in decision-making as it pertains to enrolling a child in swim lessons? Specifically for non-swimming parents.

102. identification of persons while drowning

103. How accurate (i.e., valid and reliable) are current statistics on fatal and non-fatal drownings in the U.S. and other high income countries?

104. Why is mandatory drowning prevention education embeded into school curriculums (elem)

105. What are layers of protection around swimming pools?

106. Swim team protocol for lifeguards on deck

107. access to swim lessons for the poor

108. How can we better articulate dangers of "attractive nuisance's"?

109. Minority focused research

110. Best age for swim lessons for drowning prevention

111. What is the current level of outreach and effectiveness in educating the general public in Drowning Prevention and Water Safety Education through current governmental agencies ( CPSC, CDC, State Health Departments, etc,) in educating and reducing drownings across the United States in swimming pools ( residential \& commercial) and open water drowning rates. 
112. More research is needed around increasing water safety education and swimming skills in minority communities (i.e. African-American and Hispanic/Latino communities)

113. Age of victim

114. $99 \%$ of child drownings are related to adult mistakes - no one seems to want to emphasize that

115. Is there a benefit of marketing the classroom curriculum as a pre-requisite to swimming lessons

116. Are swim lessons the best way to provide water education?

117. What skills must be achieved to qualify as a proficient swimmer?

118. What, if any, effect does handing out the same ole literature have

119. How does age affect attention span of a lifeguard

120. Are regulations regarding backyard pool fencing effective at drowning prevention? If so, what regulations are most effective?

121. There is a Stigma with drowning. Why do some professionals ignore it and fail to educate people about the stigma?

122. What are, statistically, the most common drowning/accidents in aquatic environments?

123. How do we measure the success of programs being delivered?

124. Do splash pads reduces the number of children drowning or increases?

125. What are effective methods of messaging for adults?

126. Are rural fire departments and other first responders adequately trained to respond to swift water and other water related emergencies?

127. Aggressive learn to swim programs throughout the country

128. What are advanced medical personnel looking for, in terms of first responder care, prior to them arriving on the scene? Is there documentation on best practices for this?

129. Would like to see research done on the impact of having water safety curriculum as a standard part of the $\mathrm{K}-12$ education

130. What are reasons that minority and low income children have higher drowning rates than age match peers?

131. How do we get fire officials, and police officials not to worry about the HIPAA law so much, when we ask for reports of drowning incidents? We can currently ask local governments for them through public records. We do not need name of the child/adult who drowned, or any other personal information, with the exception of the age. Important for studies.

132. What type of campaign would be required to convince parents that the presence of lifeguards does not preclude the necessity for parental supervision

133. Why isn't there more support for learning to swim beginning with infants and continuing trough adults. I?

134. Education / prevention v. active intervention

135. What are the best evidence based practices for lifeguards?

136. In the questions above we need to know the cause of the drowning.

137. How many parents have a solid and accurate perception of child development and how it affects drowning risk? How does correct/incorrect perception of child development influence parent behaviors and attitudes to reduce/increase drowning risk?

138. What impact does water safety education taught on land/in a classroom (not in an aquatic environment) have an a child's safety in, on or around the water?

139. Why doesn't the USCG recognize that good swimmers make better boaters? 
140. What are the societal costs and consequences of injury during aquatic activities, particularly those taking place outside a designated swimming area or in remote settings

141. Why do minority populations drown at higher rates as compared to majority populations?

142. What is the effect of swimming lessons with out a water safety education component?

143. In 1980 California Bureau of Vital Statistics showed children drowning ages 1 - 4 residential pools totaled 125 deaths....From that date to the year 2003 drownings dropped drastically year after year to a total of 25 deaths.! g

144. What type of water(ocean, river, lake pool etc) has the greatest number of fatalities?

145. Are there any mandatory requirements and federal regulations currently being proposed on a national level?

146. How can drowning prevention/water safety education be presented to at risk populations in order for them to gain knowledge and skills?

147. Does hypervenilation underwater breathholding assist lung capacity?

148. some groups believe that creating more instructors will reduce the drowning rate by $50 \%$

149. Does rotational task balance (alternation of scanning, non-scanning positions) produce a positive affect on lifeguard vigilance?

150. What are major the major training programs to address the different age populations from child/infant, adolescent, and adult?

151. What is the best role for parents or other family members who have lost children to a drowning or entrapment? Can they really be effective education providers and can they affect public policy change?

152. What are factors for effective learn to swim and water safety programming for mid to late teens?

153. Day of week, Time of day, Month

154. Effectiveness of water safety instructor programs.

155. Is there a specific age (range) when swim lessons have the most protective effect against drowning for children? If yes, what is that range?

156. What is the effectiveness of classroom-based water safety education versu in-water swim lessons as it relates to drownings? (i.e. Is classroom-based water safety education effective in preventing drowning deaths?)

157. What aquatic environments are most risking both for fatal and non-fatal drownings for different groups?

158. Why are most swimming programs in school districts taught 7-12 and not K-6?

159. What are the most effective barriers around swimming pools?

160. water safety education in schools

161. How can we get parents to treat downing prevention in a similar fashion as we do for seat belt safety?

162. Data surveillance gaps

163. Effectiveness of parental education for drowning prevention

164. What is the effectiveness of current Local State Coalitions in Drowning Prevention And are these focused coalitions what is the effectiveness in increasing water safety and drowning prevention education in their communities and have they reduced Drownings and water related injuries through their advocacy, education and outreach in their targeted areas and communities they are active in.

165. More research is needed to understand perceived barriers of participation in aquatic activities within minority groups 
166. Depth ofwater

167. 1/3 of all adult drowninbgs are alcohol related yet I havent seen any one asking ofr help from Alcohol manufacturers for a national awareness campaign

168. How do we incorporate the many needed messages so not to confuse the community

169. What social groups are at greatest risk - i.e. number of drownings?

170. What scientific evidence shows parent water safety education prevents child drowning?

171. what message is being heard, there are 100 different to do's but hwat actually gets in the minds and creates change in behavior. My guess is that until there are consequences for the behavior nothing will ever change. Much like wearing seat belts

172. How dagerous is lightning

173. Are lifeguards effective at drowning prevention?

174. Why are there so many incorrect drowning images on signs at beaches and pools?

175. What are the most obvious/most significant risk factors associated with drowning/water accidents?

176. Why the Aquatic facilities aren't required to provide life jackets to the non-swimmers?

177. What is a practical and actionable definition of supervision around water?

178. Appreciation of the power of moving water

179. Would like to see comparative research done between the U.S. and global areas who are surrounded by water but do not have the drowning problem we do such as Scandinavian countries

180. What is optimal legislative strategy for pool fencing that translates into cost-effective drowning prevention programs.

181. What is the most efficient way to educate parents and care givers about water safety, and drowning prevention?

182. Why is there no longer a national coalition such as the defunct Council for National Cooperation in Aquatics of major agencies sharing information on the prevention of drowning.

183. Why isn't there more concern for the amount of stress that infants and toddlers are subjected to in "survival" type swim instruction.

184. Socio-economic factors?

185. Where in the US has drowning rates decreased dramatically and why?

186. What are the demographics of families who experience fatal and nonfatal child and teen drownings? Are the CDC's risk factors for vulnerable populations (poverty, multigenerational living, low maternal age, etc) present at increased rates? How should drowning prevention efforts target these populations?

187. How and what should we be teaching to have the greatest impact with the public regarding water safety and reducing the incidence of drowning? Should the focus and energy be to educate children, or parents, or grandparents - what method and topics will have the most impact on teaching drowning prevention? What can we learn from national safety campaigns like bicycle helmet safety or seat belt safety campaigns?

188. Why isn't the lack of swimming ability recognized as a leading cause of boating fatalities?

189. What is the impact of legislation, litigation, and regulation on the availability and variety of aquatics programming

190. What programming can encourage more parents to believe that swimming is a necessary lifeskill for their child(ren)? 
191. Around 1980 children residing in California State Hospitals averaged 250...Last year 2015 totaled over 700 . Keeping children alive after incidents that were dying many years ago. Try to get information similar from other states with high death rates in the 1-4 age group.

192. What programs have a high success rate in reducing drowning fatalaites

193. How can universal "learn to swim" initatives among preschool age children be encouraged and taught especially in the minority communities?

194. what is the one skill children need to to help save their life (floating, treading, swimming,etc)

195. Do facility's that implment process of open airway/rescue breathing in the water realized improved outcomes in unconscious events?

196. What are the current gaps between major contributing factors and training/prevention in drowning across the age groups; child/infant, adolescent and adult?

197. The CPSC's Pool Safely Campaign--good, bad or ugly? Is it effective and can it do better?

198. How can fields neuroscience and brain development be used to improve the effectiveness of lifeguards 16 - 21?

199. Supervision- who, how did it break down

200. Is there a specific age (range) when dry land/classroom based water safety education has a protective effective against drowning for children? If yes, what it that age (range)?

201. Do swimming lessons improve academic performance and classroom behaviours?

202. What role do different levels of water competence (a.k.a., swimming skill level) play in preventing fatal and non-fatal drownings?

203. Why is water safety not emphsized over first in learn to swim?

204. What is the best age to begin children's swim lessons?

205. swimming pool open days (free entry with free swim lessons) for the community

206. How do we get school systems to embrace the need for water safety/drowning prevention?

207. Early intervention programs

208. Lifeguard scanning effectiveness

209. What are the curriculum requirements for each state and the common core for health education and physical education in regards to water safety and drowning prevention.

210. Type of water - pool, beach, lake, etc.

211. Is there one message that would work in drowning prevention?

212. Funding is always an issue - how will funding occur for a broad program?

213. What barriers provide the greatest degree of child drowning prevention?

214. There has been little to no research in what happens to the child once they fall in. Our M. E. feels he can tell how long the child has been under the water, debunking the myth that the child was only basent for less than a minute. Here in Broward we have proved the child was under water for 40-60 minutes when the parent says they were just gone for less than a minute. Taking hte parent's word for events is a mistake. We don't for any other death but we do for drowning

215. What is the a reasonable policy on lightning in a opnen water envirnment

216. At what age is it best to target drowning prevention messaging?

217. How can these factors in my q \#4 be minimized or limited?

218. Does wearing a Certified life jacket prevent a drowning of a non-swimmer? 
219. Are short duration "swim lesson" programs presented as drowning prevention outreach projects effective in teaching relevant self rescue skills?

220. Greater cooperation between water sports activities and learn to swim programs

221. Would like to see research done on the impact of having effective enforcement of barrier

laws

222. What is true burden of nonfatal drowning, both with and without morbidity?

223. Children and adults with autism are drawn to the water, and is a high risk group. We need more organizations to certify water safety instructor with a special needs certifcation, so we can meet the high demand of special needs children that want to learn how to swim.

224. In lifeguarding, what is the distance of the victim from the guard?

225. Why do we see the same type of messaging that while raising awareness, does little to bring about change in behavior and responsibility for prevention. We need to change the status quo as to the way people think while increasing the generational approach by education the young in all school systems.

226. Effectiveness of signage/flag systems at beaches

227. What kind of intervention programs have been successful?

228. How many existing drowning prevention programs focus upon educating children? How many focus upon adults, conduct effective evaluation, and evolve with new research findings, and contribute to the body of knowledge about drownings and how to prevent them?

229. How long should a lifeguard be assigned to continually watch the water before interruption of duty?

230. If a person drowns while attempting to retrieve their vessel, why isn't it classified as a boating accident? If a person drowns while swimming around their vessel, why is isn't it classified as a boating accident?

231. Which environmental, behavioral, and legislative or regulatory interventions to improve water safety are most effective

232. What information needs to be included into "learn to swim" and WSI curricula?

233. Under age four most drowning deaths occurred in home bath tubs. Either left alone or with a sibling. This is an event that is clearly preventable! Need public awareness continued. 234. How can drowning prevention/water safety become a part of a parenting course for 235. where and when should the public start being educated (grade school, hospital before they leave with their new baby, high school, workforce, etc)

236. Do facility's that implement Zone Validation (Zone of Patron Surveillance) based staffing experience a decreased number of unconscious aquatic events?

237. How does the drowning and entrapment prevention community better address residential drownings and the potentioal for entrapments (safety devices, portable, large pools......)?

238. Meta-Analysis of open water drowning risk reduction programs?

239. Depth of water

240. If it is found that swim lessons do not have a protective effect against drowning for school-aged children, is there a significant single most common factor that is a protective factor to prevent drowning in children?

241. What percentage of the U.S. population, by age group, has a basic understanding of water safety AND water safety skills?

242. How are different levels of water competence associated with different aquatic environments and conditions?

243. Why are lifeguards not required at all swimming facilities? 
244. What are the drowning prevention strategies for each age group?

245. How doe we get drowning prevention awareness into all elementary schools? Much like fire safety, danger ranger, etc.?

246. evaluation of standard tools...e.g. Water Watcher Tags

247. What are the most effective programs and delivery methods for reducing childhood drownings in public education.

248. Day and time 


\section{Appendix H}

\section{Consensus Building Round 2 Survey}

Email Please enter the e-mail address in-which you are receiving communication regarding this study:

PURPOSE: The purpose of this study is to identify and rate the importance of potential outstanding research questions surrounding drowning prevention education in the United States.

DIRECTIONS: You will now be presented with the list of developed research questions from the first round of data collection. Two hundred and forty eight responses were submitted in the first data collection period and have been synthesized into 101 research questions. In this round of data collection you will be asked to rate each question on a level of importance scale. Please rate each question independently from other questions. If a question receives a mean group rating higher than "Very Important" it will be considered as meeting consensus as a highly important question and will be excluded from the final round of data collection. Please use the arrows on the bottom of each page to navigate through the survey.

DIRECTIONS: Please rate the following items on level of importance. Your rating should reflect your personal opinion on the importance of each question being studied.

PROMPT: "How important is it that we answer each particular question?" 


\begin{tabular}{|c|c|c|c|c|c|c|c|}
\hline & $\begin{array}{l}\text { Not at all } \\
\text { important } \\
\text { (1) }\end{array}$ & $\begin{array}{c}\text { Low } \\
\text { importance } \\
\text { (2) }\end{array}$ & $\begin{array}{l}\text { Slightly } \\
\text { Important } \\
\text { (3) }\end{array}$ & $\begin{array}{l}\text { Neutral } \\
\text { (4) }\end{array}$ & $\begin{array}{l}\text { Moderately } \\
\text { Important } \\
\text { (5) }\end{array}$ & $\begin{array}{c}\text { Very } \\
\text { Important } \\
\text { (6) }\end{array}$ & $\begin{array}{l}\text { Extremely } \\
\text { Important } \\
\text { (7) }\end{array}$ \\
\hline $\begin{array}{l}\text { 1. What } \\
\text { protective } \\
\text { effects (if any) } \\
\text { against } \\
\text { drowning exist } \\
\text { after swim } \\
\text { lessons/learning } \\
\text { to swim remain } \\
\text { across the } \\
\text { lifespan? (1) }\end{array}$ & 0 & 0 & 0 & $O$ & 0 & 0 & $\mathrm{O}$ \\
\hline $\begin{array}{l}\text { 2. What role do } \\
\text { different levels } \\
\text { of water } \\
\text { competence } \\
\text { (a.k.a., } \\
\text { swimming skill } \\
\text { level) play in } \\
\text { preventing fatal } \\
\text { and non-fatal } \\
\text { drownings? (2) }\end{array}$ & 0 & 0 & 0 & 0 & 0 & 0 & 0 \\
\hline $\begin{array}{l}\text { 3. What are } \\
\text { critical skills } \\
\text { are needed for } \\
\text { self-rescue? (3) }\end{array}$ & 0 & 0 & 0 & 0 & 0 & 0 & 0 \\
\hline $\begin{array}{l}\text { 4. What is the } \\
\text { best age to } \\
\text { begin children's } \\
\text { swim lessons? } \\
\text { (4) }\end{array}$ & 0 & 0 & 0 & 0 & 0 & 0 & 0 \\
\hline $\begin{array}{l}\text { 5. What is the } \\
\text { specific age } \\
\text { (range) when } \\
\text { swim lessons } \\
\text { have the most } \\
\text { protective } \\
\text { effect against } \\
\text { drowning for } \\
\text { children? (5) }\end{array}$ & 0 & 0 & 0 & 0 & 0 & 0 & 0 \\
\hline
\end{tabular}




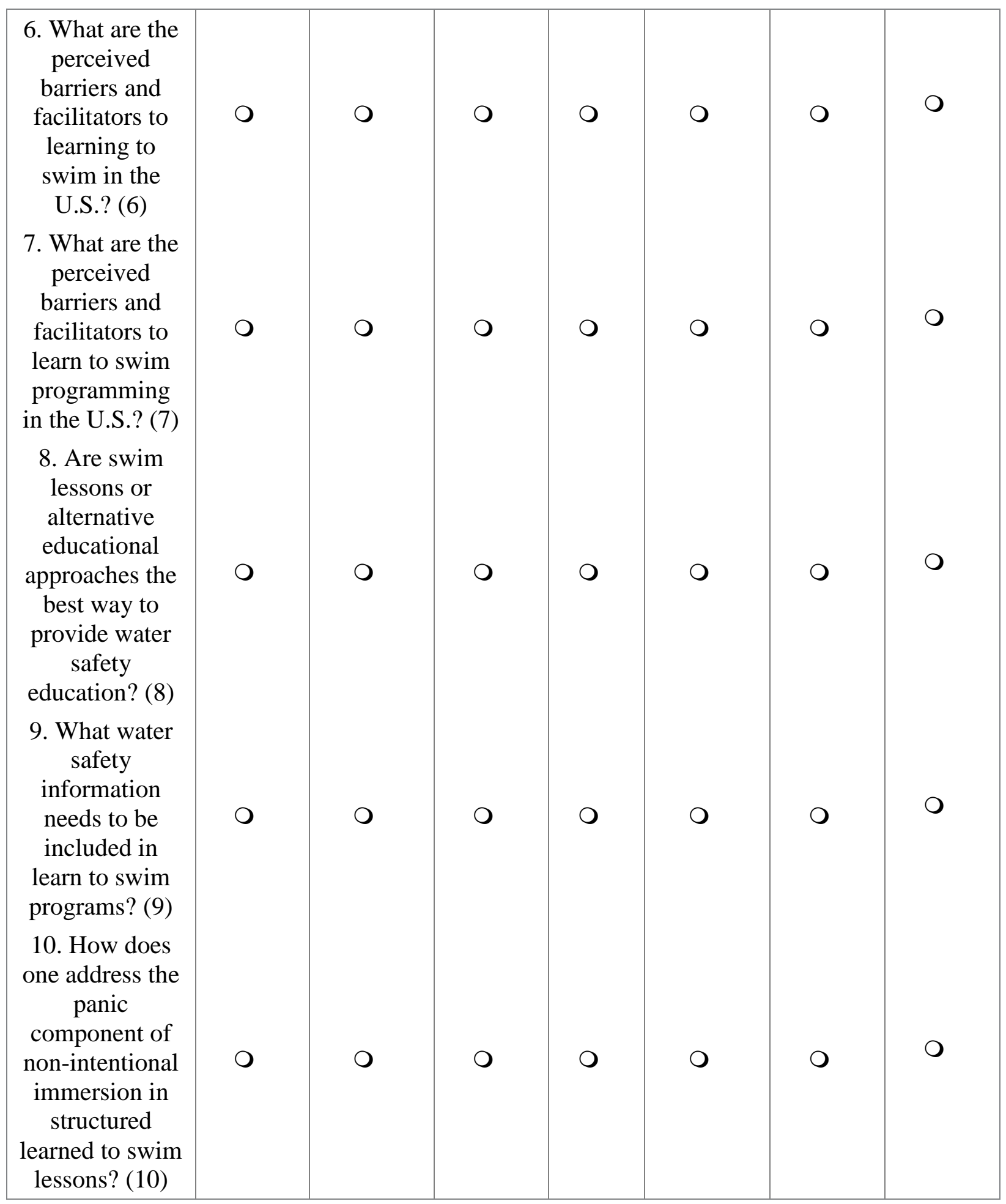




\begin{tabular}{|c|c|c|c|c|c|c|c|}
\hline $\begin{array}{l}\text { 11. What are } \\
\text { the components } \\
\text { for effective } \\
\text { learn to swim } \\
\text { and water } \\
\text { safety } \\
\text { programming } \\
\text { for adolescents } \\
\text { and adults? (11) }\end{array}$ & 0 & 0 & 0 & 0 & 0 & 0 & 0 \\
\hline $\begin{array}{l}\text { 12. What are } \\
\text { the positive and } \\
\text { negative effects } \\
\text { of short } \\
\text { duration } \\
\text { swimming } \\
\text { lessons on } \\
\text { drowning } \\
\text { prevention } \\
\text { knowledge and } \\
\text { water safety } \\
\text { skills? (12) }\end{array}$ & 0 & 0 & 0 & 0 & 0 & 0 & 0 \\
\hline $\begin{array}{l}\text { 13. What are } \\
\text { the positive and } \\
\text { negative effects } \\
\text { of infant based } \\
\text { water survival } \\
\text { training? (13) }\end{array}$ & 0 & 0 & 0 & 0 & 0 & 0 & 0 \\
\hline $\begin{array}{l}\text { 14. What are } \\
\text { the most } \\
\text { effective } \\
\text { methods to } \\
\text { teach self- } \\
\text { rescue at } \\
\text { various ages } \\
\text { and stages of } \\
\text { ability? (14) }\end{array}$ & 0 & 0 & 0 & 0 & 0 & 0 & 0 \\
\hline
\end{tabular}




\begin{tabular}{|c|c|c|c|c|c|c|c|}
\hline & $\begin{array}{c}\text { Not at all } \\
\text { importan } \\
\text { t (1) }\end{array}$ & $\begin{array}{c}\text { Low } \\
\text { importanc } \\
\text { e (2) }\end{array}$ & $\begin{array}{c}\text { Slightly } \\
\text { Importan } \\
\text { t (3) }\end{array}$ & $\begin{array}{l}\text { Neutra } \\
\text { I (4) }\end{array}$ & $\begin{array}{c}\text { Moderatel } \\
y \\
\text { Important } \\
\text { (5) }\end{array}$ & $\begin{array}{c}\text { Very } \\
\text { Importan } \\
\text { t (6) }\end{array}$ & $\begin{array}{c}\text { Extremely } \\
\text { Importan } \\
\text { t (7) }\end{array}$ \\
\hline $\begin{array}{l}\text { 15. What current } \\
\text { resources exist to } \\
\text { educate the } \\
\text { public on } \\
\text { drowning } \\
\text { prevention and } \\
\text { are those } \\
\text { resources } \\
\text { effective? (1) }\end{array}$ & 0 & 0 & 0 & 0 & 0 & 0 & 0 \\
\hline $\begin{array}{l}\text { 16. How can the } \\
\text { effectiveness of } \\
\text { drowning } \\
\text { prevention } \\
\text { education } \\
\text { programs be } \\
\text { measured? (2) }\end{array}$ & 0 & 0 & 0 & 0 & 0 & 0 & 0 \\
\hline $\begin{array}{l}\text { 17. At what age } \\
\text { group (i.e. } \\
\text { children, or } \\
\text { parents, or } \\
\text { grandparents) } \\
\text { should drowning } \\
\text { prevention } \\
\text { education be } \\
\text { focused on or is } \\
\text { there a best way } \\
\text { to educate all } \\
\text { ages } \\
\text { simultaneously? } \\
\text { (3) }\end{array}$ & 0 & 0 & 0 & 0 & 0 & 0 & 0 \\
\hline $\begin{array}{l}\text { 18. How often do } \\
\text { water safety } \\
\text { skills and } \\
\text { information need } \\
\text { to be refreshed to } \\
\text { retain the } \\
\text { knowledge and } \\
\text { skills in an } \\
\text { emergency } \\
\text { situation by lay } \\
\text { responders? (4) }\end{array}$ & 0 & 0 & 0 & 0 & 0 & 0 & 0 \\
\hline
\end{tabular}




\begin{tabular}{|c|c|c|c|c|c|c|c|}
\hline $\begin{array}{l}\text { 19. What is the } \\
\text { prevalence and } \\
\text { impact of "water- } \\
\text { watcher" } \\
\text { programs in the } \\
\text { U.S.?" (5) } \\
\text { 20. What is the } \\
\text { impact of local } \\
\text { coalitions/task } \\
\text { forces on the } \\
\text { reduction of } \\
\text { water-related } \\
\text { injuries/fatalities } \\
\text { ? (6) } \\
\text { 21. What is the } \\
\text { impact of } \\
\text { legislation and } \\
\text { regulation on the } \\
\text { availability and } \\
\text { variety of } \\
\text { aquatics } \\
\text { programming? } \\
\text { (7) } \\
\text { 22. What } \\
\text { prevention/water } \\
\text { to all ages? (10) } \\
\text { strategies can } \\
\text { increase public } \\
\text { awareness around } \\
\text { the risk of } \\
\text { bathtub } \\
\text { drownings? (8) } \\
\text { 23. What can be } \\
\text { done to increase } \\
\text { public } \\
\text { recognition of } \\
\text { drowning as a } \\
\text { public health } \\
\text { issue? (9) } \\
\text { 24. When and } \\
\text { where is the most } \\
\text { effective time } \\
\text { and place to }\end{array}$ & 0 & 0 & 0 & 0 & 0 & 0 & 0 \\
\hline
\end{tabular}




\begin{tabular}{|c|c|c|c|c|c|c|c|}
\hline $\begin{array}{l}25 . \text { What is the } \\
\text { reach and scope } \\
\text { of current } \\
\text { drowning } \\
\text { prevention/water } \\
\text { safety education } \\
\text { programs in the } \\
\text { U.S.? (11) }\end{array}$ & 0 & 0 & 0 & 0 & 0 & 0 & 0 \\
\hline
\end{tabular}




\begin{tabular}{|c|c|c|c|c|c|c|c|}
\hline & $\begin{array}{l}\text { Not at all } \\
\text { importan } \\
\text { t (1) }\end{array}$ & $\begin{array}{c}\text { Low } \\
\text { importanc } \\
\text { e (2) }\end{array}$ & $\begin{array}{c}\text { Slightly } \\
\text { Importan } \\
\text { t (3) }\end{array}$ & $\begin{array}{c}\text { Neutra } \\
\text { I (4) }\end{array}$ & $\begin{array}{c}\text { Moderatel } \\
\text { y } \\
\text { Important } \\
\text { (5) }\end{array}$ & $\begin{array}{c}\text { Very } \\
\text { Importan } \\
\text { t (6) }\end{array}$ & $\begin{array}{c}\text { Extremel } \\
y \\
\text { Importan } \\
\mathrm{t}(7)\end{array}$ \\
\hline $\begin{array}{l}\text { 26. Have } \\
\text { environmental, } \\
\text { behavioral, and } \\
\text { legislative or } \\
\text { regulatory } \\
\text { interventions } \\
\text { reduced fatal/non- } \\
\text { fatal drownings? } \\
\text { (1) } \\
\text { 27. What } \\
\text { programs/initiative } \\
\text { s, besides } \\
\text { mandatory } \\
\text { requirements and } \\
\text { federal regulations, } \\
\text { can be enacted to } \\
\text { reduce drowning } \\
\text { deaths in the U.S.? } \\
\text { (2) } \\
\text { 28. How can the } \\
\text { dangers of } \\
\text { "attractive } \\
\text { nuisances" be } \\
\text { better articulated? } \\
\text { (3) } \\
\text { high drowning } \\
\text { rates? (5) } \\
\text { ace. How can the } \\
\text { accuracy of current } \\
\text { statistics on fatal } \\
\text { and non-fatal } \\
\text { drownings in the } \\
\text { U.S. be improved? } \\
\text { (4) } \\
\text { 30. What } \\
\text { similarities exist } \\
\text { between the U.S. } \\
\text { and countries } \\
\text { atho report }\end{array}$ & 0 & 0 & 0 & 0 & 0 & 0 & 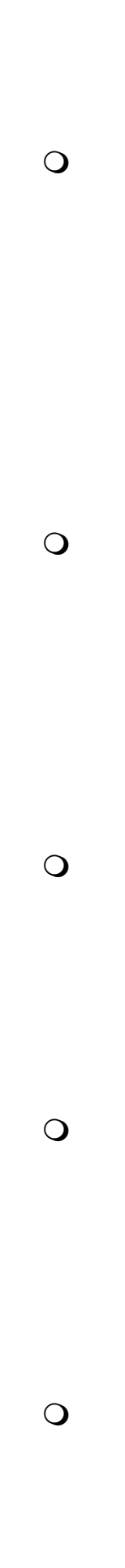 \\
\hline
\end{tabular}




\begin{tabular}{|c|c|c|c|c|c|c|c|}
\hline $\begin{array}{l}\text { 31. Are there } \\
\text { specific regions or } \\
\text { local areas where } \\
\text { drowning rates } \\
\text { have decreased } \\
\text { significantly, and if } \\
\text { so why? (6) } \\
\text { 32. What is the } \\
\text { economic and } \\
\text { societal impact of } \\
\text { nonfatal drowning? } \\
\text { (7) } \\
\text { 33. How does the } \\
\text { lack of an } \\
\text { American College } \\
\text { of Surgeons trauma } \\
\text { classification for } \\
\text { drowning limit the } \\
\text { understanding of } \\
\text { data and the } \\
\text { implementation of } \\
\text { evidence-based } \\
\text { injury prevention } \\
\text { programs? (8) } \\
\text { 34. What are the } \\
\text { potential barriers } \\
\text { and benefits to the } \\
\text { implementation of } \\
\text { a universal data } \\
\text { collection system at } \\
\text { the national level, } \\
\text { or inclusion of } \\
\text { drownings into } \\
\text { existing trauma } \\
\text { databases at the } \\
\text { state and national } \\
\text { level? (9) }\end{array}$ & 0 & 0 & 0 & 0 & 0 & 0 & 0 \\
\hline
\end{tabular}




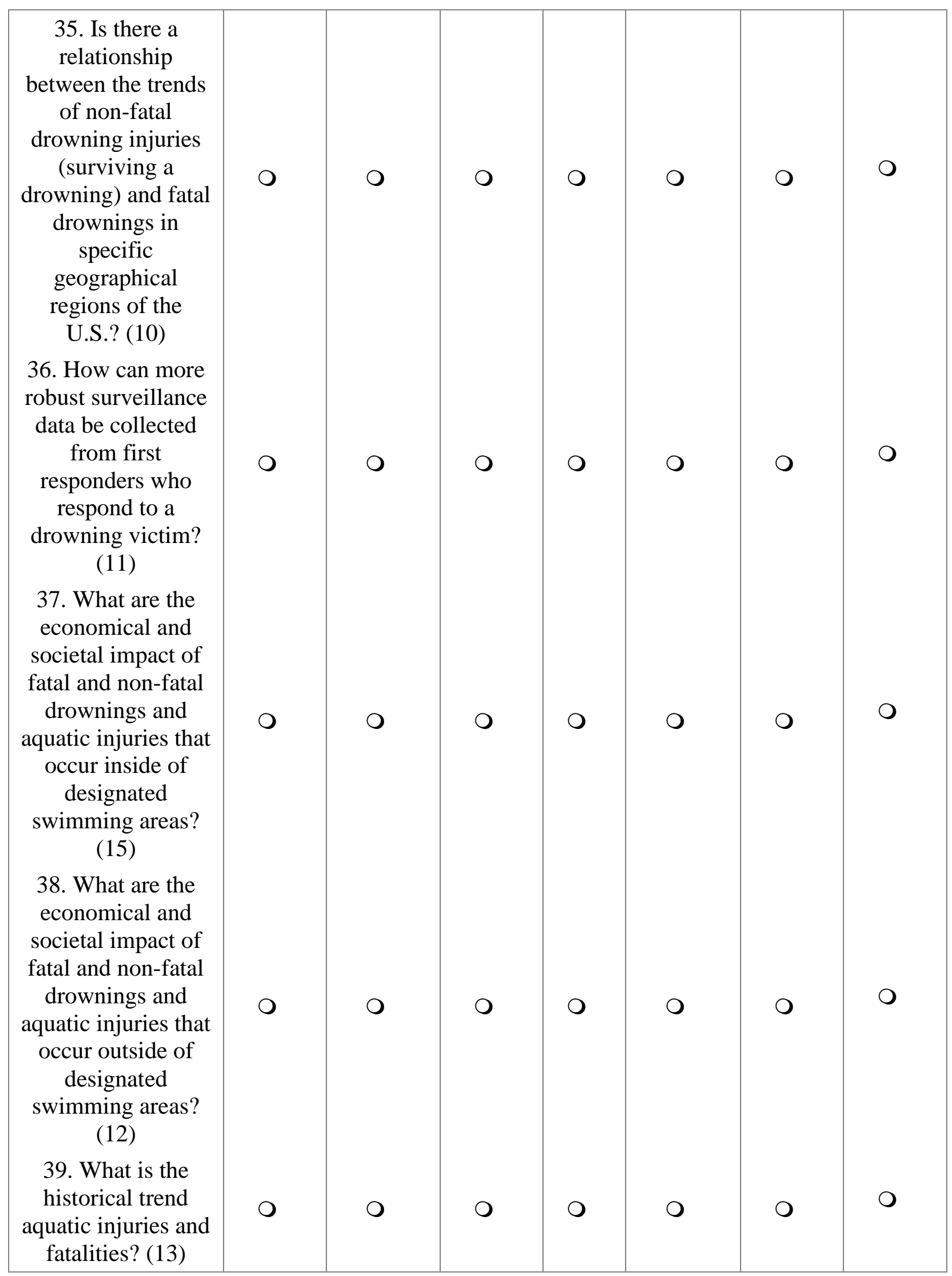




\begin{tabular}{|c|c|c|c|c|c|c|c|}
\hline $\begin{array}{l}\text { 40. How robust is } \\
\text { the research } \\
\text { infrastructure that } \\
\text { supports inquiry } \\
\text { and data-driven } \\
\text { decision-making } \\
\text { within the field of } \\
\text { drowning } \\
\text { prevention? (14) }\end{array}$ & 0 & 0 & 0 & 0 & 0 & 0 & 0 \\
\hline
\end{tabular}




\begin{tabular}{|c|c|c|c|c|c|c|c|}
\hline & $\begin{array}{c}\text { Not at all } \\
\text { importan } \\
\mathrm{t}(1)\end{array}$ & $\begin{array}{c}\text { Low } \\
\text { importanc } \\
\text { e (2) }\end{array}$ & $\begin{array}{l}\text { Slightly } \\
\text { Importan } \\
\text { t (3) }\end{array}$ & $\begin{array}{c}\text { Neutra } \\
\text { I (4) }\end{array}$ & $\begin{array}{c}\text { Moderatel } \\
y \\
\text { Important } \\
\text { (5) }\end{array}$ & $\begin{array}{c}\text { Very } \\
\text { Importan } \\
\text { t (6) }\end{array}$ & $\begin{array}{c}\text { Extremely } \\
\text { Importan } \\
\text { t (7) }\end{array}$ \\
\hline $\begin{array}{l}\text { 41. What impact } \\
\text { does parent } \\
\text { education of } \\
\text { water safety have } \\
\text { on child } \\
\text { drowning } \\
\text { prevention? (1) }\end{array}$ & 0 & 0 & 0 & 0 & 0 & 0 & 0 \\
\hline $\begin{array}{c}\text { 42. What } \\
\text { strategies are } \\
\text { most effective in } \\
\text { increasing } \\
\text { parental } \\
\text { supervision of } \\
\text { children around } \\
\text { bodies of water? } \\
\text { (2) }\end{array}$ & 0 & 0 & 0 & 0 & 0 & 0 & 0 \\
\hline $\begin{array}{l}\text { 43. What do } \\
\text { parents/caregiver } \\
\text { s believe their } \\
\text { role is in an } \\
\text { aquatic } \\
\text { environment? (3) }\end{array}$ & 0 & 0 & 0 & 0 & 0 & 0 & 0 \\
\hline $\begin{array}{l}\text { 44. What are } \\
\text { parent } \\
\text { perceptions of } \\
\text { and motivations } \\
\text { for enrolling a } \\
\text { child in swim } \\
\text { lessons? (4) }\end{array}$ & 0 & 0 & 0 & 0 & 0 & 0 & 0 \\
\hline $\begin{array}{l}\text { 45. What can be } \\
\text { done to increase } \\
\text { parental } \\
\text { supervision when } \\
\text { lifeguards are } \\
\text { present? (5) }\end{array}$ & 0 & 0 & 0 & 0 & 0 & 0 & 0 \\
\hline
\end{tabular}




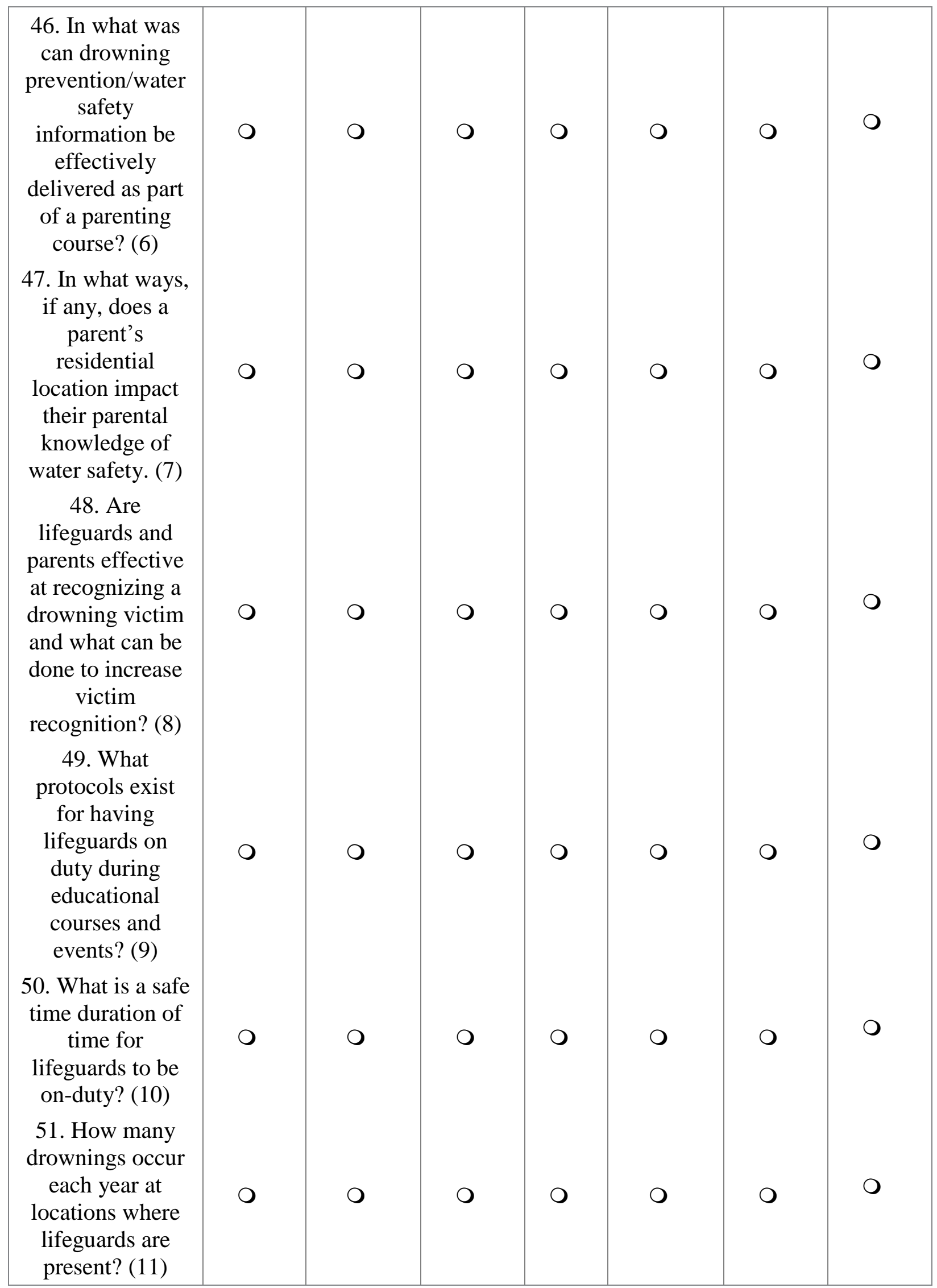




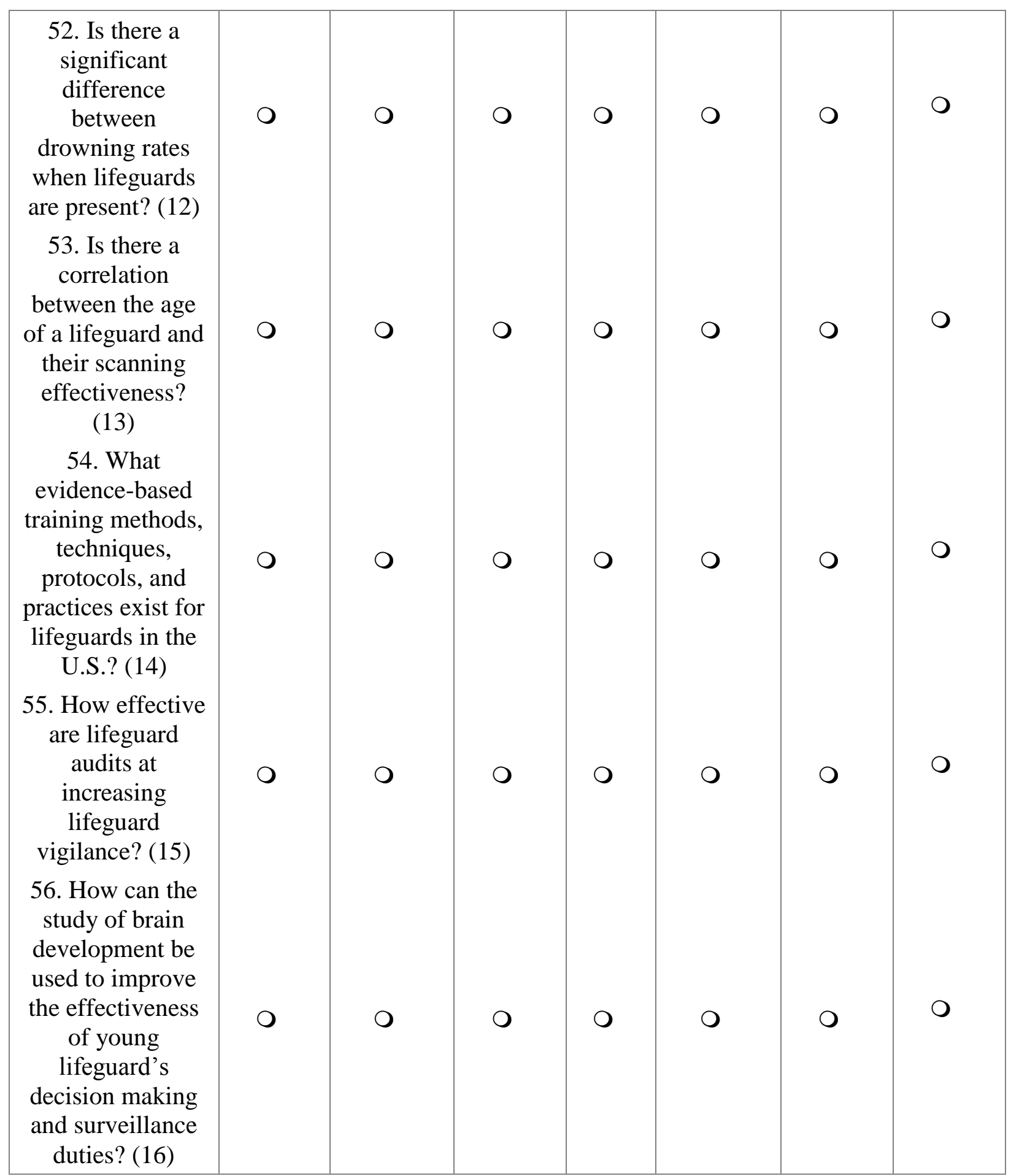




\begin{tabular}{|c|c|c|c|c|c|c|c|}
\hline & $\begin{array}{l}\text { Not at all } \\
\text { importan } \\
\mathrm{t}(1)\end{array}$ & $\begin{array}{l}\text { Low } \\
\text { importanc } \\
\text { e (2) }\end{array}$ & $\begin{array}{l}\text { Slightly } \\
\text { Importan } \\
\text { t (3) }\end{array}$ & $\begin{array}{c}\text { Neutra } \\
\text { I (4) }\end{array}$ & $\begin{array}{c}\text { Moderatel } \\
y \\
\text { Important } \\
\text { (5) }\end{array}$ & $\begin{array}{c}\text { Very } \\
\text { Importan } \\
t(6)\end{array}$ & $\begin{array}{c}\text { Extremel } \\
y \\
\text { Importan } \\
t(7)\end{array}$ \\
\hline $\begin{array}{l}\text { 57. To what extent } \\
\text { is underwater } \\
\text { breath holding } \\
\text { dangerous? (1) }\end{array}$ & 0 & 0 & 0 & 0 & 0 & 0 & 0 \\
\hline $\begin{array}{l}\text { 58. What is } \\
\text { shallow water } \\
\text { blackout and to } \\
\text { what extent should } \\
\text { prevention efforts } \\
\text { attempt to reduce } \\
\text { the risk? (2) }\end{array}$ & 0 & 0 & 0 & 0 & 0 & 0 & 0 \\
\hline $\begin{array}{l}\text { 59. What can be } \\
\text { done to reduce } \\
\text { alcohol usage } \\
\text { around water? (3) }\end{array}$ & 0 & 0 & 0 & 0 & 0 & 0 & 0 \\
\hline $\begin{array}{l}60 . \text { What are the } \\
\text { psychological and } \\
\text { physiological } \\
\text { responses when a } \\
\text { person begins to } \\
\text { drown? (4) }\end{array}$ & 0 & 0 & 0 & 0 & 0 & 0 & 0 \\
\hline $\begin{array}{l}\text { 61. How can the } \\
\text { use of drowning } \\
\text { prevention and } \\
\text { water safety } \\
\text { technology } \\
\text { increase? (5) }\end{array}$ & 0 & 0 & 0 & 0 & 0 & 0 & 0 \\
\hline $\begin{array}{l}\text { 62. To what extent } \\
\text { are specific } \\
\text { variables (i.e. } \\
\text { supervision, drug } \\
\text { and alcohol use, } \\
\text { prior convictions, } \\
\text { conditions of } \\
\text { water, prevention } \\
\text { and rescue training, } \\
\text { time child was } \\
\text { missing) associated } \\
\text { with drowning? (6) }\end{array}$ & 0 & 0 & 0 & 0 & 0 & 0 & 0 \\
\hline
\end{tabular}




\begin{tabular}{|c|c|c|c|c|c|c|c|}
\hline $\begin{array}{l}\text { 63. What barriers } \\
\text { exist for drowning } \\
\text { prevention and } \\
\text { water safety } \\
\text { education in K-12 } \\
\text { schools across the } \\
\text { U.S.? (7) } \\
\text { 64. What effective } \\
\text { approaches to } \\
\text { teaching drowning } \\
\text { prevention and } \\
\text { water safety } \\
\text { education in K-12 } \\
\text { schools across the } \\
\text { U.S.? (8) } \\
\text { 65. Is dryland- } \\
\text { based water safety } \\
\text { education more or } \\
\text { less effective than } \\
\text { in water-based } \\
\text { education? (9) } \\
\text { 66. What, if any, } \\
\text { effect does } \\
\text { including water } \\
\text { safety in a K-12 } \\
\text { school's } \\
\text { curriculum have on } \\
\text { the reduction of } \\
\text { drowning risk? } \\
\text { (10) } \\
\text { 67. What } \\
\text { s regarding water } \\
\text { safety/drowning } \\
\text { prevention } \\
\text { education? (11) } \\
\text { requirements exist } \\
\text { by state health and } \\
\text { shysical education } \\
\text { standards/objective }\end{array}$ & 0 & 0 & 0 & 0 & 0 & 0 & 0 \\
\hline
\end{tabular}




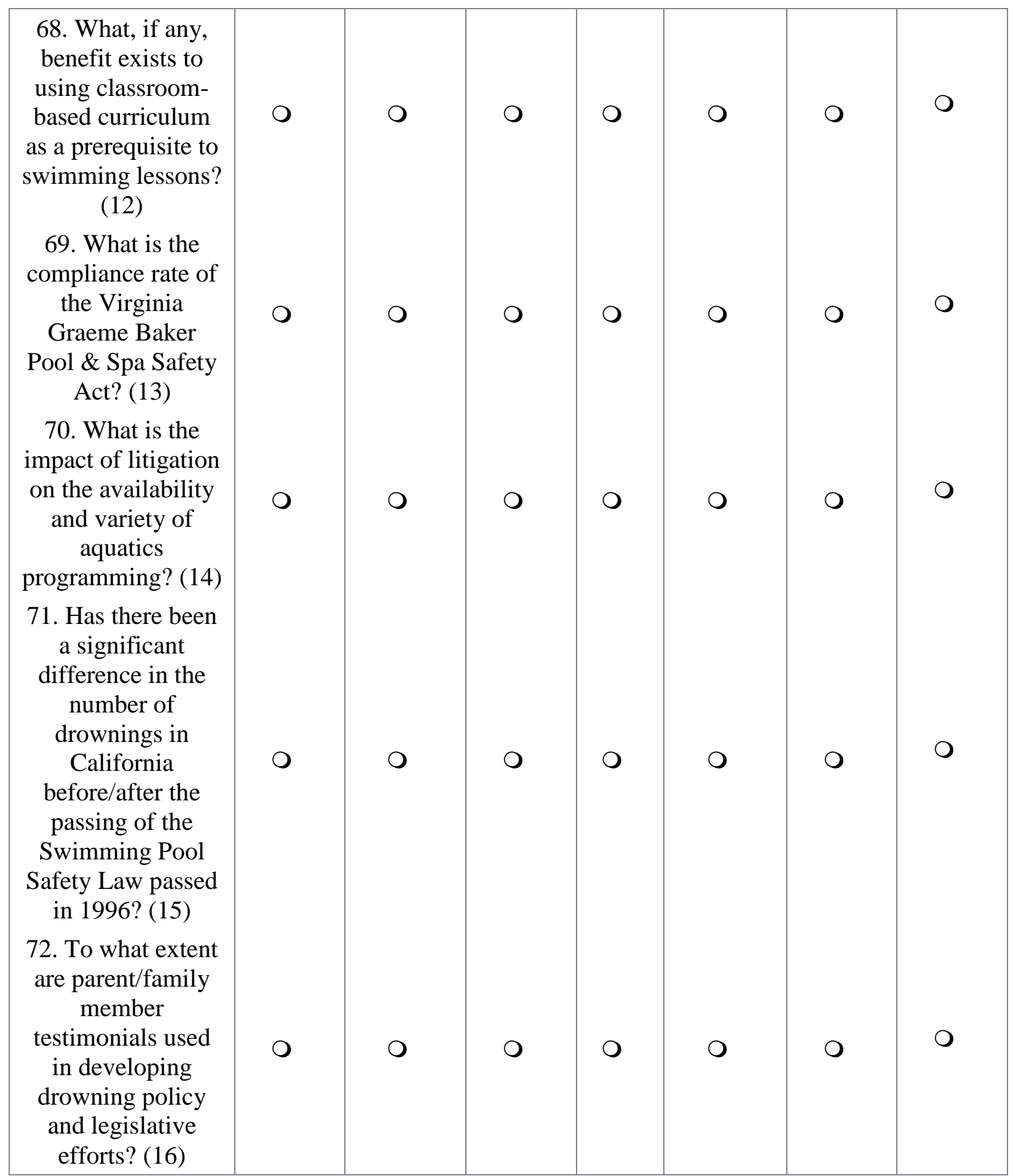




\begin{tabular}{|c|c|c|c|c|c|c|c|}
\hline & $\begin{array}{c}\text { Not at all } \\
\text { importan } \\
t(1)\end{array}$ & $\begin{array}{c}\text { Low } \\
\text { importanc } \\
\text { e (2) }\end{array}$ & $\begin{array}{l}\text { Slightly } \\
\text { Importan } \\
\text { t (3) }\end{array}$ & $\begin{array}{l}\text { Neutra } \\
\text { I (4) }\end{array}$ & $\begin{array}{l}\text { Moderatel } \\
y \\
\text { Important } \\
\text { (5) }\end{array}$ & $\begin{array}{c}\text { Very } \\
\text { Importan } \\
\text { t (6) }\end{array}$ & $\begin{array}{c}\text { Extremel } \\
y \\
\text { Importan } \\
t(7)\end{array}$ \\
\hline $\begin{array}{l}\text { 73. What are the } \\
\text { most common } \\
\text { drowning/accident } \\
\mathrm{s} \text { in aquatic } \\
\text { environments? (1) }\end{array}$ & 0 & 0 & O & 0 & ○ & 0 & 0 \\
\hline $\begin{array}{l}\text { 74. What aquatic } \\
\text { environments (i.e., } \\
\text { pool, spa, lake, } \\
\text { river, ocean) have } \\
\text { the greatest } \\
\text { number of aquatic } \\
\text { injuries/fatalities? } \\
\text { (2) }\end{array}$ & O & 0 & $\mathrm{O}$ & 0 & $\mathrm{O}$ & 0 & 0 \\
\hline $\begin{array}{l}75 . \text { In regards to } \\
\text { lightning what is a } \\
\text { reasonable policy } \\
\text { in both an outdoor } \\
\text { and indoor } \\
\text { environment? }(3)\end{array}$ & O & 0 & O & 0 & ○ & 0 & 0 \\
\hline $\begin{array}{l}\text { 76. Are current } \\
\text { regulations } \\
\text { surrounding } \\
\text { entrapment } \\
\text { prevention, } \\
\text { fencing } \\
\text { requirements, and } \\
\text { other similar } \\
\text { barriers effective } \\
\text { at reducing } \\
\text { drowning and } \\
\text { aquatic } \\
\text { injuries/fatalities? } \\
\text { (4) }\end{array}$ & 0 & 0 & 0 & 0 & 0 & 0 & 0 \\
\hline
\end{tabular}




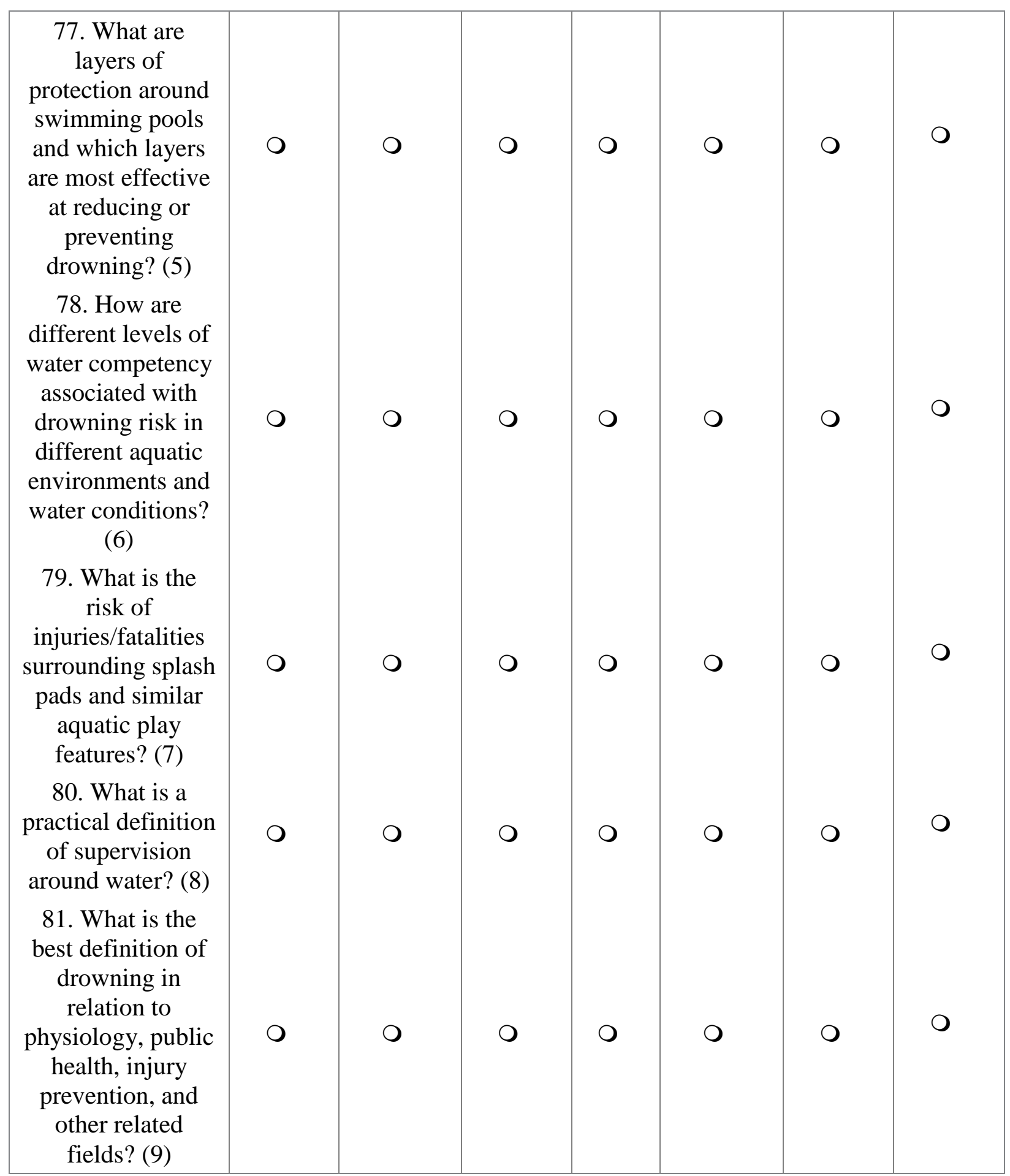




\begin{tabular}{|c|c|c|c|c|c|c|c|}
\hline $\begin{array}{c}\text { 82. What } \\
\text { percentage of the } \\
\text { U.S. population, } \\
\text { by age group, has } \\
\text { a basic } \\
\text { understanding of } \\
\text { water safety AND } \\
\text { water safety } \\
\text { skills? (10) }\end{array}$ & 0 & 0 & 0 & 0 & 0 & 0 & O \\
\hline
\end{tabular}




\begin{tabular}{|c|c|c|c|c|c|c|c|}
\hline & $\begin{array}{c}\text { Not at all } \\
\text { importan } \\
\text { t (1) }\end{array}$ & $\begin{array}{c}\text { Low } \\
\text { importanc } \\
\text { e (2) }\end{array}$ & $\begin{array}{c}\text { Slightly } \\
\text { Importan } \\
\text { t (3) }\end{array}$ & $\begin{array}{c}\text { Neutra } \\
\text { I (4) }\end{array}$ & $\begin{array}{c}\text { Moderatel } \\
y \\
\text { Important } \\
\text { (5) }\end{array}$ & $\begin{array}{c}\text { Very } \\
\text { Importan } \\
\text { t (6) }\end{array}$ & $\begin{array}{c}\text { Extremel } \\
y \\
\text { Importan } \\
t(7)\end{array}$ \\
\hline $\begin{array}{l}\text { 83. What drowning } \\
\text { prevention education } \\
\text { initiatives/strategies } \\
\text { can effectively focus } \\
\text { on diverse } \\
\text { populations? }(1)\end{array}$ & 0 & 0 & 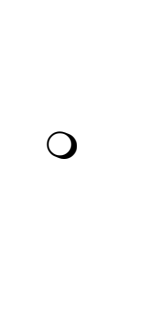 & 0 & 0 & 0 & 0 \\
\hline $\begin{array}{l}\text { 84. What drowning } \\
\text { prevention education } \\
\text { initiatives/strategies } \\
\text { can effectively focus } \\
\text { on adults? (2) }\end{array}$ & 0 & 0 & 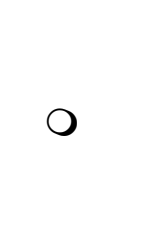 & 0 & 0 & 0 & 0 \\
\hline $\begin{array}{l}\text { 85. How are } \\
\text { neurological } \\
\text { development and risk } \\
\text { taking behavior } \\
\text { factors } \\
\text { addressed/incorporat } \\
\text { ed in drowning } \\
\text { prevention education } \\
\text { for adolescents and } \\
\text { young adults? (3) }\end{array}$ & 0 & 0 & 0 & 0 & 0 & 0 & 0 \\
\hline $\begin{array}{l}\text { 86. What factors } \\
\text { contribute to } \\
\text { minority and low } \\
\text { income children } \\
\text { drowning rates } \\
\text { compared to same } \\
\text { aged peers? (4) }\end{array}$ & 0 & 0 & 0 & 0 & 0 & 0 & 0 \\
\hline $\begin{array}{l}\text { 87. To what extent } \\
\text { do specific cultural } \\
\text { issues impact the } \\
\text { effectiveness of } \\
\text { drowning prevention } \\
\text { education and the use } \\
\text { of safe practices? (5) }\end{array}$ & 0 & 0 & 0 & 0 & 0 & 0 & 0 \\
\hline
\end{tabular}




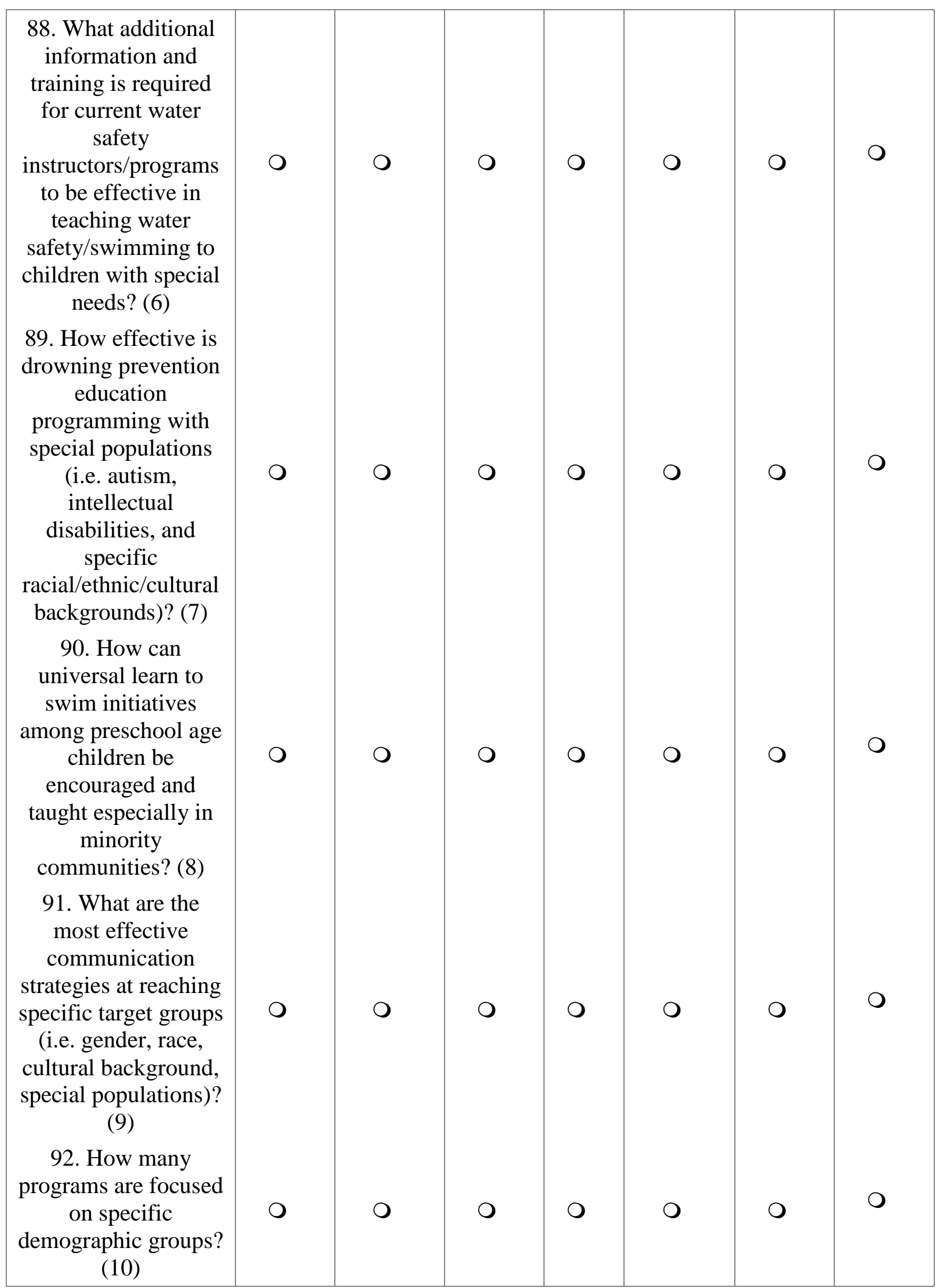




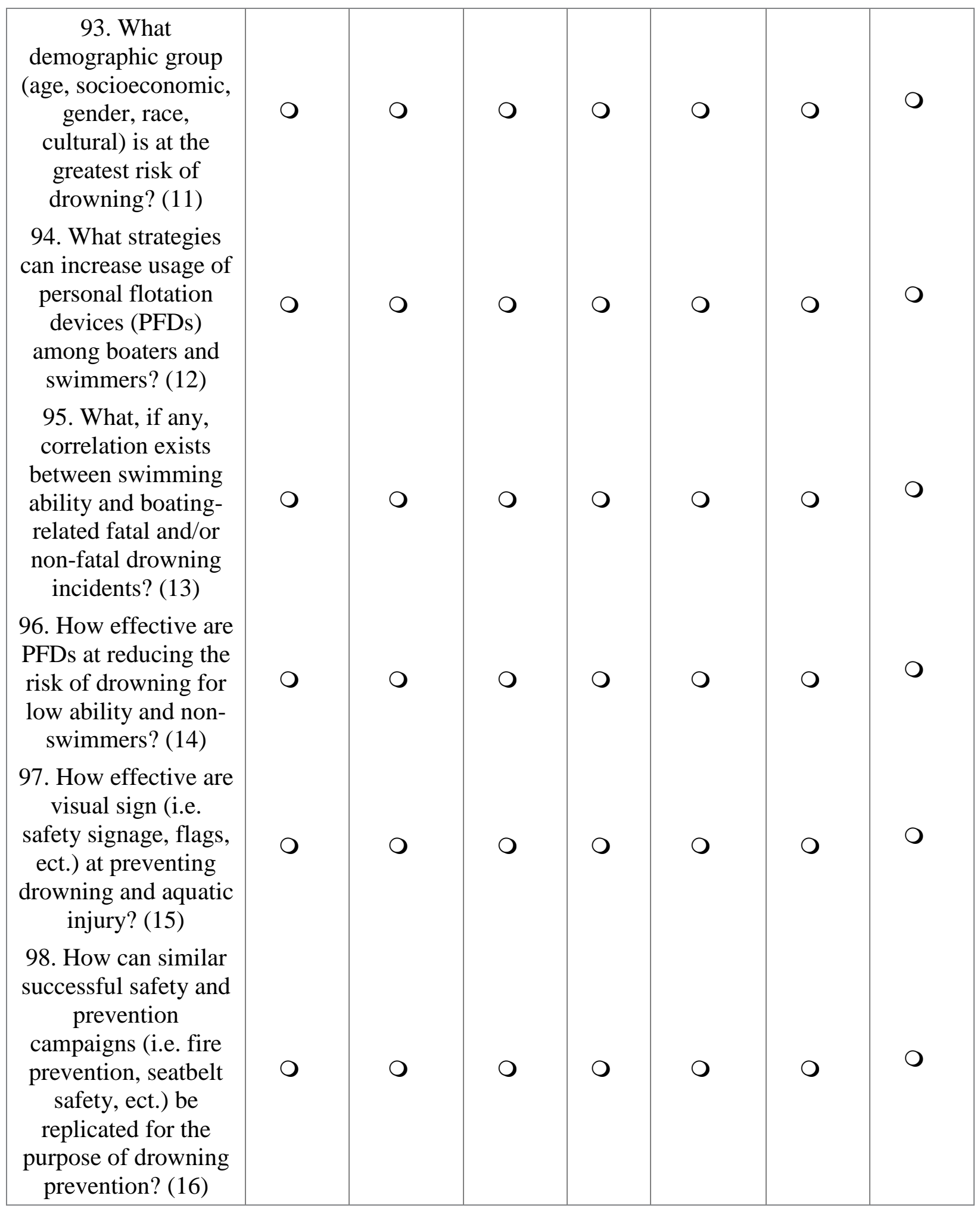




\begin{tabular}{|c|c|c|c|c|c|c|c|}
\hline $\begin{array}{l}\text { 99. What } \\
\text { content/messaging } \\
\text { would have the } \\
\text { greatest impact on } \\
\text { the public at-large } \\
\text { regarding water } \\
\text { safety and reducing } \\
\text { the incidence of } \\
\text { drowning. (17) } \\
\text { 100. How effective is } \\
\text { educating the general } \\
\text { public on drowning } \\
\text { prevention and water } \\
\text { safety through } \\
\text { government agencies } \\
\text { (i.e. CPSC, CDC, } \\
\text { State Health } \\
\text { Departments, ect.) } \\
\text { (18) } \\
\text { 101. Can a national } \\
\text { message surrounding } \\
\text { water safety and } \\
\text { drowning prevention } \\
\text { education be } \\
\text { developed? (19) }\end{array}$ & $O$ & 0 & 0 & 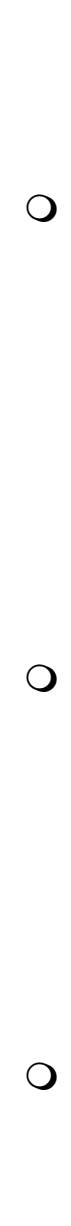 & 0 & 0 & 0 \\
\hline
\end{tabular}




\title{
Appendix I
}

\author{
Round 2 Survey Results
}

\section{A Delphi on Drowning Prevention Education Research Survey Round 2 Results}

\author{
Participant Email -
}

\begin{tabular}{|c|c|c|}
\hline RESEARCH QUESTION & GROUP RATING & YOUR RATING \\
\hline $\begin{array}{l}\text { 1. What protective effects (if } \\
\text { any) against drowning exist } \\
\text { after swim lessons/learning to } \\
\text { swim remain across the } \\
\text { lifespan? }\end{array}$ & $\begin{array}{c}\text { Moderately Important }- \\
\text { Very Important } \\
5.71\end{array}$ & \\
\hline $\begin{array}{l}\text { 2. What role do different } \\
\text { levels of water competence } \\
\text { (a.k.a., swimming skill level) } \\
\text { play in preventing fatal and } \\
\text { non-fatal drownings? }\end{array}$ & $\begin{array}{c}\text { Very Important - } \\
\text { Extremely Important } \\
6.02\end{array}$ & \\
\hline $\begin{array}{l}\text { 3. What are critical skills are } \\
\text { needed for self-rescue? }\end{array}$ & $\begin{array}{c}\text { Moderately Important - } \\
\text { Very Important } \\
5.91\end{array}$ & \\
\hline $\begin{array}{l}\text { 4. What is the best age to } \\
\text { begin children's swim } \\
\text { lessons? }\end{array}$ & $\begin{array}{c}\text { Moderately Important - } \\
\text { Very Important } \\
5.36\end{array}$ & \\
\hline $\begin{array}{l}\text { 5. What is the specific age } \\
\text { (range) when swim lessons } \\
\text { have the most protective } \\
\text { effect against drowning for } \\
\text { children? }\end{array}$ & $\begin{array}{c}\text { Moderately Important - } \\
\text { Very Important } \\
5.59\end{array}$ & \\
\hline $\begin{array}{l}\text { 6. What are the perceived } \\
\text { barriers and facilitators to } \\
\text { learning to swim in the U.S.? }\end{array}$ & $\begin{array}{l}\text { Moderately Important - } \\
\text { Very Important }\end{array}$ & \\
\hline
\end{tabular}




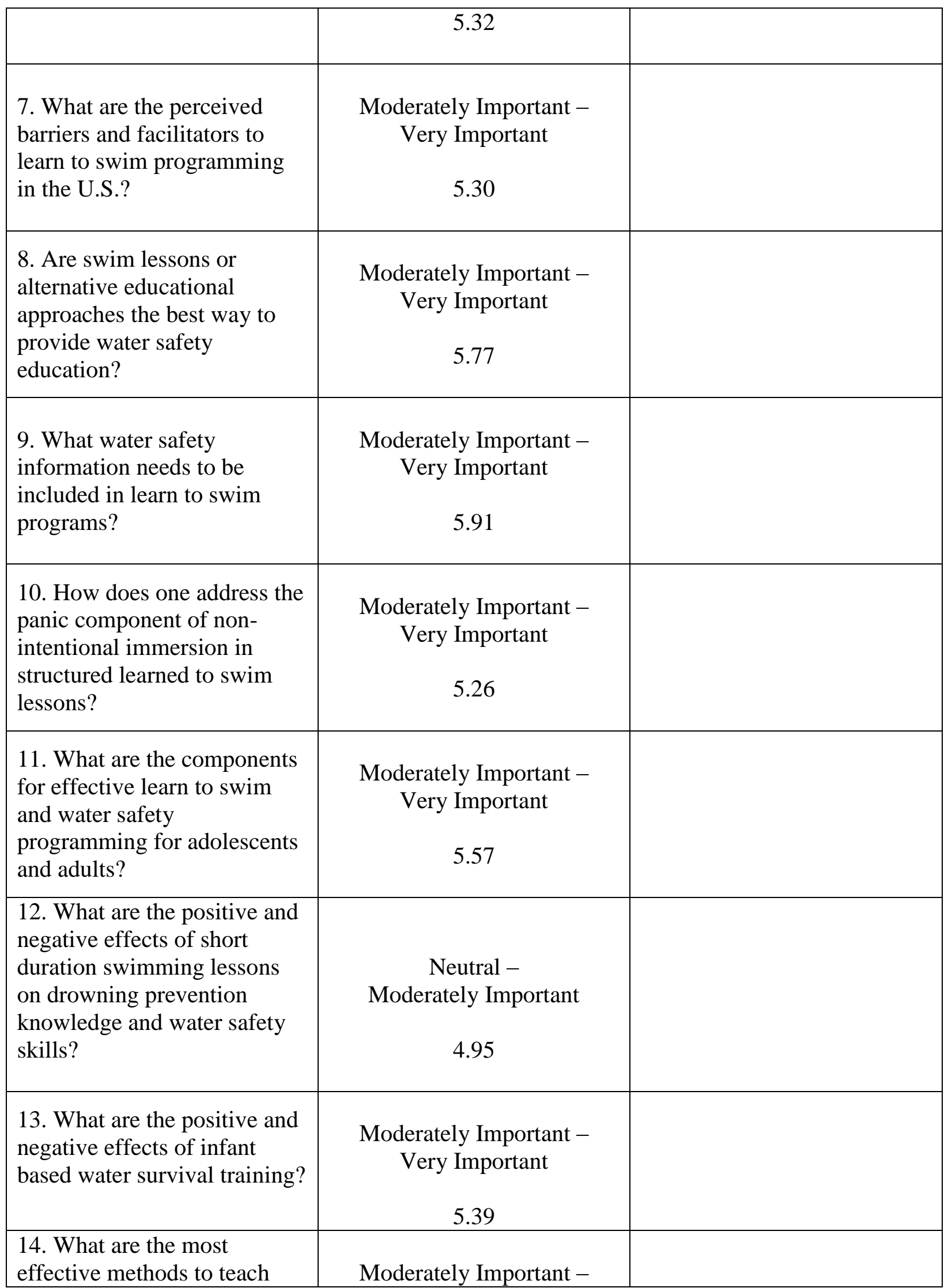




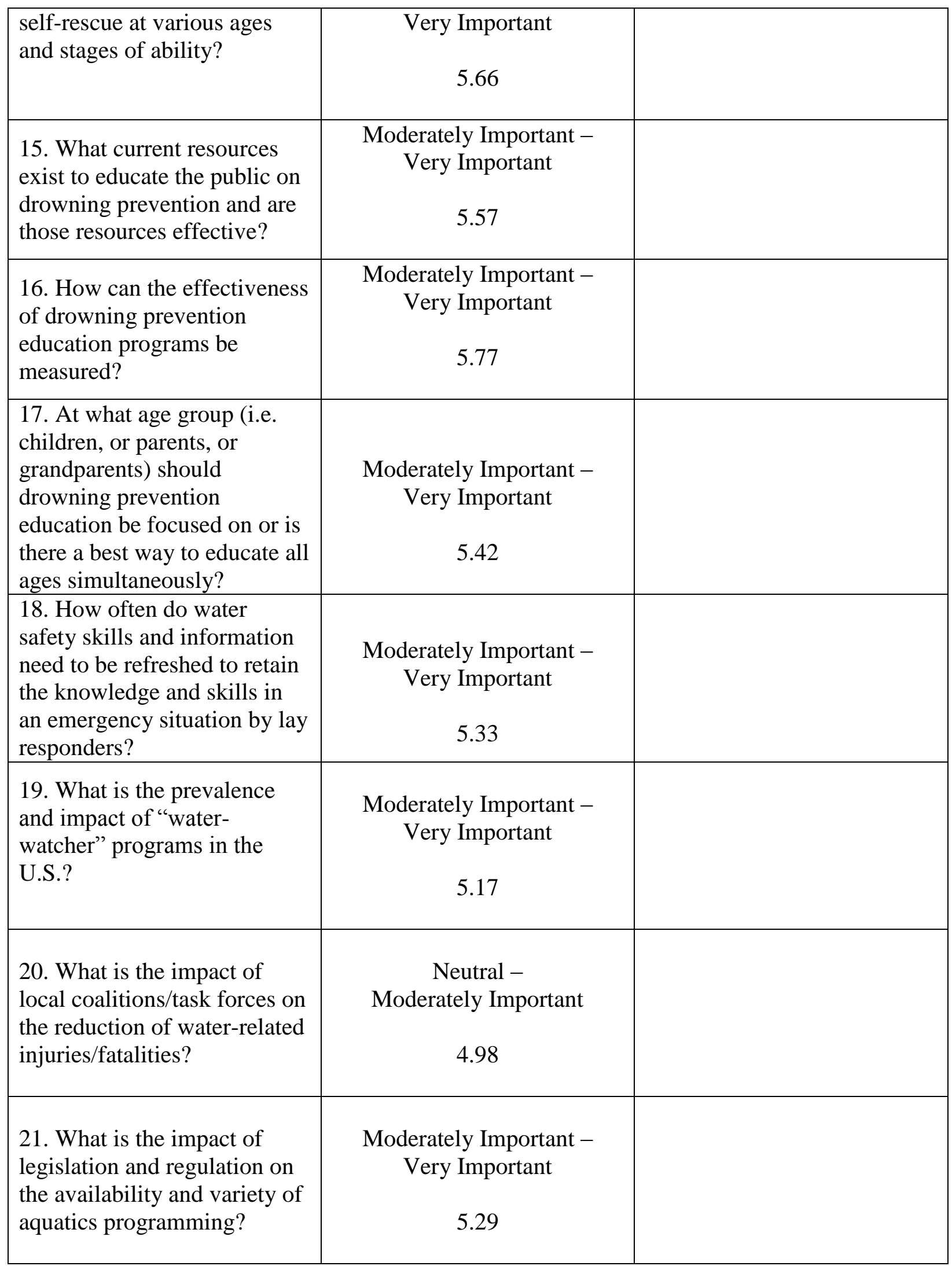




\begin{tabular}{|c|c|c|}
\hline $\begin{array}{l}\text { 22. What strategies can } \\
\text { increase public awareness } \\
\text { around the risk of bathtub } \\
\text { drownings? }\end{array}$ & $\begin{array}{c}\text { Moderately Important - } \\
\text { Very Important } \\
5.17\end{array}$ & \\
\hline $\begin{array}{l}\text { 23. What can be done to } \\
\text { increase public recognition of } \\
\text { drowning as a public health } \\
\text { issue? }\end{array}$ & $\begin{array}{c}\text { Very Important - } \\
\text { Extremely Important } \\
6.21\end{array}$ & \\
\hline $\begin{array}{l}\text { 24. When and where is the } \\
\text { most effective time and place } \\
\text { to provide drowning } \\
\text { prevention/water safety } \\
\text { education to all ages? }\end{array}$ & $\begin{array}{c}\text { Moderately Important - } \\
\text { Very Important } \\
5.78\end{array}$ & \\
\hline $\begin{array}{l}25 . \text { What is the reach and } \\
\text { scope of current drowning } \\
\text { prevention/water safety } \\
\text { education programs in the } \\
\text { U.S.? }\end{array}$ & $\begin{array}{c}\text { Moderately Important - } \\
\text { Very Important } \\
5.55\end{array}$ & \\
\hline $\begin{array}{l}\text { 26. Have environmental, } \\
\text { behavioral, and legislative or } \\
\text { regulatory interventions } \\
\text { reduced fatal/non-fatal } \\
\text { drownings? }\end{array}$ & $\begin{array}{c}\text { Moderately Important - } \\
\text { Very Important } \\
5.43\end{array}$ & \\
\hline $\begin{array}{l}27 . \text { What } \\
\text { programs/initiatives, besides } \\
\text { mandatory requirements and } \\
\text { federal regulations, can be } \\
\text { enacted to reduce drowning } \\
\text { deaths in the U.S.? }\end{array}$ & $\begin{array}{c}\text { Moderately Important - } \\
\text { Very Important } \\
5.80\end{array}$ & \\
\hline $\begin{array}{l}\text { 28. How can the dangers of } \\
\text { "attractive nuisances" be } \\
\text { better articulated? }\end{array}$ & $\begin{array}{c}\text { Neutral - } \\
\text { Moderately Important } \\
4.67\end{array}$ & \\
\hline $\begin{array}{l}29 \text {. How can the accuracy of } \\
\text { current statistics on fatal and }\end{array}$ & $\begin{array}{c}\text { Moderately Important - } \\
\text { Very Important }\end{array}$ & \\
\hline
\end{tabular}




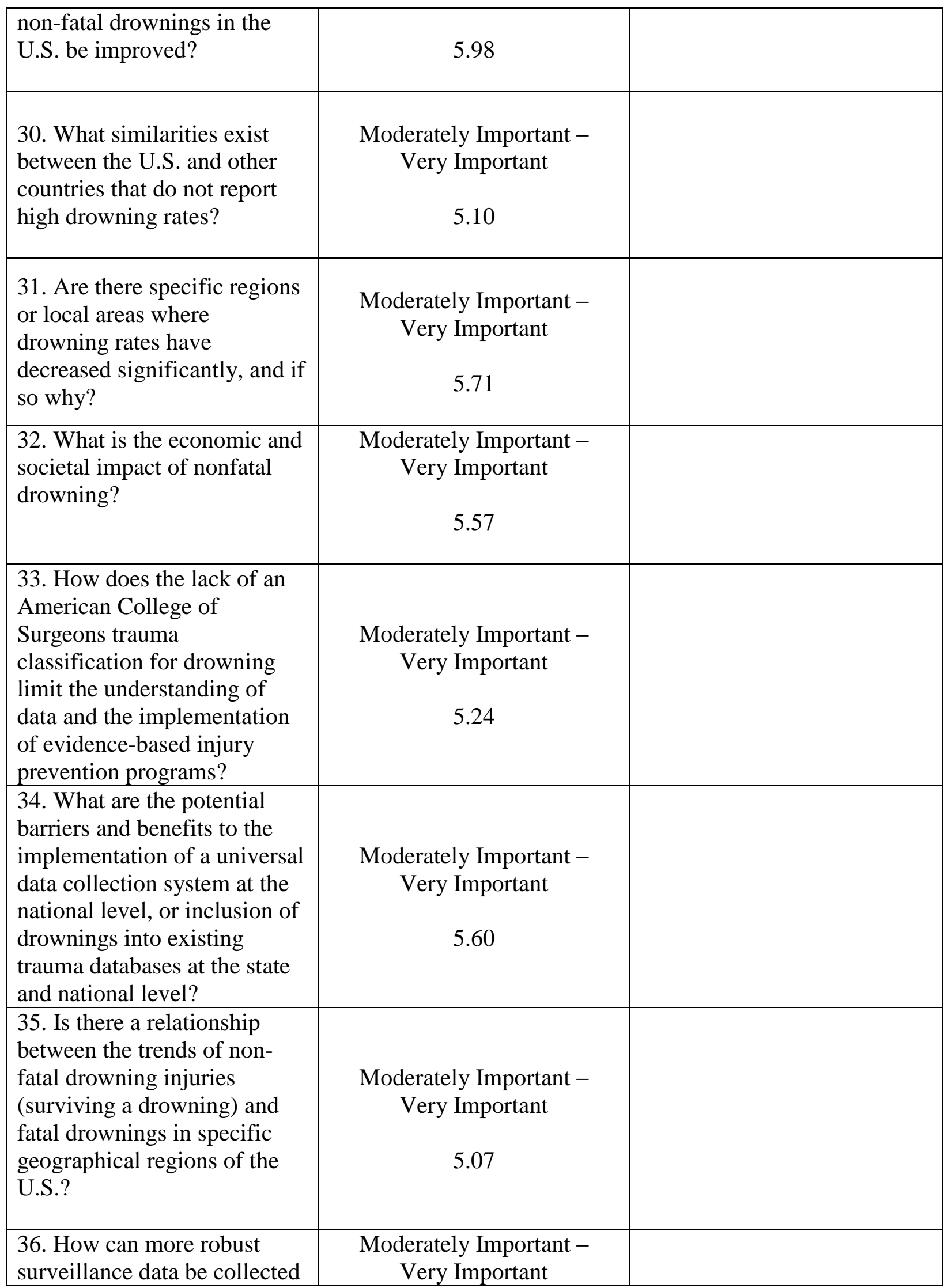




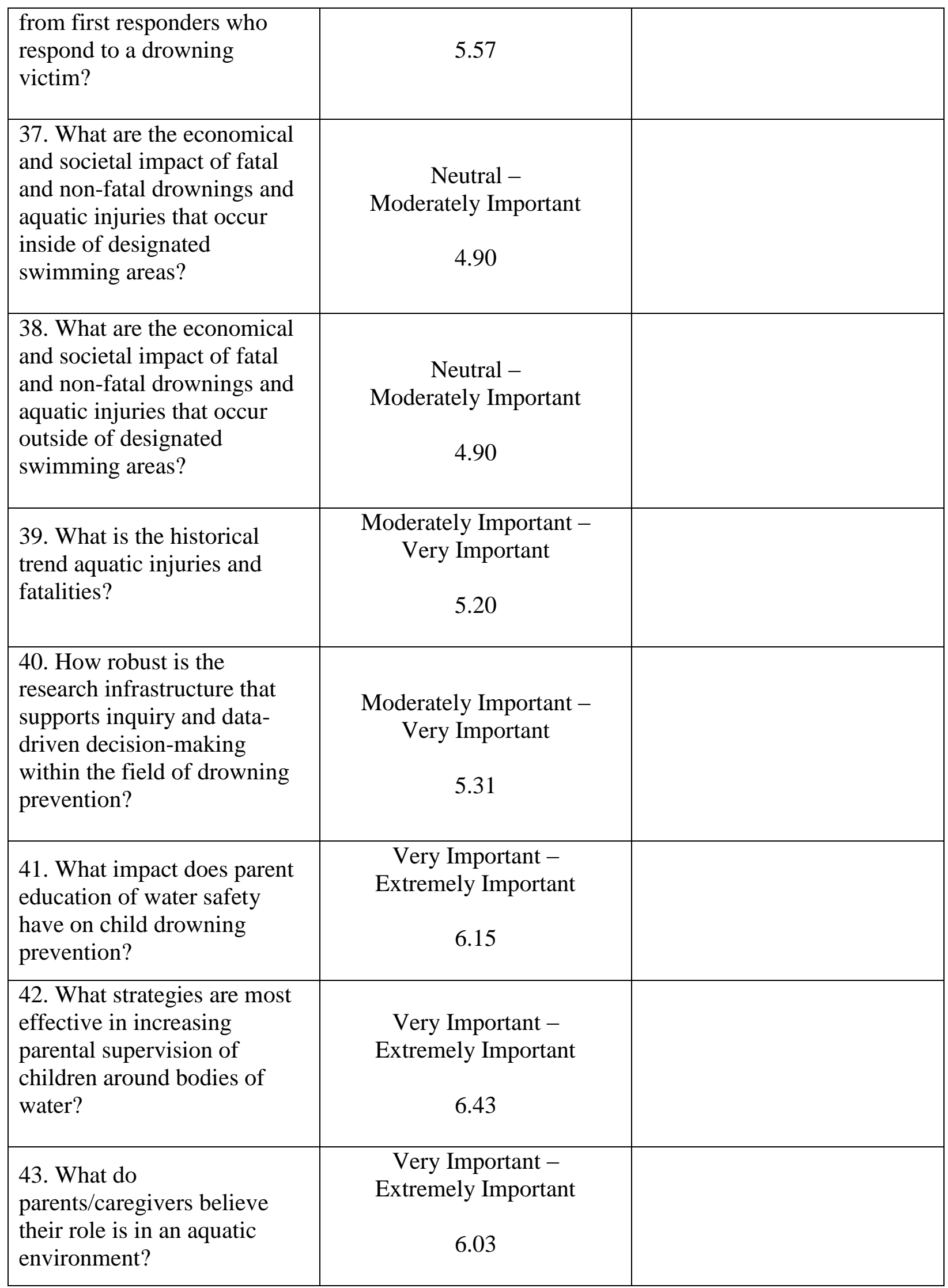




\begin{tabular}{|c|c|}
\hline $\begin{array}{l}\text { 44. What are parent } \\
\text { perceptions of and } \\
\text { motivations for enrolling a } \\
\text { child in swim lessons? }\end{array}$ & $\begin{array}{c}\text { Moderately Important - } \\
\text { Very Important } \\
5.80\end{array}$ \\
\hline $\begin{array}{l}\text { 45. What can be done to } \\
\text { increase parental supervision } \\
\text { when lifeguards are present? }\end{array}$ & $\begin{array}{c}\text { Very Important }- \\
\text { Extremely Important } \\
6.15\end{array}$ \\
\hline $\begin{array}{l}\text { 46. In what was can drowning } \\
\text { prevention/water safety } \\
\text { information be effectively } \\
\text { delivered as part of a } \\
\text { parenting course? }\end{array}$ & $\begin{array}{c}\text { Moderately Important - } \\
\text { Very Important } \\
5.64\end{array}$ \\
\hline $\begin{array}{l}\text { 47. In what ways, if any, does } \\
\text { a parent's residential location } \\
\text { impact their parental } \\
\text { knowledge of water safety? }\end{array}$ & $\begin{array}{c}\text { Moderately Important - } \\
\text { Very Important } \\
5.08\end{array}$ \\
\hline $\begin{array}{l}\text { 48. Are lifeguards and parents } \\
\text { effective at recognizing a } \\
\text { drowning victim and what } \\
\text { can be done to increase } \\
\text { victim recognition? }\end{array}$ & $\begin{array}{c}\text { Very Important }- \\
\text { Extremely Important } \\
6.13\end{array}$ \\
\hline $\begin{array}{l}\text { 49. What protocols exist for } \\
\text { having lifeguards on duty } \\
\text { during educational courses } \\
\text { and events? }\end{array}$ & $\begin{array}{c}\text { Moderately Important - } \\
\text { Very Important } \\
5.60\end{array}$ \\
\hline $\begin{array}{l}50 . \text { What is a safe time } \\
\text { duration of time for } \\
\text { lifeguards to be on-duty? }\end{array}$ & $\begin{array}{c}\text { Moderately Important - } \\
\text { Very Important } \\
5.85\end{array}$ \\
\hline $\begin{array}{l}51 . \text { How many drownings } \\
\text { occur each year at locations } \\
\text { where lifeguards are present? }\end{array}$ & $\begin{array}{c}\text { Moderately Important - } \\
\text { Very Important } \\
5.75\end{array}$ \\
\hline $\begin{array}{l}\text { 52. Is there a significant } \\
\text { difference between drowning } \\
\text { rates when lifeguards are } \\
\text { present? }\end{array}$ & $\begin{array}{c}\text { Very Important - } \\
\text { Extremely Important } \\
6.03\end{array}$ \\
\hline
\end{tabular}




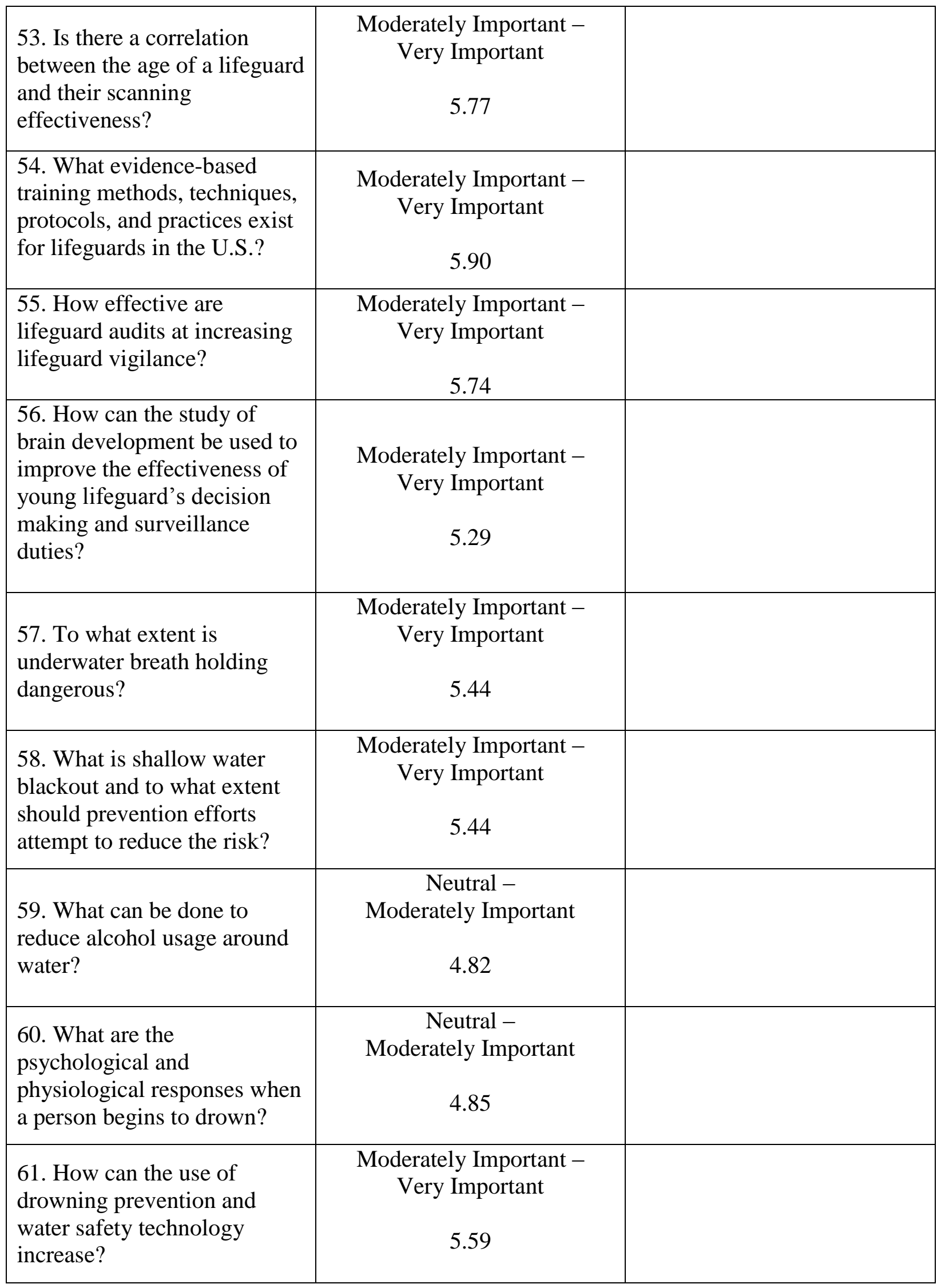




\begin{tabular}{|c|c|c|}
\hline $\begin{array}{l}\text { 62. To what extent are } \\
\text { specific variables (i.e. } \\
\text { supervision, drug and alcohol } \\
\text { use, prior convictions, } \\
\text { conditions of water, } \\
\text { prevention and rescue } \\
\text { training, time child was } \\
\text { missing) associated with } \\
\text { drowning? }\end{array}$ & $\begin{array}{c}\text { Moderately Important - } \\
\text { Very Important } \\
5.58\end{array}$ & \\
\hline $\begin{array}{l}\text { 63. What barriers exist for } \\
\text { drowning prevention and } \\
\text { water safety education in K- } \\
12 \text { schools across the U.S.? }\end{array}$ & $\begin{array}{c}\text { Moderately Important - } \\
\text { Very Important } \\
5.56 \\
\end{array}$ & \\
\hline $\begin{array}{l}\text { 64. What effective } \\
\text { approaches to teaching } \\
\text { drowning prevention and } \\
\text { water safety education in K- } \\
12 \text { schools across the U.S.? }\end{array}$ & $\begin{array}{c}\text { Moderately Important }- \\
\text { Very Important } \\
5.69\end{array}$ & \\
\hline $\begin{array}{l}\text { 65. Is dryland-based water } \\
\text { safety education more or less } \\
\text { effective than in water-based } \\
\text { education? }\end{array}$ & $\begin{array}{c}\text { Neutral - } \\
\text { Moderately Important } \\
4.92\end{array}$ & \\
\hline $\begin{array}{l}\text { 66. What, if any, effect does } \\
\text { including water safety in a K- } \\
12 \text { school's curriculum have } \\
\text { on the reduction of drowning } \\
\text { risk? }\end{array}$ & $\begin{array}{c}\text { Very Important - } \\
\text { Extremely Important } \\
6.00\end{array}$ & \\
\hline $\begin{array}{l}67 . \text { What requirements exist } \\
\text { by state health and physical } \\
\text { education } \\
\text { standards/objectives } \\
\text { regarding water } \\
\text { safety/drowning prevention } \\
\text { education? }\end{array}$ & $\begin{array}{c}\text { Moderately Important }- \\
\text { Very Important } \\
5.51\end{array}$ & \\
\hline $\begin{array}{l}68 . \text { What, if any, benefit } \\
\text { exists to using classroom- } \\
\text { based curriculum as a } \\
\text { prerequisite to swimming } \\
\text { lessons? }\end{array}$ & $\begin{array}{c}\text { Moderately Important - } \\
\text { Very Important } \\
5.15\end{array}$ & \\
\hline
\end{tabular}




\begin{tabular}{|c|c|c|}
\hline $\begin{array}{l}69 . \text { What is the compliance } \\
\text { rate of the Virginia Graeme } \\
\text { Baker Pool \& Spa Safety } \\
\text { Act? }\end{array}$ & $\begin{array}{c}\text { Neutral - } \\
\text { Moderately Important } \\
4.15\end{array}$ & \\
\hline $\begin{array}{l}\text { 70. What is the impact of } \\
\text { litigation on the availability } \\
\text { and variety of aquatics } \\
\text { programming? }\end{array}$ & $\begin{array}{c}\text { Neutral - } \\
\text { Moderately Important } \\
4.85\end{array}$ & \\
\hline $\begin{array}{l}\text { 71. Has there been a } \\
\text { significant difference in the } \\
\text { number of drownings in } \\
\text { California before/after the } \\
\text { passing of the Swimming } \\
\text { Pool Safety Law passed in } \\
1996 \text { ? }\end{array}$ & $\begin{array}{c}\text { Neutral - } \\
\text { Moderately Important } \\
4.56\end{array}$ & \\
\hline $\begin{array}{l}\text { 72. To what extent are } \\
\text { parent/family member } \\
\text { testimonials used in } \\
\text { developing drowning policy } \\
\text { and legislative efforts? }\end{array}$ & $\begin{array}{c}\text { Neutral - } \\
\text { Moderately Important } \\
4.73\end{array}$ & \\
\hline $\begin{array}{l}\text { 73. What are the most } \\
\text { common drowning/accidents } \\
\text { in aquatic environments? }\end{array}$ & $\begin{array}{c}\text { Moderately Important - } \\
\text { Very Important } \\
5.74\end{array}$ & \\
\hline $\begin{array}{l}\text { 74. What aquatic } \\
\text { environments (i.e., pool, spa, } \\
\text { lake, river, ocean) have the } \\
\text { greatest number of aquatic } \\
\text { injuries/fatalities? }\end{array}$ & $\begin{array}{c}\text { Moderately Important - } \\
\text { Very Important } \\
5.69\end{array}$ & \\
\hline $\begin{array}{l}75 . \text { In regards to lightning } \\
\text { what is a reasonable policy in } \\
\text { both an outdoor and indoor } \\
\text { environment? }\end{array}$ & $\begin{array}{c}\text { Neutral - } \\
\text { Moderately Important } \\
4.72\end{array}$ & \\
\hline $\begin{array}{l}\text { 76. Are current regulations } \\
\text { surrounding entrapment } \\
\text { prevention, fencing } \\
\text { requirements, and other } \\
\text { similar barriers effective at } \\
\text { reducing drowning and } \\
\text { aquatic injuries/fatalities? }\end{array}$ & $\begin{array}{c}\text { Moderately Important - } \\
\text { Very Important } \\
5.00\end{array}$ & \\
\hline
\end{tabular}




\begin{tabular}{|c|c|c|}
\hline $\begin{array}{l}\text { 77. What are layers of } \\
\text { protection around swimming } \\
\text { pools and which layers are } \\
\text { most effective at reducing or } \\
\text { preventing drowning? }\end{array}$ & $\begin{array}{c}\text { Moderately Important - } \\
\text { Very Important } \\
5.56\end{array}$ & \\
\hline $\begin{array}{l}\text { 78. How are different levels } \\
\text { of water competency } \\
\text { associated with drowning risk } \\
\text { in different aquatic } \\
\text { environments and water } \\
\text { conditions? }\end{array}$ & $\begin{array}{c}\text { Moderately Important - } \\
\text { Very Important } \\
5.25\end{array}$ & \\
\hline $\begin{array}{l}\text { 79. What is the risk of } \\
\text { injuries/fatalities surrounding } \\
\text { splash pads and similar } \\
\text { aquatic play features? }\end{array}$ & $\begin{array}{c}\text { Neutral - } \\
\text { Moderately Important } \\
4.62\end{array}$ & \\
\hline $\begin{array}{l}80 . \text { What is a practical } \\
\text { definition of supervision } \\
\text { around water? }\end{array}$ & $\begin{array}{c}\text { Moderately Important - } \\
\text { Very Important } \\
5.51\end{array}$ & \\
\hline $\begin{array}{l}\text { 81. What is the best definition } \\
\text { of drowning in relation to } \\
\text { physiology, public health, } \\
\text { injury prevention, and other } \\
\text { related fields? }\end{array}$ & $\begin{array}{c}\text { Moderately Important - } \\
\text { Very Important } \\
5.13\end{array}$ & \\
\hline $\begin{array}{l}\text { 82. What percentage of the } \\
\text { U.S. population, by age } \\
\text { group, has a basic } \\
\text { understanding of water safety } \\
\text { AND water safety skills? }\end{array}$ & $\begin{array}{c}\text { Moderately Important - } \\
\text { Very Important } \\
5.08\end{array}$ & \\
\hline $\begin{array}{l}\text { 83. What drowning } \\
\text { prevention education } \\
\text { initiatives/strategies can } \\
\text { effectively focus on diverse } \\
\text { populations? }\end{array}$ & $\begin{array}{c}\text { Moderately Important - } \\
\text { Very Important } \\
5.75\end{array}$ & \\
\hline $\begin{array}{l}\text { 84. What drowning } \\
\text { prevention education } \\
\text { initiatives/strategies can } \\
\text { effectively focus on adults }\end{array}$ & $\begin{array}{c}\text { Moderately Important - } \\
\text { Very Important } \\
5.41\end{array}$ & \\
\hline
\end{tabular}




\begin{tabular}{|c|c|c|}
\hline $\begin{array}{l}85 . \text { How are neurological } \\
\text { development and risk taking } \\
\text { behavior factors } \\
\text { addressed/incorporated in } \\
\text { drowning prevention } \\
\text { education for adolescents and } \\
\text { young adults? }\end{array}$ & $\begin{array}{c}\text { Moderately Important - } \\
\text { Very Important } \\
5.13\end{array}$ & \\
\hline $\begin{array}{l}\text { 86. What factors contribute to } \\
\text { minority and low income } \\
\text { children drowning rates } \\
\text { compared to same aged } \\
\text { peers? }\end{array}$ & $\begin{array}{c}\text { Moderately Important - } \\
\text { Very Important } \\
5.78\end{array}$ & \\
\hline $\begin{array}{l}\text { 87. To what extent do } \\
\text { specific cultural issues impact } \\
\text { the effectiveness of drowning } \\
\text { prevention education and the } \\
\text { use of safe practices? }\end{array}$ & $\begin{array}{c}\text { Moderately Important - } \\
\text { Very Important } \\
5.70\end{array}$ & \\
\hline $\begin{array}{l}88 \text {. What additional } \\
\text { information and training is } \\
\text { required for current water } \\
\text { safety instructors/programs to } \\
\text { be effective in teaching water } \\
\text { safety/swimming to children } \\
\text { with special needs? }\end{array}$ & $\begin{array}{c}\text { Moderately Important - } \\
\text { Very Important } \\
5.41\end{array}$ & \\
\hline $\begin{array}{l}89 . \text { How effective is } \\
\text { drowning prevention } \\
\text { education programming with } \\
\text { special populations (i.e. } \\
\text { autism, intellectual } \\
\text { disabilities, and specific } \\
\text { racial/ethnic/cultural } \\
\text { backgrounds)? }\end{array}$ & $\begin{array}{c}\text { Moderately Important - } \\
\text { Very Important } \\
5.73\end{array}$ & \\
\hline $\begin{array}{l}\text { 90. How can universal learn } \\
\text { to swim initiatives among } \\
\text { preschool age children be } \\
\text { encouraged and taught } \\
\text { especially in minority } \\
\text { communities? }\end{array}$ & $\begin{array}{c}\text { Moderately Important - } \\
\text { Very Important } \\
5.54\end{array}$ & \\
\hline
\end{tabular}




\begin{tabular}{|c|c|c|}
\hline $\begin{array}{l}\text { 91. What are the most } \\
\text { effective communication } \\
\text { strategies at reaching specific } \\
\text { target groups (i.e. gender, } \\
\text { race, cultural background, } \\
\text { special populations)? }\end{array}$ & $\begin{array}{c}\text { Moderately Important - } \\
\text { Very Important } \\
5.68\end{array}$ & \\
\hline $\begin{array}{l}\text { 92. How many programs are } \\
\text { focused on specific } \\
\text { demographic groups? }\end{array}$ & $\begin{array}{c}\text { Neutral - } \\
\text { Moderately Important } \\
4.38\end{array}$ & \\
\hline $\begin{array}{l}\text { 93. What demographic group } \\
\text { (age, socioeconomic, gender, } \\
\text { race, cultural) is at the } \\
\text { greatest risk of drowning? }\end{array}$ & $\begin{array}{c}\text { Moderately Important - } \\
\text { Very Important } \\
5.36\end{array}$ & \\
\hline $\begin{array}{l}\text { 94. What strategies can } \\
\text { increase usage of personal } \\
\text { flotation devices (PFDs) } \\
\text { among boaters and } \\
\text { swimmers? }\end{array}$ & $\begin{array}{c}\text { Moderately Important - } \\
\text { Very Important } \\
5.79\end{array}$ & \\
\hline $\begin{array}{l}\text { 95. What, if any, correlation } \\
\text { exists between swimming } \\
\text { ability and boating-related } \\
\text { fatal and/or non-fatal } \\
\text { drowning incidents? }\end{array}$ & $\begin{array}{c}\text { Moderately Important - } \\
\text { Very Important } \\
5.03\end{array}$ & \\
\hline $\begin{array}{l}\text { 96. How effective are PFDs } \\
\text { at reducing the risk of } \\
\text { drowning for low ability and } \\
\text { non-swimmers? }\end{array}$ & $\begin{array}{l}\text { Moderately Important - } \\
\text { Very Important } \\
5.80\end{array}$ & \\
\hline $\begin{array}{l}\text { 97. How effective are visual } \\
\text { sign (i.e. safety signage, } \\
\text { flags, ect.) at preventing } \\
\text { drowning and aquatic injury? }\end{array}$ & $\begin{array}{c}\text { Moderately Important - } \\
\text { Very Important } \\
5.43\end{array}$ & \\
\hline $\begin{array}{l}\text { 98. How can similar } \\
\text { successful safety and } \\
\text { prevention campaigns (i.e. } \\
\text { fire prevention, seatbelt } \\
\text { safety, ect.) be replicated for } \\
\text { the purpose of drowning } \\
\text { prevention? }\end{array}$ & $\begin{array}{c}\text { Moderately Important - } \\
\text { Very Important } \\
5.74\end{array}$ & \\
\hline
\end{tabular}




\begin{tabular}{|l|c|c|}
\hline $\begin{array}{l}\text { 99. What content/messaging } \\
\text { would have the greatest } \\
\text { impact on the public at-large } \\
\text { regarding water safety and } \\
\text { reducing the incidence of } \\
\text { drowning? }\end{array}$ & $\begin{array}{c}\text { Moderately Important - } \\
\text { Very Important }\end{array}$ & \\
\hline $\begin{array}{l}\text { 100. How effective is } \\
\text { educating the general public } \\
\text { on drowning prevention and } \\
\text { water safety through } \\
\text { government agencies (i.e. } \\
\text { CPSC, CDC, State Health } \\
\text { Departments, ect.)? }\end{array}$ & Moderately Important - \\
Very Important & 5.55 & \\
\hline $\begin{array}{l}\text { 101. Can a national message } \\
\text { surrounding water safety and } \\
\text { drowning prevention } \\
\text { education be developed? }\end{array}$ & $\begin{array}{l}\text { Moderately Important - } \\
\text { Very Important }\end{array}$ & \\
\hline
\end{tabular}




\section{Appendix J}

\section{Consensus Building Round 3 Survey}

Email Please enter the e-mail address in-which you are receiving communication regarding this study:

PURPOSE: The purpose of this study is to identify and rate the importance of potential outstanding research questions surrounding drowning prevention education in the United States.

DIRECTIONS: You will now be presented with the same list of developed research questions from the previous round of surveying. Any question that received a mean rating of 6 ("Very Important") or higher in the previous round of surveying has been removed. There are now 92 questions. Each question's mean score from the previous round has been added under the question text. Please rate each question independently from other questions. **Please note that Mac users using Safari to take the survey have experienced technical errors. If you experience any technical errors please try using another browser to complete the survey. Please use the buttons on the bottom of each page to navigate through the survey.

DIRECTIONS: Please rate the following items on level of importance. Your rating should reflect your personal opinion on the importance of each question being studied.

PROMPT: "How important is it that we answer each particular question?" 


\begin{tabular}{|c|c|c|c|c|c|c|c|}
\hline & $\begin{array}{c}\text { Not at all } \\
\text { Important } \\
1(1)\end{array}$ & $\begin{array}{c}\text { Low } \\
\text { Importance } \\
2 \text { (9) }\end{array}$ & $\begin{array}{l}\text { Slightly } \\
\text { Important } \\
3(10)\end{array}$ & $\begin{array}{c}\text { Neutral } \\
4 \text { (3) }\end{array}$ & $\begin{array}{l}\text { Moderately } \\
\text { Important } \\
5 \text { (4) }\end{array}$ & $\begin{array}{c}\text { Very } \\
\text { Important } \\
6(5)\end{array}$ & $\begin{array}{c}\text { Extremely } \\
\text { Important } \\
7 \text { (6) }\end{array}$ \\
\hline $\begin{array}{c}\text { 1. What } \\
\text { protective } \\
\text { effects (if any) } \\
\text { against } \\
\text { drowning exist } \\
\text { across the } \\
\text { lifespan after } \\
\text { swim } \\
\text { lessons/learning } \\
\text { to swim? (1) }\end{array}$ & $\bigcirc$ & 0 & 0 & 0 & 0 & 0 & 0 \\
\hline $\begin{array}{l}\text { 2. What are } \\
\text { critical skills } \\
\text { are needed for } \\
\text { self-rescue? } \\
\text { (19) }\end{array}$ & 0 & 0 & 0 & 0 & 0 & 0 & 0 \\
\hline $\begin{array}{l}\text { 3. What is the } \\
\text { best age to } \\
\text { begin children's } \\
\text { swim lessons? } \\
\text { (4) }\end{array}$ & 0 & 0 & 0 & 0 & 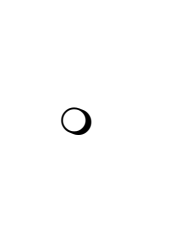 & 0 & 0 \\
\hline $\begin{array}{l}\text { 4. What is the } \\
\text { specific age } \\
\text { (range) when } \\
\text { swim lessons } \\
\text { have the most } \\
\text { protective } \\
\text { effect against } \\
\text { drowning for } \\
\text { children? (5) }\end{array}$ & 0 & 0 & 0 & 0 & 0 & 0 & 0 \\
\hline $\begin{array}{l}\text { 5. What are the } \\
\text { perceived } \\
\text { barriers and } \\
\text { facilitators to } \\
\text { learning to } \\
\text { swim in the } \\
\text { U.S.? (6) }\end{array}$ & 0 & 0 & 0 & 0 & 0 & 0 & 0 \\
\hline
\end{tabular}




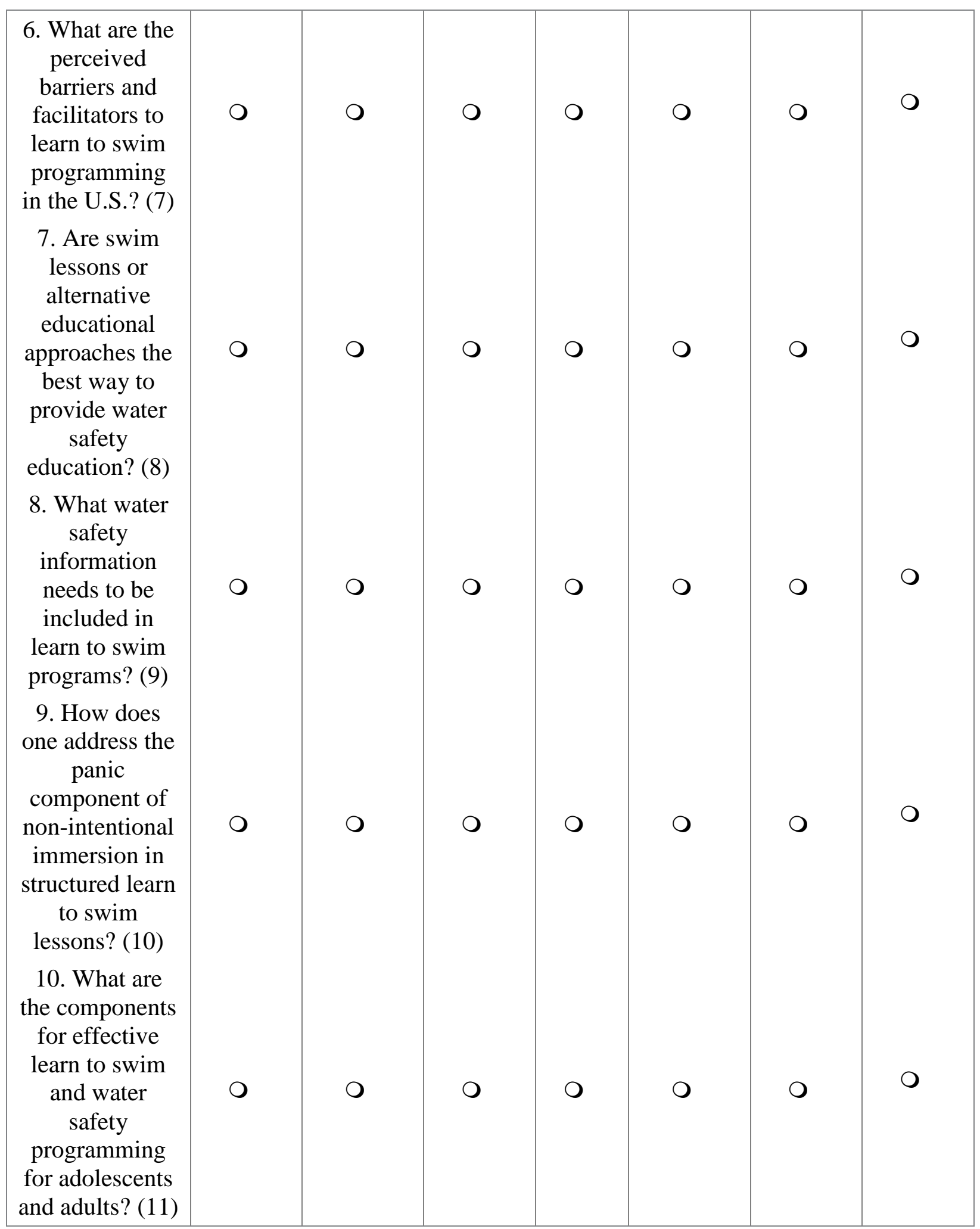




\begin{tabular}{|c|c|c|c|c|c|c|c|}
\hline $\begin{array}{l}\text { 11. What are } \\
\text { the positive and } \\
\text { negative effects } \\
\text { of short } \\
\text { duration } \\
\text { swimming } \\
\text { lessons on } \\
\text { drowning } \\
\text { prevention } \\
\text { knowledge and } \\
\text { water safety } \\
\text { skills? (12) }\end{array}$ & $\mathrm{O}$ & 0 & 0 & 0 & 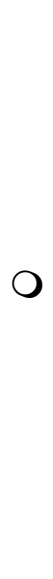 & 0 & O \\
\hline $\begin{array}{l}\text { 12. What are } \\
\text { the positive and } \\
\text { negative effects } \\
\text { of infant based } \\
\text { water survival } \\
\text { training? (13) }\end{array}$ & $\mathrm{O}$ & 0 & 0 & 0 & 0 & 0 & O \\
\hline $\begin{array}{l}\text { 13. What are } \\
\text { the most } \\
\text { effective } \\
\text { methods to } \\
\text { teach self- } \\
\text { rescue at } \\
\text { various ages } \\
\text { and stages of } \\
\text { ability? (14) }\end{array}$ & O & $\mathrm{O}$ & 0 & 0 & $\mathrm{O}$ & O & 0 \\
\hline
\end{tabular}




\begin{tabular}{|c|c|c|c|c|c|c|c|}
\hline & $\begin{array}{c}\text { Not at all } \\
\text { importan } \\
\text { t } 1 \text { (1) }\end{array}$ & $\begin{array}{c}\text { Low } \\
\text { importanc } \\
\text { e } 2(2)\end{array}$ & $\begin{array}{l}\text { Slightly } \\
\text { Importan } \\
\text { t } 3 \text { (3) }\end{array}$ & $\begin{array}{l}\text { Neutra } \\
\text { I } 4 \text { (4) }\end{array}$ & $\begin{array}{c}\text { Moderatel } \\
y \\
\text { Important } \\
5(5)\end{array}$ & $\begin{array}{c}\text { Very } \\
\text { Importan } \\
\text { t } 6(6)\end{array}$ & $\begin{array}{c}\text { Extremely } \\
\text { Importan } \\
\text { t } 7 \text { (7) }\end{array}$ \\
\hline $\begin{array}{l}\text { 14. What current } \\
\text { resources exist to } \\
\text { educate the } \\
\text { public on } \\
\text { drowning } \\
\text { prevention and } \\
\text { are those } \\
\text { resources } \\
\text { effective? (1) }\end{array}$ & 0 & 0 & 0 & 0 & 0 & 0 & 0 \\
\hline $\begin{array}{l}\text { 15. How can the } \\
\text { effectiveness of } \\
\text { drowning } \\
\text { prevention } \\
\text { education } \\
\text { programs be } \\
\text { measured? (2) }\end{array}$ & 0 & 0 & 0 & 0 & 0 & 0 & 0 \\
\hline $\begin{array}{l}\text { 16. At what age } \\
\text { group (i.e. } \\
\text { children, or } \\
\text { parents, or } \\
\text { grandparents) } \\
\text { should drowning } \\
\text { prevention } \\
\text { education be } \\
\text { focused on or is } \\
\text { there a best way } \\
\text { to educate all } \\
\text { ages } \\
\text { simultaneously? } \\
\text { (3) }\end{array}$ & 0 & 0 & 0 & 0 & 0 & 0 & 0 \\
\hline $\begin{array}{l}\text { 17. How often do } \\
\text { water safety } \\
\text { skills and } \\
\text { information need } \\
\text { to be refreshed to } \\
\text { retain the } \\
\text { knowledge and } \\
\text { skills in an } \\
\text { emergency } \\
\text { situation by lay } \\
\text { responders? (4) }\end{array}$ & 0 & 0 & 0 & 0 & 0 & 0 & 0 \\
\hline
\end{tabular}




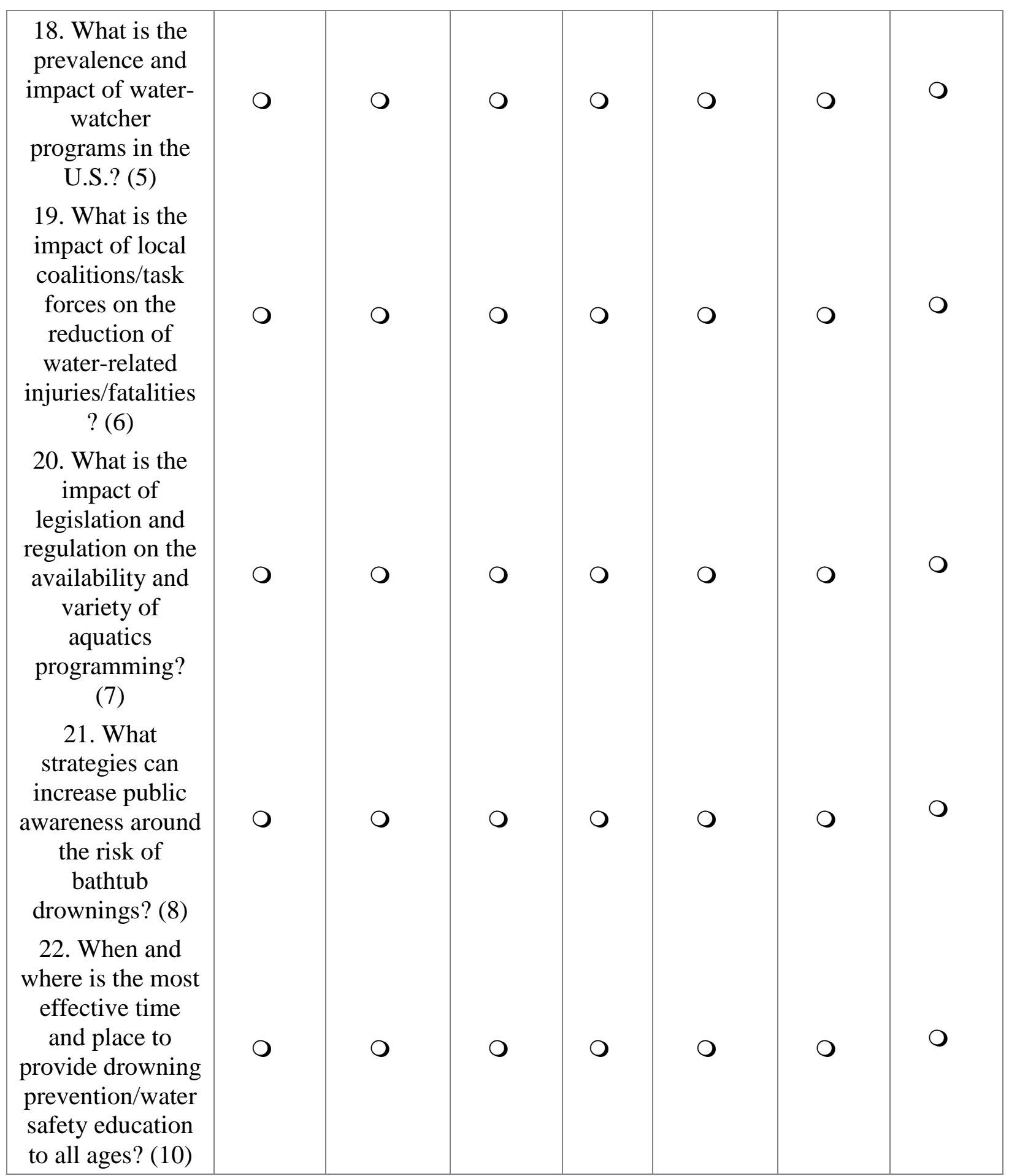




\begin{tabular}{|c|c|c|c|c|c|c|c|}
\hline $\begin{array}{l}\text { 23. What is the } \\
\text { reach and scope } \\
\text { of current } \\
\text { drowning } \\
\text { prevention/water } \\
\text { safety education } \\
\text { programs in the } \\
\text { U.S.? (11) }\end{array}$ & 0 & 0 & 0 & 0 & 0 & 0 & 0 \\
\hline
\end{tabular}




\begin{tabular}{|c|c|c|c|c|c|c|c|}
\hline & $\begin{array}{l}\text { Not at all } \\
\text { importan } \\
\text { t } 1 \text { (1) }\end{array}$ & $\begin{array}{c}\text { Low } \\
\text { importanc } \\
\text { e } 2(2)\end{array}$ & $\begin{array}{l}\text { Slightly } \\
\text { Importan } \\
\text { t } 3 \text { (3) }\end{array}$ & $\begin{array}{l}\text { Neutra } \\
\text { I } 4 \text { (4) }\end{array}$ & $\begin{array}{c}\text { Moderatel } \\
\text { y } \\
\text { Important } \\
5(5)\end{array}$ & $\begin{array}{c}\text { Very } \\
\text { Importan } \\
\text { t } 6(6)\end{array}$ & $\begin{array}{c}\text { Extremel } \\
y \\
\text { Importan } \\
\text { t } 7 \text { (7) }\end{array}$ \\
\hline $\begin{array}{l}\text { 24. Have } \\
\text { environmental, } \\
\text { behavioral, and } \\
\text { legislative or } \\
\text { regulatory } \\
\text { interventions } \\
\text { reduced fatal/non- } \\
\text { fatal drownings? } \\
\text { (1) } \\
\text { 25. What } \\
\text { programs/initiative } \\
\text { s, besides } \\
\text { mandatory } \\
\text { requirements and } \\
\text { federal regulations, } \\
\text { can be enacted to } \\
\text { reduce drowning } \\
\text { deaths in the U.S.? } \\
\text { (2) } \\
\text { 26. How can the } \\
\text { dangers of } \\
\text { "attractive } \\
\text { nuisances" be } \\
\text { that do not report } \\
\text { high drowning } \\
\text { rates? (5) } \\
\text { and otticulated? } \\
\text { (3) } \\
\text { 27. How can the } \\
\text { accuracy of current } \\
\text { statistics on fatal } \\
\text { and non-fatal } \\
\text { drownings in the } \\
\text { U.S. be improved? } \\
\text { (4) } \\
\text { similarities exist } \\
\text { andween the U.S. } \\
\text { ather countries }\end{array}$ & 0 & 0 & 0 & 0 & 0 & 0 & 0 \\
\hline
\end{tabular}




\begin{tabular}{|c|c|c|c|c|c|c|c|}
\hline $\begin{array}{l}\text { 29. Are there } \\
\text { specific regions or } \\
\text { local areas where } \\
\text { drowning rates } \\
\text { have decreased } \\
\text { significantly, and if } \\
\text { so why? (6) } \\
\text { 30. What is the } \\
\text { economic and } \\
\text { societal impact of } \\
\text { nonfatal drowning? } \\
\text { (7) } \\
\text { 31. How does the } \\
\text { lack of an } \\
\text { American College } \\
\text { of Surgeons trauma } \\
\text { classification for } \\
\text { drowning limit the } \\
\text { understanding of } \\
\text { data and the } \\
\text { implementation of } \\
\text { evidence-based } \\
\text { injury prevention } \\
\text { programs? ( } 8 \text { ) } \\
\text { 32. What are the } \\
\text { potential barriers } \\
\text { and benefits to the } \\
\text { implementation of } \\
\text { a universal data } \\
\text { collection system at } \\
\text { the national level, } \\
\text { or inclusion of } \\
\text { drownings into } \\
\text { existing trauma } \\
\text { databases at the } \\
\text { state and national } \\
\text { level? (9) }\end{array}$ & 0 & 0 & 0 & 0 & 0 & 0 & 0 \\
\hline
\end{tabular}




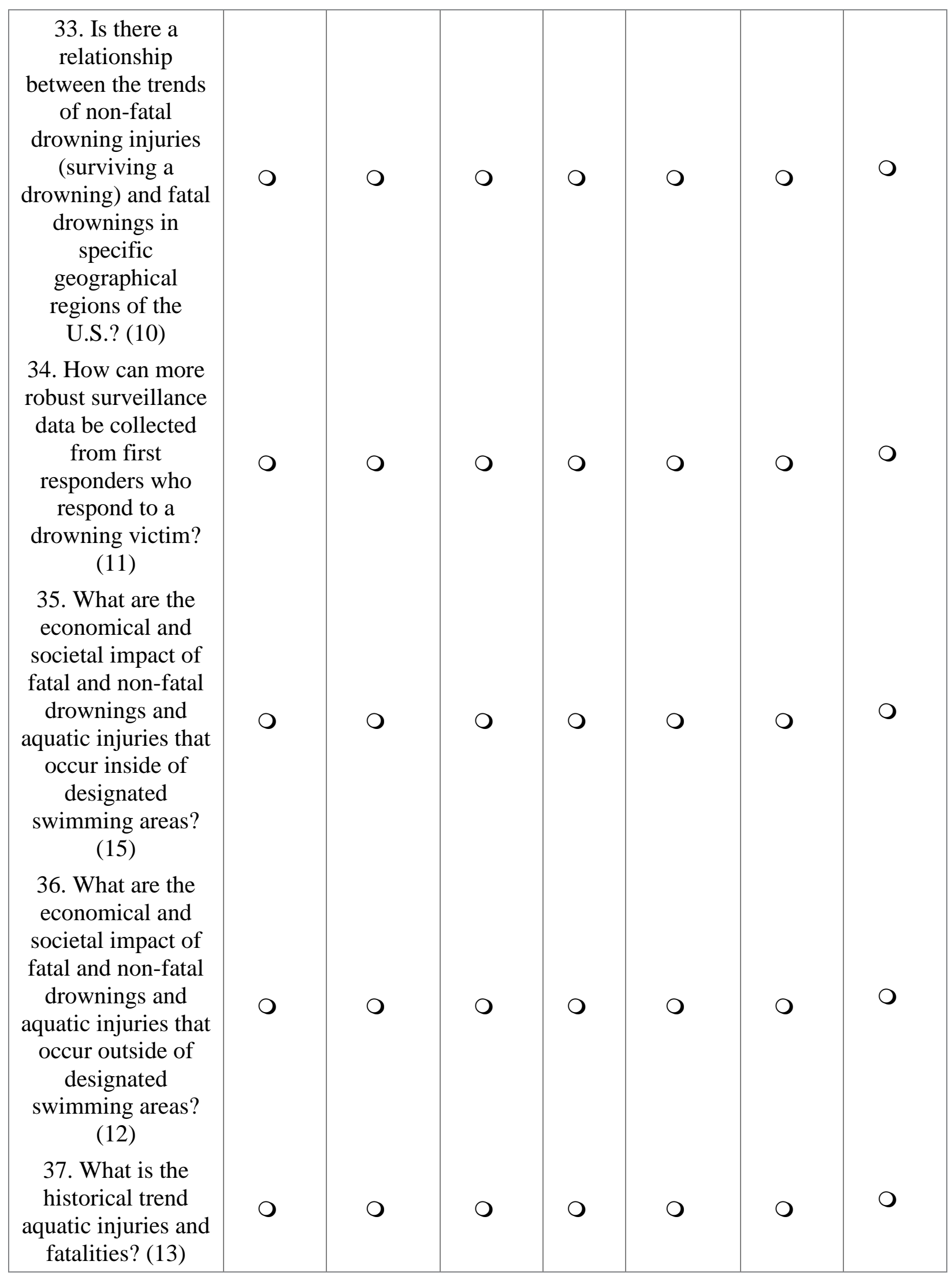




\begin{tabular}{|c|c|c|c|c|c|c|c|}
\hline $\begin{array}{l}\text { 38. How robust is } \\
\text { the research } \\
\text { infrastructure that } \\
\text { supports inquiry } \\
\text { and data-driven } \\
\text { decision-making } \\
\text { within the field of } \\
\text { drowning } \\
\text { prevention? (14) }\end{array}$ & 0 & 0 & 0 & 0 & 0 & 0 & 0 \\
\hline
\end{tabular}




\begin{tabular}{|c|c|c|c|c|c|c|c|}
\hline & $\begin{array}{c}\text { Not at all } \\
\text { important } \\
1(1)\end{array}$ & $\begin{array}{c}\text { Low } \\
\text { importance } \\
2(2)\end{array}$ & $\begin{array}{c}\text { Slightly } \\
\text { Important } \\
3 \text { (3) }\end{array}$ & $\begin{array}{c}\text { Neutral } \\
4(4)\end{array}$ & $\begin{array}{l}\text { Moderately } \\
\text { Important } \\
5 \text { (5) }\end{array}$ & $\begin{array}{c}\text { Very } \\
\text { Important } \\
6(6)\end{array}$ & $\begin{array}{c}\text { Extremely } \\
\text { Important } \\
7 \text { (7) }\end{array}$ \\
\hline $\begin{array}{l}\text { 39. What are } \\
\text { parent } \\
\text { perceptions of } \\
\text { and motivations } \\
\text { for enrolling a } \\
\text { child in swim } \\
\text { lessons? (4) }\end{array}$ & 0 & 0 & 0 & 0 & 0 & 0 & 0 \\
\hline $\begin{array}{l}\text { 40. In what was } \\
\text { can drowning } \\
\text { prevention/water } \\
\text { safety } \\
\text { information be } \\
\text { effectively } \\
\text { delivered as part } \\
\text { of a parenting } \\
\text { course? }(6)\end{array}$ & 0 & 0 & 0 & 0 & 0 & 0 & 0 \\
\hline $\begin{array}{l}\text { 41. In what } \\
\text { ways, if any, } \\
\text { does a parent's } \\
\text { residential } \\
\text { location impact } \\
\text { their parental } \\
\text { knowledge of } \\
\text { water safety. (7) }\end{array}$ & 0 & 0 & 0 & 0 & 0 & 0 & 0 \\
\hline $\begin{array}{l}\text { 42. What } \\
\text { protocols exist } \\
\text { for having } \\
\text { lifeguards on } \\
\text { duty during } \\
\text { educational } \\
\text { courses and } \\
\text { events? (9) }\end{array}$ & 0 & 0 & 0 & 0 & 0 & 0 & 0 \\
\hline $\begin{array}{l}\text { 43. What is a } \\
\text { safe time } \\
\text { duration of time } \\
\text { for lifeguards to } \\
\text { be on-duty? (10) }\end{array}$ & 0 & 0 & 0 & 0 & 0 & 0 & 0 \\
\hline
\end{tabular}




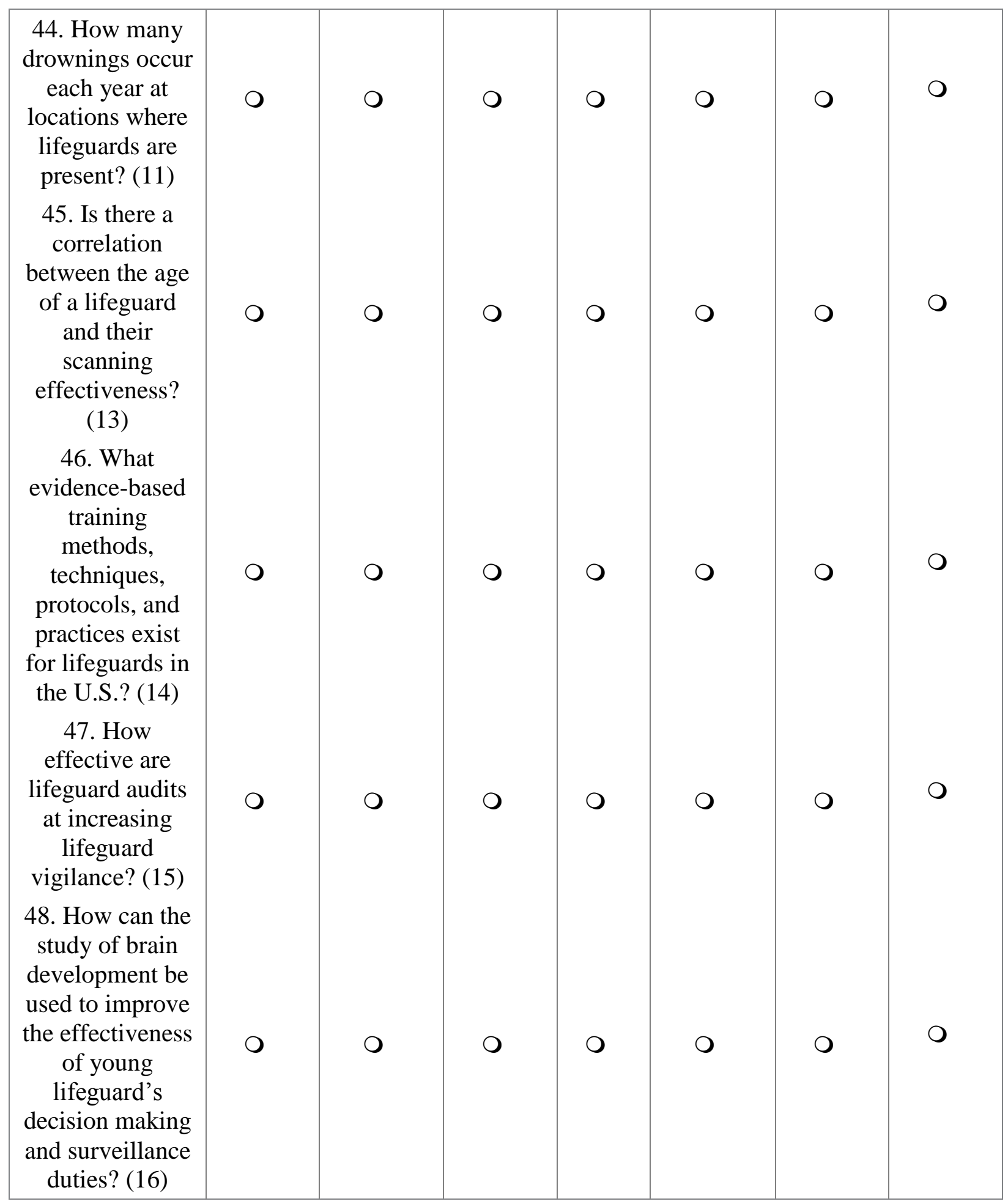




\begin{tabular}{|c|c|c|c|c|c|c|c|}
\hline & $\begin{array}{l}\text { Not at all } \\
\text { importan } \\
\text { t } 1 \text { (1) }\end{array}$ & $\begin{array}{l}\text { Low } \\
\text { importanc } \\
\text { e } 2 \text { (2) }\end{array}$ & $\begin{array}{l}\text { Slightly } \\
\text { Importan } \\
\text { t } 3 \text { (3) }\end{array}$ & $\begin{array}{l}\text { Neutra } \\
\text { I } 4 \text { (4) }\end{array}$ & $\begin{array}{l}\text { Moderatel } \\
y \\
\text { Important } \\
5(5)\end{array}$ & $\begin{array}{c}\text { Very } \\
\text { Importan } \\
\text { t } 6(6)\end{array}$ & $\begin{array}{l}\text { Extremel } \\
y \\
\text { Importan } \\
\text { t } 7 \text { (7) }\end{array}$ \\
\hline $\begin{array}{l}\text { 49. To what extent } \\
\text { is underwater } \\
\text { breath holding } \\
\text { dangerous? (1) }\end{array}$ & 0 & 0 & 0 & 0 & 0 & 0 & 0 \\
\hline $\begin{array}{c}50 . \text { What is } \\
\text { shallow water } \\
\text { blackout and to } \\
\text { what extent should } \\
\text { prevention efforts } \\
\text { attempt to reduce } \\
\text { the risk? (2) }\end{array}$ & 0 & 0 & 0 & 0 & 0 & 0 & 0 \\
\hline $\begin{array}{l}\text { 51. What can be } \\
\text { done to reduce } \\
\text { alcohol usage } \\
\text { around water? (3) }\end{array}$ & 0 & 0 & 0 & 0 & 0 & 0 & 0 \\
\hline $\begin{array}{l}\text { 52. What are the } \\
\text { psychological and } \\
\text { physiological } \\
\text { responses when a } \\
\text { person begins to } \\
\text { drown? (4) }\end{array}$ & 0 & 0 & 0 & 0 & 0 & 0 & 0 \\
\hline $\begin{array}{l}\text { 53. How can the } \\
\text { use of drowning } \\
\text { prevention and } \\
\text { water safety } \\
\text { technology } \\
\text { increase? (5) }\end{array}$ & 0 & 0 & 0 & 0 & 0 & 0 & 0 \\
\hline $\begin{array}{l}\text { 54. To what extent } \\
\text { are specific } \\
\text { variables (i.e. } \\
\text { supervision, drug } \\
\text { and alcohol use, } \\
\text { prior convictions, } \\
\text { conditions of } \\
\text { water, prevention } \\
\text { and rescue training, } \\
\text { time child was } \\
\text { missing) associated } \\
\text { with drowning? (6) }\end{array}$ & 0 & 0 & 0 & 0 & 0 & 0 & 0 \\
\hline
\end{tabular}




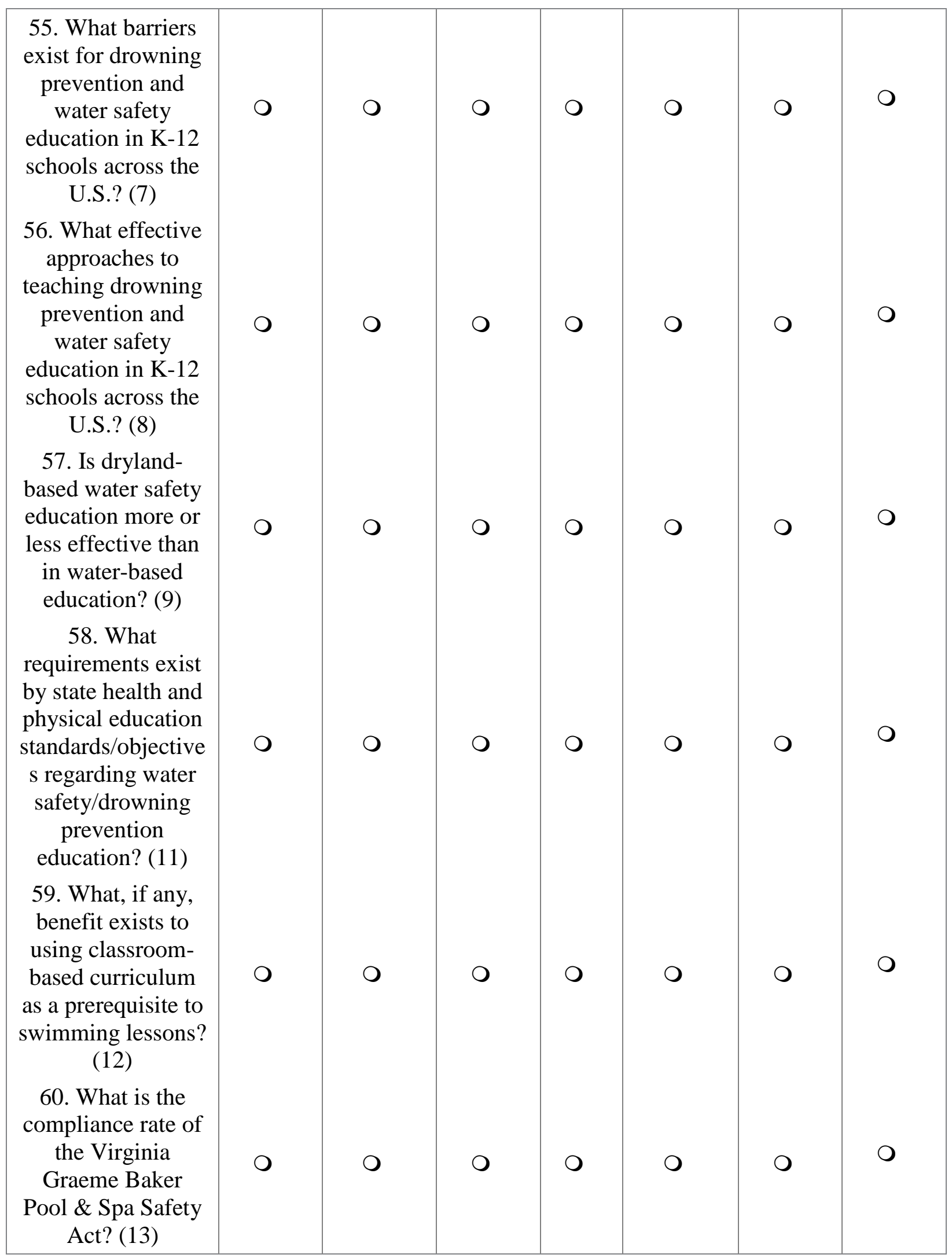




\begin{tabular}{|c|c|c|c|c|c|c|c|}
\hline $\begin{array}{l}\text { 61. What is the } \\
\text { impact of litigation } \\
\text { on the availability } \\
\text { and variety of } \\
\text { aquatics } \\
\text { programming? (14) } \\
\text { 62. Has there been } \\
\text { a significant } \\
\text { difference in the } \\
\text { number of } \\
\text { drownings in } \\
\text { California } \\
\text { before/after the } \\
\text { passing of the } \\
\text { Swimming Pool } \\
\text { Safety Law passed } \\
\text { in 1996? (15) } \\
\text { 63. To what extent } \\
\text { are parent/family } \\
\text { member } \\
\text { testimonials used } \\
\text { in developing } \\
\text { drowning policy } \\
\text { and legislative } \\
\text { efforts? (16) }\end{array}$ & 0 & 0 & 0 & 0 & 0 & 0 & 0 \\
\hline
\end{tabular}




\begin{tabular}{|c|c|c|c|c|c|c|c|}
\hline & $\begin{array}{c}\text { Not at all } \\
\text { importan } \\
\text { t } 1 \text { (1) }\end{array}$ & $\begin{array}{c}\text { Low } \\
\text { importanc } \\
\text { e } 2(2)\end{array}$ & $\begin{array}{l}\text { Slightly } \\
\text { Importan } \\
\text { t } 3 \text { (3) }\end{array}$ & $\begin{array}{l}\text { Neutra } \\
14(4)\end{array}$ & $\begin{array}{c}\text { Moderatel } \\
y \\
\text { Important } \\
5(5)\end{array}$ & $\begin{array}{c}\text { Very } \\
\text { Importan } \\
\text { t } 6(6)\end{array}$ & $\begin{array}{c}\text { Extremel } \\
y \\
\text { Importan } \\
\text { t } 7 \text { (7) }\end{array}$ \\
\hline $\begin{array}{l}\text { 64. What are the } \\
\text { most common } \\
\text { drowning/accident } \\
\text { s in aquatic } \\
\text { environments? (1) } \\
\text { 65. What aquatic } \\
\text { environments (i.e., } \\
\text { pool, spa, lake, } \\
\text { river, ocean) have } \\
\text { the greatest } \\
\text { number of aquatic } \\
\text { injuries/fatalities? } \\
\text { (2) } \\
\text { 66. In regards to } \\
\text { lightning, what is } \\
\text { a reasonable } \\
\text { policy in both an } \\
\text { outdoor and } \\
\text { indoor } \\
\text { environment? (3) } \\
\text { 67. Are current } \\
\text { regulations } \\
\text { surrounding } \\
\text { entrapment } \\
\text { prevention, } \\
\text { fencing } \\
\text { requirements, and } \\
\text { other similar } \\
\text { barriers effective } \\
\text { at reducing } \\
\text { drowning and } \\
\text { aquatic } \\
\text { injuries/fatalities? } \\
\text { (4) }\end{array}$ & 0 & 0 & 0 & 0 & 0 & 0 & 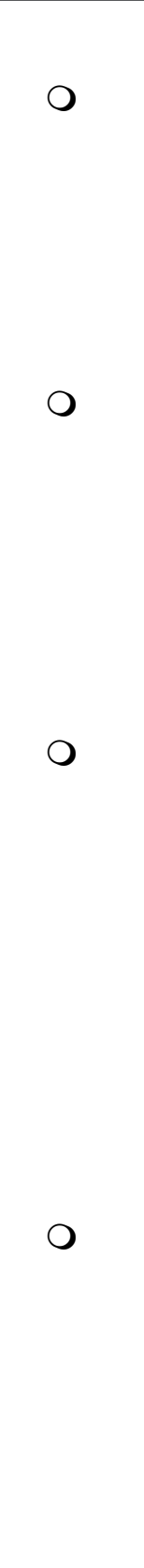 \\
\hline
\end{tabular}




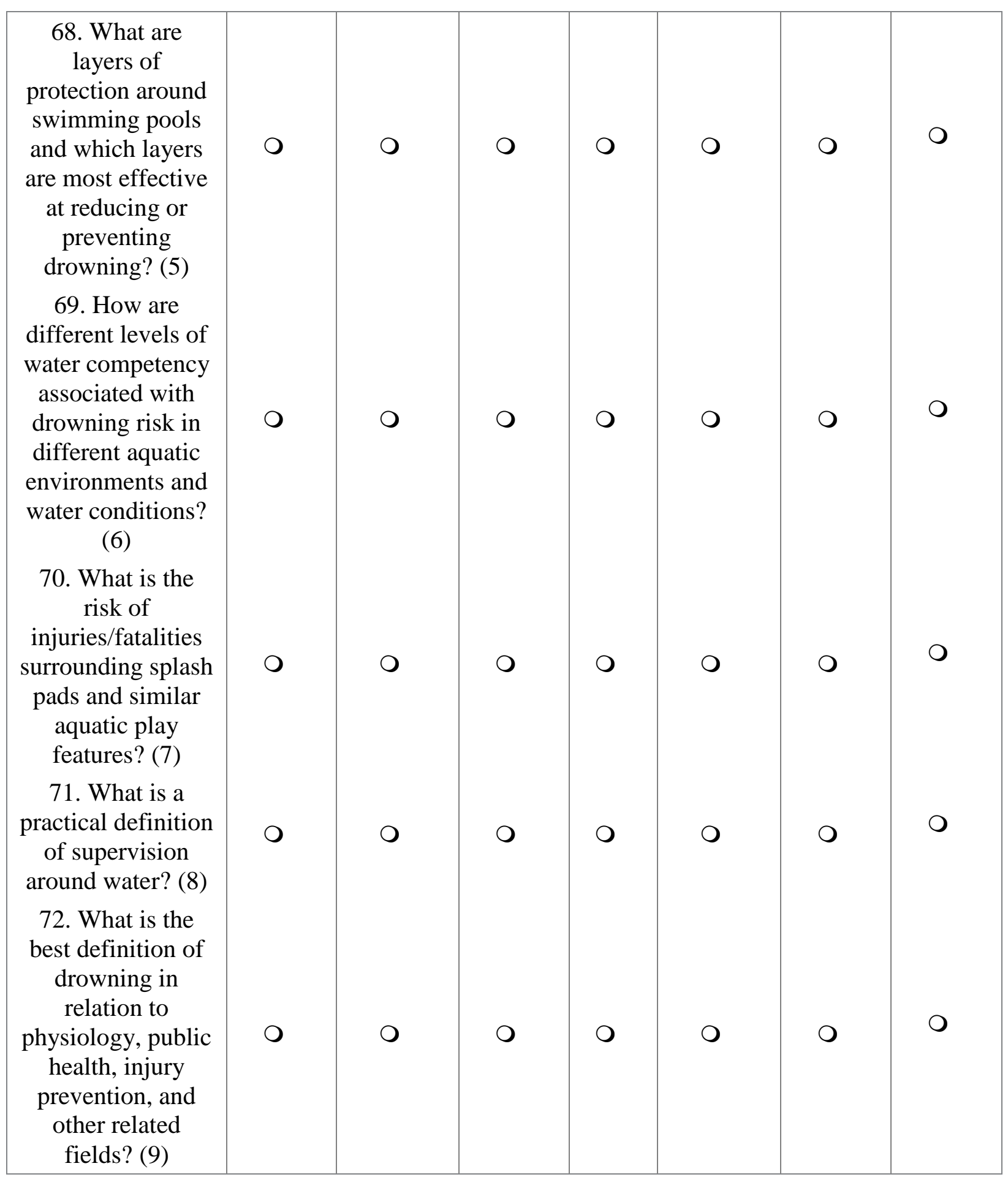




\begin{tabular}{|c|c|c|c|c|c|c|c|}
\hline $\begin{array}{c}\text { 73. What } \\
\text { percentage of the } \\
\text { U.S. population, } \\
\text { by age group, has } \\
\text { a basic } \\
\text { understanding of } \\
\text { water safety AND } \\
\text { water safety } \\
\text { skills? (10) }\end{array}$ & 0 & 0 & 0 & 0 & 0 & 0 & 0 \\
\hline
\end{tabular}




\begin{tabular}{|c|c|c|c|c|c|c|c|}
\hline & $\begin{array}{l}\text { Not at all } \\
\text { importan } \\
\text { t } 1 \text { (1) }\end{array}$ & $\begin{array}{c}\text { Low } \\
\text { importanc } \\
\text { e } 2 \text { (2) }\end{array}$ & $\begin{array}{l}\text { Slightly } \\
\text { Importan } \\
\text { t } 3 \text { (3) }\end{array}$ & $\begin{array}{l}\text { Neutra } \\
\text { I } 4 \text { (4) }\end{array}$ & $\begin{array}{c}\text { Moderatel } \\
y \\
\text { Important } \\
5(5)\end{array}$ & $\begin{array}{c}\text { Very } \\
\text { Importan } \\
\text { t } 6(6)\end{array}$ & $\begin{array}{c}\text { Extremel } \\
y \\
\text { Importan } \\
\text { t } 7 \text { (7) }\end{array}$ \\
\hline $\begin{array}{l}\text { 74. What drowning } \\
\text { prevention education } \\
\text { initiatives/strategies } \\
\text { can effectively focus } \\
\text { on diverse } \\
\text { populations? }(1)\end{array}$ & 0 & 0 & 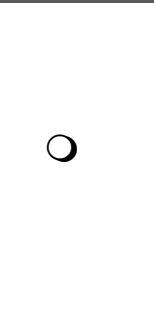 & 0 & 0 & 0 & 0 \\
\hline $\begin{array}{l}\text { 75. What drowning } \\
\text { prevention education } \\
\text { initiatives/strategies } \\
\text { can effectively focus } \\
\text { on adults? (2) }\end{array}$ & 0 & 0 & 0 & 0 & 0 & 0 & 0 \\
\hline $\begin{array}{c}\text { 76. How are } \\
\text { neurological } \\
\text { development and risk } \\
\text { taking behavior } \\
\text { factors } \\
\text { addressed/incorporat } \\
\text { ed in drowning } \\
\text { prevention education } \\
\text { for adolescents and } \\
\text { young adults? (3) }\end{array}$ & 0 & 0 & 0 & 0 & 0 & 0 & 0 \\
\hline $\begin{array}{l}\text { 77. What factors } \\
\text { contribute to } \\
\text { minority and low } \\
\text { income children } \\
\text { drowning rates } \\
\text { compared to same } \\
\text { aged peers? (4) }\end{array}$ & 0 & 0 & 0 & 0 & 0 & 0 & 0 \\
\hline $\begin{array}{l}\text { 78. To what extent } \\
\text { do specific cultural } \\
\text { issues impact the } \\
\text { effectiveness of } \\
\text { drowning prevention } \\
\text { education and the use } \\
\text { of safe practices? (5) }\end{array}$ & 0 & 0 & 0 & 0 & 0 & 0 & 0 \\
\hline
\end{tabular}




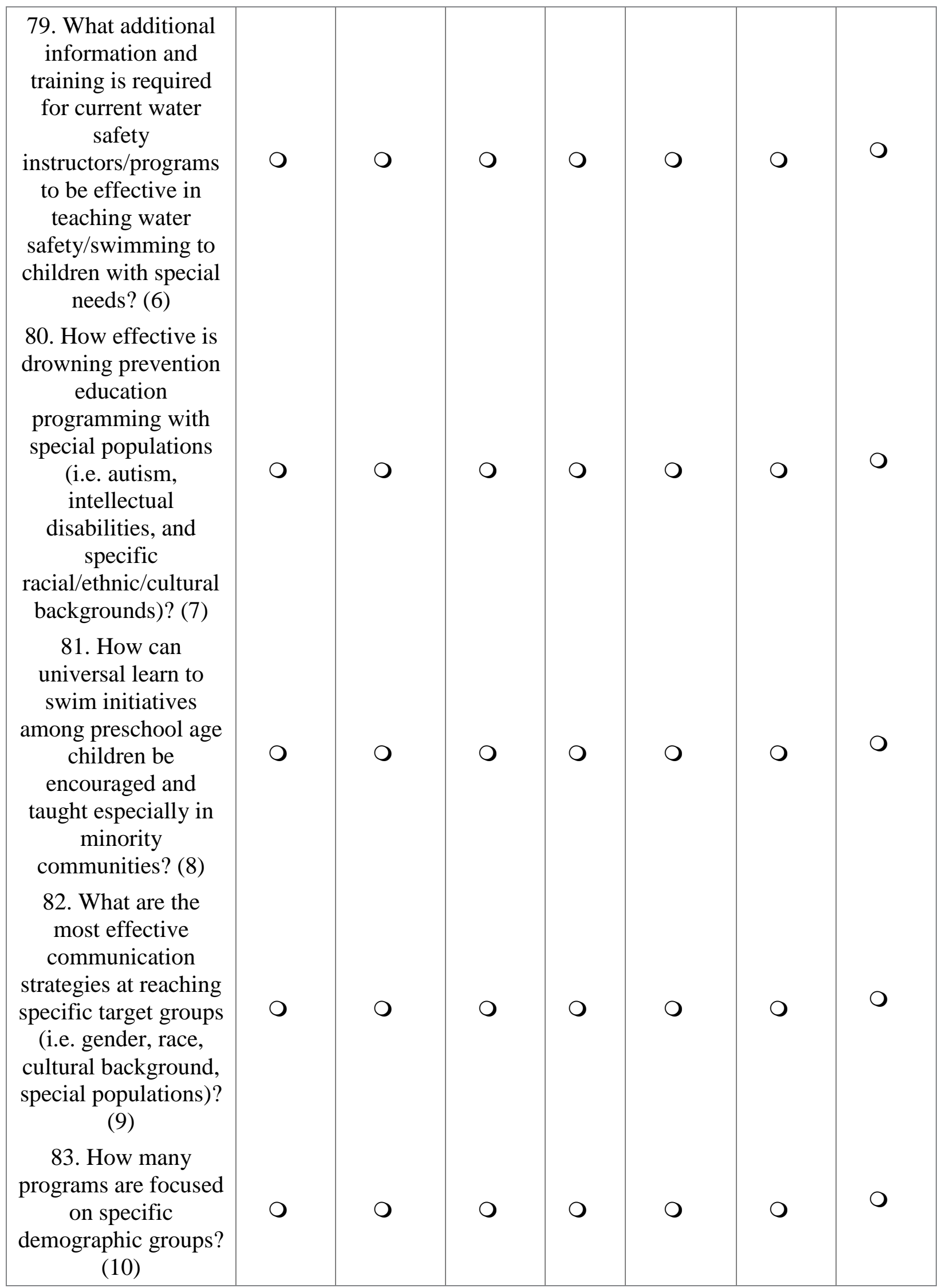




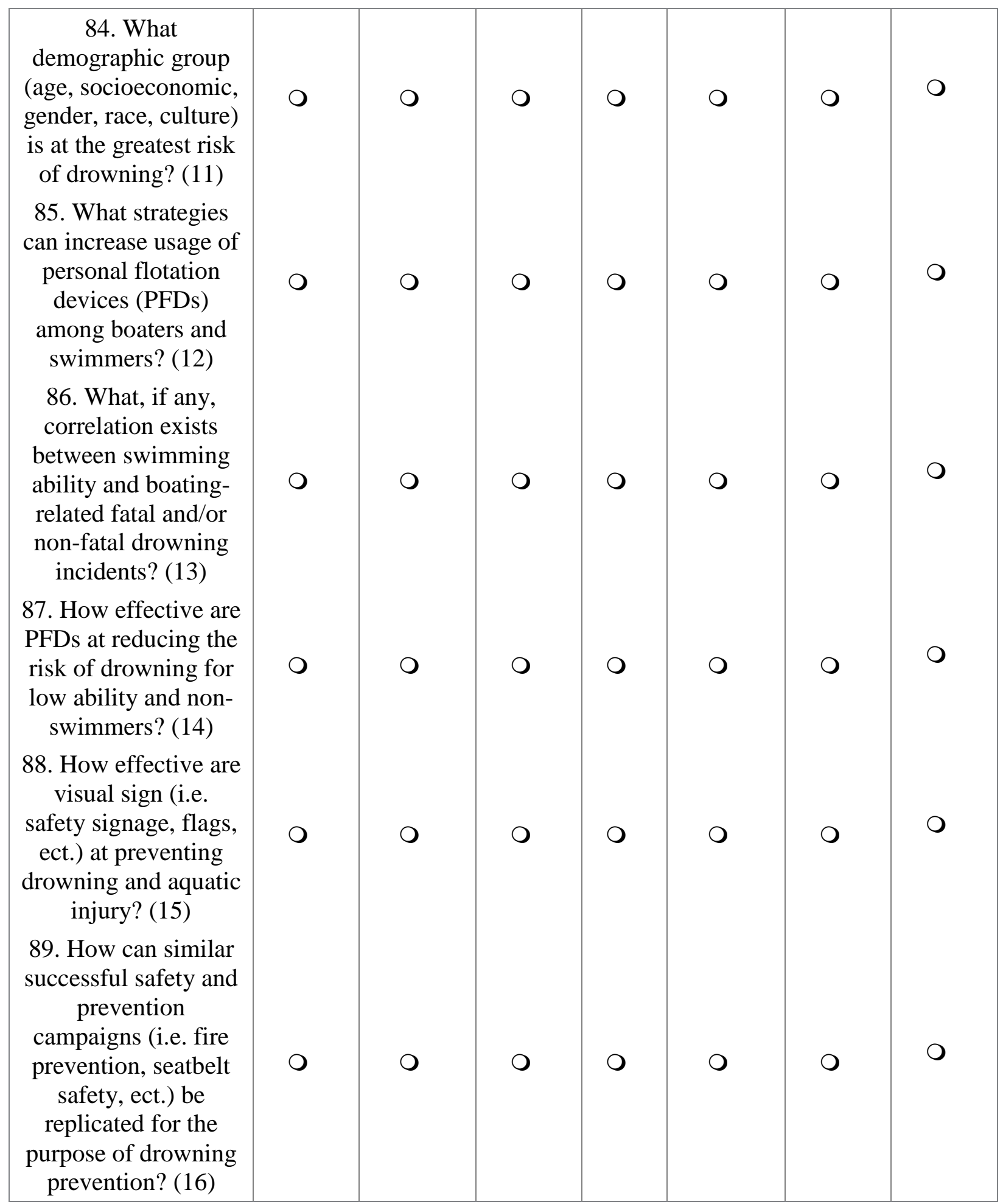




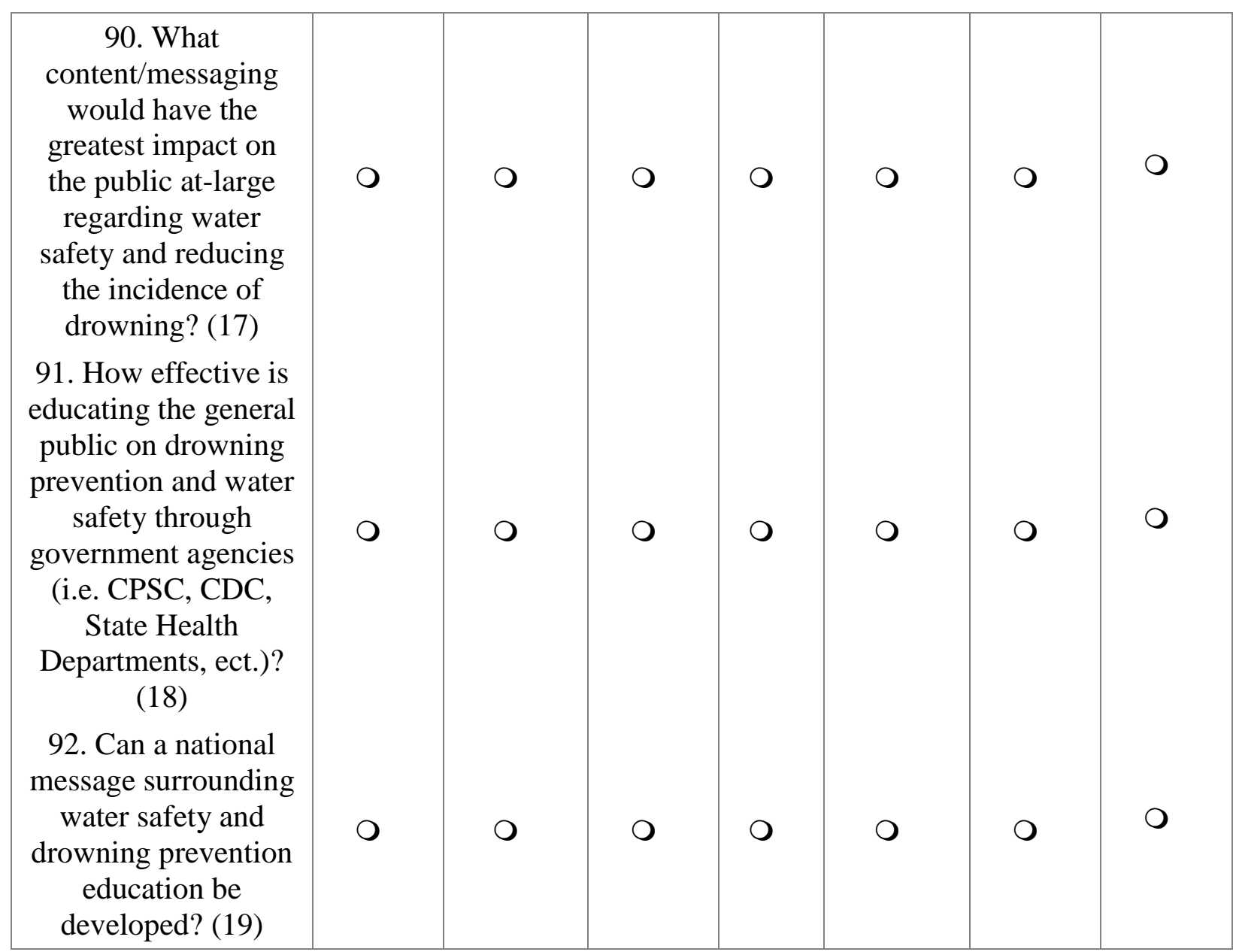

